UNIVERSIDADE DE SÃO PAULO

ESCOLA DE COMUNICAÇÕES E ARTES

DEPARTAMENTO DE MÚSICA

\title{
A POÉTICA JAPONESA NA CANÇÃO BRASILEIRA
}

MARIA YUKA DE ALMEIDA PRADO

São Paulo

2009 


\section{A POÉTICA JAPONESA NA CANÇÃO BRASILEIRA}

Tese apresentada ao Departamento de Música da Escola de Comunicações e Artes da Universidade de São Paulo, como exigência parcial para obtenção do Título de Doutor em Musicologia.

Área de Concentração: Musicologia

Orientador: Prof. Dr. Rubens Russomano Ricciardi 
AUTORIZO A REPRODUÇÃO E DIVULGAÇÃO TOTAL OU PARCIAL DESTE TRABALHO, POR QUALQUER MEIO CONVENCIONAL OU ELETRÔNICO, PARA FINS DE ESTUDO E PESQUISA, DESDE QUE CITADA A FONTE.

FICHA CATALOGRÁFICA

Prado, Maria Yuka de Almeida

A poética japonesa na canção brasileira. Ribeirão Preto, 2009.

138p.: il.; $30 \mathrm{~cm}$

Tese de Doutorado, apresentada ao Departamento de Música da Escola de Comunicações e Artes da Universidade de São Paulo.

Área de Concentração: Musicologia.

Orientador: Ricciardi, Rubens Russomano

1. canção; 2. análise musical; 3. Japonisme; 4. Villa-Lobos; 5. Gilberto Mendes; 6. Luiz Carlos Lessa Vinholes; 7. José Antônio de Almeida Prado; 8. Rodolfo Coelho de Souza. 
Prado, M.Y.A. A poética japonesa na canção brasileira. Tese apresentada ao Departamento de Música da Escola de Comunicações e Artes da Universidade de São Paulo. 2009.

Aprovado em:

\section{Banca Examinadora}

Prof. Dr.

Assinatura:

Prof. Dr.

Assinatura:

Prof. Dr.

Assinatura:

Prof. Dr.

Assinatura:

Prof. Dr.

Assinatura: 


\section{DEDICATÓRIA}

Ao querido marido Sebastião, pelo amor sem fim. 
Conhecer a si mesmo é ter um conhecimento lúcido do nível do grau de sua arte, pois quando "se conscientizar exatamente do nível de seu próprio grau, a flor que corresponde a esse nível não mais desaparecerá por toda a vida. Quando se acredita que é hábil além deste grau, a flor que corresponde ao grau anteriormente atingido desaparece" [Omote e Kato]. $\mathcal{A}$ avaliação do nivel de seu grau de arte deve ser permanente. Mesmo aquele que atingiu o mais alto nivel deve estar em constante prova, porque nenfum mestre pode resistir ao assalto dos anos (Motokyo Zeami apud GIROUX, 1991, p. 108). 


\section{AGRADECIMENTOS}

Final do espetáculo. Agradecemos. O solista é o centro das atrações, mas ele só representa o resultado de um trabalho em conjunto: o maestro, a orquestra, o mis-enscène, o cenógrafo, o figurinista, o maquiador, o iluminador, o empresário, enfim, somente para mencionar alguns. Às vezes, os apoios ocultos são os mais relevantes.

Ao meu orientador, Rubens Russomano Ricciardi, o maestro (apesar de não gostar de ser assim chamado) de todo este espetáculo, por toda dedicação e empenho para transformar um projeto em realidade.

Ao Rodolfo Coelho de Souza, pela luz que foi me fornecendo ao longo do trabalho, tanto como professor, como colega e, principalmente como compositor.

Ao Juarez Ramalho Pinto, como mis-en-scène, que me conduz à compreensão e ao entusiasmo nos caminhos do trabalho científico.

Aos compositores Gilberto Mendes e Luis Carlos Lessa Vinholes, pela oportunidade do diálogo com o criador.

Às Fátima Corvisier, Eliana Sulpício e Silvia Berg, pelas exaustivas horas de ensaios e execução das obras em inúmeros concertos.

À Adriana Giarola Kayama, pelas valiosas informações sobre a obra de Almeida Prado.

À Lilian de Aguiar Ricz, pelas infindáveis parcerias no estudo da voz.

À Myriam Vianna, pelas investigações em torno das emoções que envolvem a voz.

Ao meu irmão Marcelo Yukio e sua esposa Roberta, pelas leituras do texto.

Às Fernanda e Cecília Onofre, pelos variados suportes logísticos e operacionais.

Ao Bruno Moreira da Costa e Humberto Dias Correia, pelas edições das partituras. 
Às minhas mestras de canto, Marta Herr, Leilah Farah (in memoriam), Sachie Nakayama, Nori Takemura e Edmar Ferretti.

À Fundação Japão, pela doação de livros sobre a cultura japonesa à biblioteca do campus de Ribeirão Preto.

À Yuko Maeda e ao Pe. João Manoel Lima Mira, s.j., pelo encontro mais profundo e sólido com a cultura japonesa.

Ao Pedro Paulo Ortolan, fiel companheiro dantesco, pelos devaneios, turbulências, afeto, silêncio e criatividade.

À Melody Chapin, pelo novo despertar que me fez deslumbrar na canção brasileira.

Aos meus alunos, pelo sentido do meu trabalho.

Aos meus pais, pelo o que sou. 


\section{LISTA DE FIGURAS}


Figura 1: Compassos 9 e 13 de O meu amigo Koellreutter (Gilberto Mendes) ....36

Figura 2: Compasso 9 a 12 de $O$ meu amigo Koellreutter (Gilberto Mendes)......37

Figura 3: Pluie soudane sur le pont d’Ataka (Utagawa Hiroshigue), 1857 [p.45] . 45

Figura 4: Pont sur la pluie (Vincent Van Gogh), 1887 [p.45] 45

Figura 5: Dans le jardins du sanctuaire Tenjin, Kameido (Utagawa Hiroshigue), 1857. [p.194]...

Figura 6: Le Bassin aux nymphéas (Claude Monet), 1899 46

Figura 7: La Grande Vague (Hokusai), 31[p.59]. 48

Figura 8: Jaquette de La Mer de Debussy Adaptation de La Grande Vague (Hokusai), 1905 [p.151]

Figura 9: La Japonaise (Claude Monet), 1876 [p.111] 49

Figura 10: La Japonaise (Hans Makart), 1875 [p.125] 49

Figura 11: The Geisha (Dudley Hardy), 1896. 51

Figura 12: Madama Butterfly, 1904 51

Figura 13: Compassos 1, 2, 24 e 25 de Japonêsas (Villa-Lobos)....... 53

Figura 14: Compassos 6, 7 e 8 de Japonêsas (Villa-Lobos). 54

Figura 15: Compassos 12 a 15 de Japonêsas (Villa-Lobos). 55

Figura 16: Compassos 20 a 24 de Japonêsas (Villa-Lobos) 56

Figura 17: Vinholes e Shūzo Iwamoto. 75

Figura 18: Vinholes com as crianças da Escola Primária Ōtani Shōgakkō ..........76

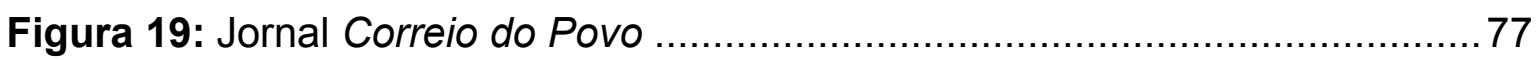

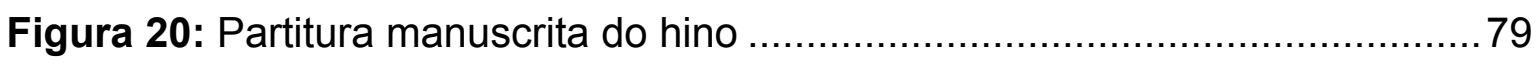

Figura 21: Escala da Canção folclórica ("castas inferiores”) 83 
Figura 22: Escala Ryō do Gagaku (“música da corte”) ................................. 83

Figura 23: Escala Ritsu do Gagaku (“música da corte”) ............................... 83

Figura 24: Escala do Miyako-bushi ("samurai urbano" - e esse é o caso do famoso Sakura, Sakura).

Figura 25: Escala de Okinawa ("uma província ao sul do Japão - regional”) ........83

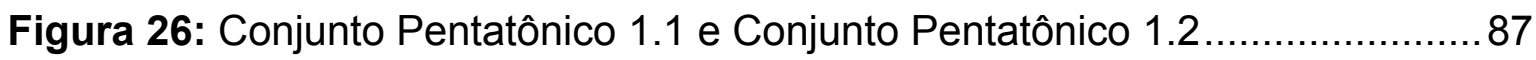

Figura 27: Os conjuntos pentatônicos transpostos ................................... 87

Figura 28: Escala Ryō do Gagaku ("música da corte") - [2,2,3,2] ..................... 87

Figura 29: Notas musicais de todos os compassos da primeira canção de Cinco Canções Japonesas (Rodolfo Coelho de Souza) ................... 88

Figura 30: Unidades melódicas da primeira canção de Cinco Canções Japonesas (Rodolfo Coelho de Souza) .................................... 89

Figura 31: Os dois conjuntos pentatônicos da melodia da primeira canção de Cinco Canções Japonesas (Rodolfo Coelho de Souza)....

Figura 32: Conjunto Pentatônico 2.1 e Conjunto Pentatônico 2.2 da segunda canção de Cinco Canções Japonesas (Rodolfo Coelho de Souza)...90

Figura 33: Os conjuntos pentatônicos transpostos 90

Figura 34: Escala da Canção folclórica ("castas inferiores") - [3,2,2,3] e Escala Ryō do Gagaku ("música da corte") - [2,2,3,2].

Figura 35: As notas musicais de todos os compassos da segunda canção de Cinco Canções Japonesas (Rodolfo Coelho de Souza).

Figura 36: Unidades melódicas da segunda canção de Cinco Canções Japonesas (Rodolfo Coelho de Souza).

Figura 37: As notas da linha melódica da mesma canção, ordenadas da nota mais grave para a mais aguda seguindo uma sequência cromática como fusão dos dois conjuntos pentatônicos.

Figura 38: Linha melódica da canção 3, 4 e 5 de Cinco Canções Japonesas (Rodolfo Coelho de Souza) que, se ordenadas, formam a série cromática

Figura 39: Escalas pentatônicas Diatônica, Pelog, Hirajoshi e Kumoi 100 
Figura 40: Cinco formas modais do pentatônico diatônico transpostas para a mesma tônica para comparação...................................................... 101

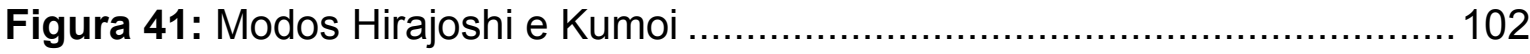

Figura 42: Compassos 1 e 2 de Acalanto para Noemi (Almeida Prado) ..............103

Figura 43: Compassos 28 a 31 de Acalanto para Noemi (Almeida Prado) ........ 104

Figura 44: Compassos 3 a 5 de Acalanto para Noemi (Almeida Prado) ............ 105 
RESUMO

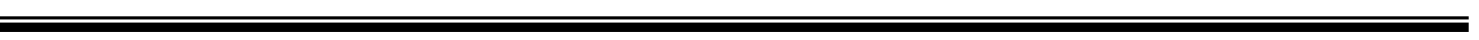


PRADO, M.Y.A. A poética japonesa na canção brasileira. 138f. Tese (Doutorado) - Escola de Comunicações e Artes, Universidade de São Paulo, São Paulo, 2009.

O cantor deve conhecer em profundidade a obra a ser executada, além de dominar o seu instrumento - a voz. Assim, este estudo foi baseado na análise de obras de Heitor Villa-Lobos (1887-1959), Gilberto Mendes (1922), Luiz Carlos Lessa Vinholes (1933), José Antonio de Almeida Prado (1943) e Rodolfo Coelho de Souza (1952), sob a ótica do intérprete artista, ou seja, do autor. As obras refletem o amálgama da miscigenação de várias culturas que compõem a nação brasileira. Através deste repertório, questionou-se por que compositores brasileiros compuseram canções com a temática japonesa e como ocorre o encontro da poética japonesa com a canção brasileira. A análise musical foi, em sua maioria, baseada no livro Poetry into song: performance and analysis of Lieder de Deborah Stein \& Robert Spillman. Constatou-se a presença de uma esfera meditativa pelo uso de estruturas minimalistas e pentatonismos. De acordo com o autor, isto se deve pela busca do vazio e do silêncio enquanto criação musical. São, portanto, frutos da necessidade intrínseca de uma época - o Zeitgeist - ou seja, experimentações em busca de novas linguagens como tendências da música do século $X X$. Considerando a peculiaridade do cantor como músico, apresentamos com o título de "Transcendência" nossa visão do papel do intérprete do canto. É preciso transcender todo o conhecimento analítico para a execução musical a fim de sentir a canção. Pois é justamente com o sentir e as vivências entre o compositor, poeta e intérprete; Brasil e Japão; racional e afetivo; mundo interno e externo; análise e performance que as bordas fictícias ou imaginadas são atenuadas.

Palavras-chave: canção, análise musical, Japonisme, Villa-Lobos, Gilberto Mendes, Luiz Carlos Lessa Vinholes, José Antônio de Almeida Prado, Rodolfo Coelho de Souza. 
PRADO, M.Y.A. Japanese poetics in Brazilian art song. 138f. Thesis (Doctoral) - Escola de Comunicações e Artes, Universidade de São Paulo, São Paulo, 2009.

The singer must deeply understand the work to be interpreted and, in addition to this, he must dominate his instrument - the voice. Accordingly, this study is based on the analysis of works by Heitor Villa-Lobos (1887-1959), Gilberto Mendes (1922), Luiz Carlos Lessa Vinholes (1933), José Antônio de Almeida Prado (1943) and Rodolfo Coelho de Souza (1952), from the point of view of the artistic interpreter, the author. The art songs chosen reflect a cultural mosaic specific to Brazil. Through this repertoire, the author questioned why Brazilian composers chose a Japanese subject for their songs and how they integrated Japanese characteristics into Brazilian art song. This musical analysis was mainly based on the book Poetry into song: performance and analysis of Lieder by Deborah Stein \& Robert Spillman. The author observed a presence of meditative atmosphere through the use of minimalist structure and pentatonicism. She believes this was the composers' quest for emptiness and silence while still creating music. These are, therefore, the fruits of an era: the Zeitgeist, the experiments in a search for new languages, a tendency of 20th Century music. Considering the peculiarity of the singer as a musician, the author presents in a summarizing chapter, "Transcendency", what she believes the role of an artistic interpreter should express. The singer must transcend the analytical knowledge he has acquired prior to performance in order to know the song. Only then do the feeling and existence of the composer, the poet, the interpreter; Brazil and Japan; reason and emotion; inner and outer world; and analysis and performance integrate, and only then is the fictitious or imagined border blurred.

Key words: art song, musical analysis, Japonisme, Villa-Lobos, Gilberto Mendes, Luiz Carlos Lessa Vinholes, José Antônio de Almeida Prado, Rodolfo Coelho de Souza. 
A busca pelo sentido do ser e da existência é o fundamento deste trabalho. Nasci com certa estranheza. Eu era diferente e cresci me perguntando qual seria a razão. Eis que procurei resgatar minhas origens num encontro com minha própria voz. Estudando canto no Japão, onde permaneci por sete anos, vivenciei contradições culturais num processo de fusão de horizontes.

Esta pesquisa é um prolongamento desse meu caminhar incessante, através do canto que se processa numa interação indissociável entre Brasil e Japão, ocidente e oriente, mundo interno e externo, racionalidade e emoções, análise e performance. Portanto, é em torno dessas bordas fictícias que redijo minha tese.

Nosso estudo contempla análises de obras musicais e seus entornos tendo em vista a execução musical (prática interpretativa) - meu ofício de cantora. Não pretendo abordar a questão da voz enquanto instrumento musical que requer um estudo disciplinado, uma preparação física do corpo como um todo, ou ainda um amadurecimento psicológico para controlar as emoções; muito menos se trata de um manual de interpretação vocal. Procuramos, assim, trabalhar a voz tão-somente enquanto meio de expressão a serviço da criação musical sob a visão de um intérprete.

Este trabalho é um meio para um fim. O fim é a execução das obras pesquisadas. O meio é a degustação da obra: a leitura musical, a decifração do sentido oculto atrás das partituras, a intenção do compositor e o sentido de sua existência como canção brasileira. Para o cantor, todos estes resultados de investigação são fundamentais em um processo empírico interno que se concretiza tão somente na execução. Portanto, dialogar em profundidade com estas canções proporciona um enriquecimento oculto na esfera da voz interna que se reproduz ampliando a reverberação da voz externa. Esta voz, resultado da fusão de inúmeros horizontes, ecoa em dimensões invisíveis, mas pode ser ouvida somente aos sentidos de quem a escuta. 
Não obstante a imprescindível fidelidade para com a partitura - uma vez que o compositor já indica, de algum modo, o contexto interpretativo - as interpretações no palco extrapolam as intenções contidas nas fontes elaboradas pelo compositor. Neste trabalho, as interpretações do sentido da obra também extrapolam, muitas vezes, as intenções ocultas do compositor.

Uma tese pode provocar algo como a regurgitação de nossas entranhas, o que nos faz sentir até uma autopiedade desviando, assim, de nossos caminhos pré-concebidos. Mas é justamente nesses descaminhos que vislumbro uma reflexão crítica enriquecedora do percurso.

E como viabilizar a redação de uma tese acadêmica sobre a canção brasileira? Como descrever o indizível da música, se aqui estamos restritos ao texto escrito? Já há muito não se leva mais em consideração a velha unidade

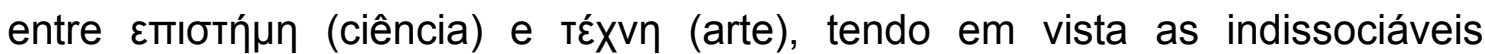
relações entre teoria e prática. Mas, de fato, tanto na arte como na ciência, são essenciais, tanto o caráter especulativo como operativo, a análise e a realização, a observação e o experimento. Incorporando essas questões percorri os sinuosos caminhos na construção dessa tese. O antropólogo Cliffort Geertz afirma que "se você quer compreender o que é a ciência, você deve olhar, em primeiro lugar, não para as suas teorias ou suas descobertas, e certamente não para o que seus apologistas dizem sobre ela; você deve ver o que os praticantes da ciência fazem" (GEERTZ, 1989, p. 15).

Essa questão me remete à vivência na relação mestre-discípulo no aprendizado do canto durante os anos vividos no Japão. Sinto-me privilegiada de ter tido essa rica experiência tão autêntica e que reverbera em meus atos. Nascida e crescida na sociedade brasileira de raízes escravocratas fui, posteriormente, trabalhar justamente "feito uma escrava" para minha mestra Nori Takemura. Assumir tarefas caseiras de faxinas no alvorecer (mesmo no inverno com fortes nevascas): cozinhar, lavar pratos, fazer compras, organizar a casa e ainda cuidar da yorkshire branquinha (ela se chamava Laurie e usava botinhas vermelhas para passear!). Fora isso, havia que se pagar, tanto a estada como as aulas. Esse tipo de relação era algo revoltante na minha 
perspectiva cultural. Entretanto, aos poucos fui descobrindo o profundo aprendizado na convivência diária com a mestra. Ela me dizia que o segredo era aprender como ela própria vivia: o que comia, como comia, o que fazia, como se organizava, como trabalhava, como relaxava. E isso só se aprenderia servindo-a desde bem cedo até tarde da noite. Assim aprendi a realizar um trabalho com alto rendimento num período restrito, geralmente não mais que uma hora, pois mal me sobrava tempo para o estudo do canto. Em sua sabedoria: "a sensibilidade estética começa pelo paladar: o artista deve comer não só alimentos bons e saudáveis, e mais que isso, a comida tem que ter, além de sabor refinado, um requinte nos cinco sentidos". Em sua rica mansão, caracteristicamente nipônica, praticava-se semanalmente a arte da cerimônia do chá (chadō), a arte do arranjo de flores (kadō ou ikebana), a arte da caligrafia (shodō), a arte da pintura a carvão (sumiê) e a arte do poema (haiku). Esses eram apenas ornamentos em torno da arte do canto.

Nesse novo cotidiano, assimilei dietas nobres com peixes, verduras, legumes e ervas raras. Foram anos de rigorosa disciplina, submissão, resignação, tolerância, paciência e de muito trabalho. Só desse modo consegui domar meus impulsos para caminhar sem abandonar o caminho, sendo como uma montanha de pedra, ou seja, manter-me intacta, faça sol, chuva, tempestades ou ventos fortes. A arte de viver era mais importante que a arte do canto, expresso no seu princípio fundamental: "não sei se poderei te transformar numa cantora, mas eu vou fazer você virar gente", ou ainda, "não queira ser a rosa vermelha se você é uma flor do campo, mas que seja a flor mais bela do campo".

Esta tese é um ensaio que tem como proposta o redimensionamento da fusão de horizontes das culturas ocidental e oriental através da canção de compositores brasileiros com a poética japonesa. Ela se constitui numa tentativa de abranger a arte do pensar, a arte do selecionar, a arte do elaborar, a arte do ser, a arte do deixar ser, a arte do ser outra coisa, a arte do desejar, a arte do querer, a arte do sentir, a arte do morrer e a arte do viver de forma coerente e integrada. 


\section{SUMÁRIO}

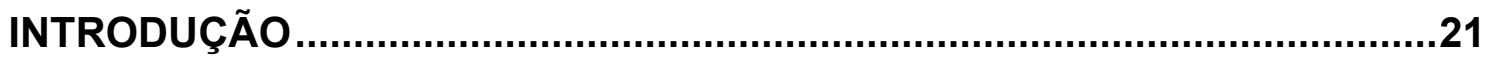

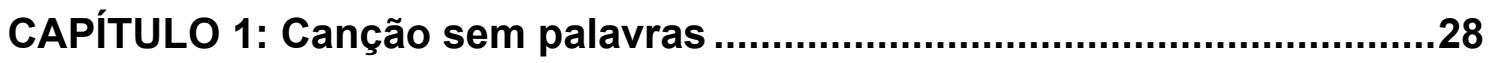

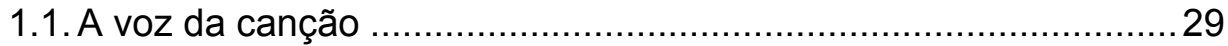

1.2. O meu amigo Koellreutter de Gilberto Mendes..............................31

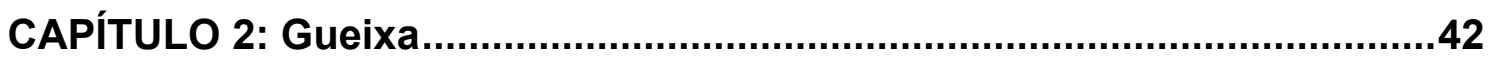

2.1. O movimento Japonisme .......................................................... 44

2.2. Japonêsas de Heitor Villa-Lobos ..............................................51

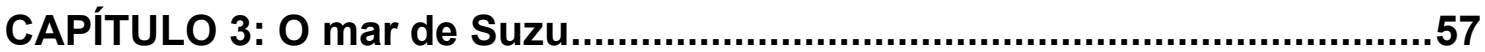

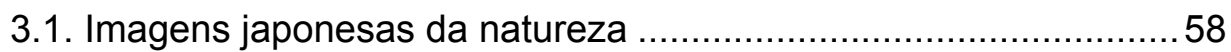

3.2. O Movimento da poesia concreta ...............................................63

3.3. Ōtani Shōgakkō Ka de Luiz Carlos Lessa Vinholes ...................... 66

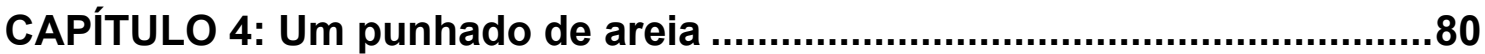

4.1. As classes sociais e o pentatonismo .............................................81

4.2. Cinco Canções Japonesas de Rodolfo Coelho de Souza............. 84

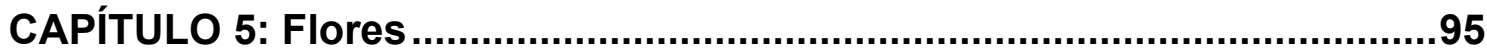

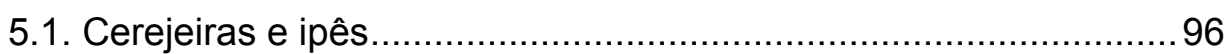

5.2. Acalanto para Noemi de José Antônio de Almeida Prado............... 99

CONSIDERAÇÕES FINAIS ...................................................................107

REFERÊNCIAS BIBLIOGRÁFICAS...................................................110

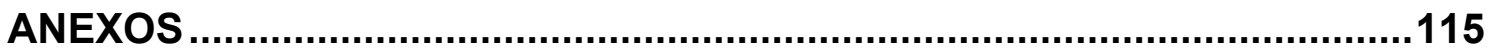


Você quer o que deseja? Eis o título instigante de um livro de Jorge Forbes. Segundo esse psicanalista lacaniano, a pergunta "revela que nada que alguém possa querer é suficiente para satisfazer o desejo. Desejar é sempre desejar outra coisa, a ponto de podermos agradecer a quem não nos dá o que foi pedido" (FORBES, 2004, p. 7). Desejar tem um aspecto mais instintivo de volúpia, de impulsos, enquanto o querer se enquadra no plano do possível de realização. São essas duas forças que regem nossas escolhas, uma se sobrepondo à outra ou ambas se interagindo até se equilibrarem.

Afinal, o que desejo e quero com esta tese? É uma busca incessante, interminável... de quais questões escolher. As perguntas estão devidamente pautadas, são pontuais. Mas o que eu desejo é realmente o que quero? Esta é uma resposta inalcançável: vita brevis, ars longa.

Talvez, por isso, a tese nunca alcance uma elaboração a contento. Você quer o que deseja? - "fala da angústia própria à escolha. Não há escolha que não seja arriscada e que não induza à perda" (FORBES, 2004, p. 8). A elaboração da tese, dessa forma, é uma luta constante, com perdas. É um deixar de ser que angustia com cada tomada de decisão.

O objetivo da tese, portanto, não é responder definitivamente às perguntas, mas organizar as questões de tal forma que ela não se encerre em si mesma. Quanto mais caminhos ela abrir, mais frutífera será no porvir. E aqui cabe a pergunta: por que tantos compositores brasileiros do século $X X$ compuseram canções com a temática japonesa? Como ocorre a inserção da poética japonesa na canção brasileira?

Assim, após algumas perdas, chego finalmente ao título desta tese: $A$ poética japonesa na canção brasileira. Esse título foi inspirado no livro Poetry into Song de Deborah Stein e Robert Spillman, contemplando análises para a performance do gênero lied. Boa parte das análises apresentadas nesta tese remonta a essa obra referencial. 
Em seu livro Os problemas da estética, Luigi Pareyson define o conceito de poética por seu caráter programático e operativo (atividade artística), enquanto a estética tem um caráter analítico e especulativo (atividade filosófica). E acrescenta: "uma poética é eficaz somente se adere à espiritualidade do artista e traduz seu gosto em termos normativos e operativos, o que explica como uma poética está ligada ao seu tempo, pois somente nele se realiza aquela aderência e, por isso, se opera aquela eficácia" (PAREYSON, 1997, p. 15). Por outro lado, Pareyson diferencia ainda os conceitos de assunto e tema: se o assunto é o "argumento tratado", já o tema é o "motivo inspirador" (op. cit. p. 69). Nesse mesmo contexto, as canções com temática japonesa - compostas por compositores brasileiros - configuram-se como assunto desta tese. Assim, foram selecionadas canções de compositores brasileiros do século XX:

1) Japonêsas de Heitor Villa-Lobos (1887-1959);

2) O meu amigo Koellreutter de Gilberto Mendes (1922);

3) Ōtani Shōgakkō Ka de Luiz Carlos Lessa Vinholes (1933);

4) Cinco Canções Japonesas de Rodolfo Coelho de Souza (1952);

5) Acalanto para Noemi de José Antonio de Almeida Prado (1943).

Cabe mencionar que cada obra mereceria uma tese em si, considerando-se que cada compositor tem sua relevância particular no cenário musical brasileiro. Ainda como parte das "perdas", ao elaborarmos a tese optamos por remover a biografia de cada compositor, apesar de que, segundo Pareyson, "não é possível compreender a fundo a arte de um autor sem dar-se conta do que foi, para ele, a sua arte" (op. cit. p. 95). Parte da biografia dos compositores será mencionada, se necessário, para a compreensão da obra, respondendo justamente à questão: porque tantos compositores brasileiros compuseram canções com a temática japonesa? 
O motivo inspirador é essa fusão de horizontes da temática japonesa com a canção brasileira. A expressão fusão de horizontes (Horizontverschmelzung) é assim definida por Paul Ricoeur tendo Hans-Georg Gadamer como referência: "não existimos nem em horizontes fechados nem num único horizonte. Não há horizonte fechado, pois podemos nos transportar para outro ponto de vista e para outra cultura" (RICOEUR, 1990, p. 115). Com essa premissa é que perguntamo-nos: como ocorre a fusão da poética japonesa com a canção brasileira? Em uma mesma esfera se fundem Brasil e Japão, ocidente e oriente, compositor e poeta, criador e intérprete, análise e performance. Acreditamos que seja essencial para o intérprete de uma canção elaborar internamente essa fusão de vozes, do poeta, do compositor, e, acima de tudo, do próprio mundo da obra, pois, de fato, "o que deve ser interpretado num texto é uma proposição de mundo, de um mundo tal como posso habitá-lo para nele projetar um de meus possíveis mais próprios" (op. cit. p. 56). Trata-se do texto no contexto. É claro que Ricoeur tem em mente a exposição de um mundo pela obra de arte num sentido heideggeriano. Esse mundo não pertence à linguagem cotidiana nem à cultura, pois se trata antes da singularidade solitária da obra de arte. Assim, não abordamos aqui hipóteses antropológicas nem culturalistas, muito menos buscamos qualquer suposta identidade cultural em processos metafísicos ou de construção de “comunidades imaginadas" (expressão-título do livro de ANDERSON, 2008). Nem ao menos separamos orientais de ocidentais como se vivessem em "aquários humanos", pois justamente o que nos interessa é essa incontornável "promiscuidade cultural" - expressões recentes elaboradas por Luiz Felipe Pondé (2009).

Mas, voltando às questões de nossa tese, os capítulos foram estruturados aglomerando-se um sentido temático dos poemas para cada autor. A poesia vem em primeiro lugar na sequência, pois se trata do meio de expressão no qual se inspira o compositor. Sua música já é uma releitura da poesia. Talvez o compositor procurasse expressar aquilo que se encontra oculto na poesia, ampliando as reverberações poéticas da escrita. Muitas 
vezes, essa releitura eleva uma poesia, engrandecendo-a em suas dimensões. Por isso, a análise desse processo criativo em música é essencial na concepção da obra para o executante ou performer, que, por sua vez, faz também a sua própria releitura - levando em consideração a sua vivência, sua essência ontológica - para a elaboração interpretativa da canção.

Assim, "uma das mais óbvias fontes da compreensão do comportamento humano em conexão com a música é o texto da canção. Os textos denotam aspectos linguísticos, muito mais que sons musicais. No entanto, eles fazem parte integral da música e há uma nítida evidência de que a palavra, em conexão com a música, difere do discurso comum" (MERRIAM, 1964, p. 187).

Lembramos que se lidamos aqui com um gênero musical como a canção, nossa concepção é a de que suas origens remontam ao Zeitgeist dos primórdios do romantismo. Assim, como temos o advento do Lied na Alemanha, temos também ao mesmo tempo o estabelecimento do lundu e a modinha no Brasil. São projetos de uma mesma época em que ocorre a emancipação da melodia, da voz humana que canta os sentimentos livres e individuais, idealizados desde, pelo menos, a teoria de um Jean Jacques Rousseau em seus artigos musicais na Encyclopédie de Diderot. Mais importante que a música instrumental (sonata) passa a ser justamente a música cantada. Herdeira direta do espírito iluminista no processo de substituição da ária operística, a canção (Lied, modinha ${ }^{1}$ etc.) passa a representar, enquanto gênero vocal protagonista da melodia emancipada, o que há de mais importante da alma humana expressa por música.

Eis a estrutura da tese:

Capítulo 1- Canção sem palavras: será abordada a questão do vocalize, a voz por si, a ausência de palavras na canção através da obra O meu amigo Koellreutter, de Gilberto Mendes (1922) composta para

\footnotetext{
${ }^{1}$ Pode-se até afirmar, por exemplo, que os Lieder de Schubert fossem, talvez, obras de arte de maior relevância, mas jamais poderemos diferenciar a essência do gênero Lied em relação às melodias acompanhadas no Brasil daquela época, porque tanto o Lied como a modinha fazem parte de um mesmo e único gênero que surge no final do século XVIII e se estabelece definitivamente no início do século XIX: um mesmo Zeitgeist tanto na Alemanha como no Brasil, uma unidade musical que faz com que o velho e o novo mundo sejam um só.
} 
voz feminina, marimba e piano, em 1984, em comemoração ao septuagésimo aniversário de Hans-Joachim Koellreutter (1915-2005). Koellreutter é conhecido por sua atuação como professor de vários compositores e educadores de música no Brasil desde o final da década de 30 do século passado; e no encontro com a estética oriental vislumbrou uma estética do porvir para o ocidente. Gilberto Mendes, por sua vez, tenta retratar magistralmente, de forma lúdica, esse encontro de Koellreutter com a estética oriental nessa obra musical.

Capítulo 2- Gueixa: é tema da canção Japonêsas de Heitor Villa-Lobos (1887-1959) para voz e piano. Apesar de a imigração japonesa ter ocorrido em massa a partir de 1908, é mais provável que o germe da criação de Villa-Lobos, em 1912, tenha sido o movimento Japonisme, que eclodiu no final do século XIX e influenciou, tanto a música como os movimentos impressionista, pós-impressionista, simbolista e art nouveau da Europa Ocidental. Esse movimento exerceu fortes influências em Debussy, que por sua vez, inspirou essa obra de Villa-Lobos, cuja tendência composicional orientalista é evidente, mesmo sem ter tido provavelmente qualquer cons(ciência) desse conceito.

Capítulo 3- O mar de Suzu: Suzu é uma cidade na Província de Ishikawa no Japão. Nas composições poéticas da cultura japonesa, a natureza tem uma conotação metafórica exprimindo todos os sentimentos humanos. Há ainda uma veneração, respeito e religiosidade aliada a uma inter-relação estreita do homem e a natureza. As artes tradicionais japonesas têm, portanto, fortes vínculos na natureza, inclusive a escrita baseada em ideogramas. E é nesse contexto que o movimento da poesia concreta emerge inspirada também a partir dos ideogramas da poesia japonesa. Suzu é uma cidade cujo hino de uma escola primária Ōtani Shōgakkō foi composto por Luis Carlos Lessa 
Vinholes. Esse pequeno hino, sem bordas e sem pentatonismos retrata o "vazio" do jardim zen, ultrapassando fronteiras continentais.

Capítulo 4 - Um punhado de areia: é título traduzido do poema (tanka) de Takubouku Ishikawa de uma das canções de Cinco Canções Japonesas de Rodolfo Coelho de Souza composta para soprano, harpa e marimba. Descrevemos um estudo relacionando as classes sociais com o pentatonismo. É dentro dessa perspectiva que analisamos a obra, objetivando comparar os conjuntos pentatônicos utilizados em Cinco Canções Japonesas com as cinco escalas pentatônicas da música vocal tradicional japonesa, baseadas em estudo de Ichiro Nakano, mesmo que essa premissa não tenha sido a intenção do autor. Coelho de Souza, todavia, com todo seu aspecto engenhoso da obra, ornamenta com sutileza o sentimento recôndito nela (NAKANO, 1983, p. 244-266).

Capítulo 5- Flores: é uma abordagem sobre a flor do ipê na canção Acalanto para Noemi de José Antônio de Almeida Prado. A flor é um elemento da natureza intensivamente cultuado pelos japoneses. A cerejeira em flor, um dos ícones da cultura japonesa, inspirou também uma bela canção: sakura, sakura de autor anônimo. Entre tantas artes tradicionais japonesas onde se cultua a flor - sem esquecermos o ikebana - Zeami, dramaturgo do Japão da idade média, utiliza o termo "flor" para desenvolver um tratado de interpretação sobre o ator do teatro Nō, mais precisamente sobre sua técnica e interpretação, cuja concepção é extremamente contemporânea. Através da fusão em que mesclam as notas pentatônicas, Almeida Prado deixa reverberando, como que "suspensas no ar", uma sonoridade etérea.

Não obstante as forças dramáticas entre o desejar e o querer, fica assim escolhido o caminho a ser percorrido com suas inevitáveis "perdas". 
CAPÍTULO 1: Canção sem palavras 


\subsection{A voz da canção}

O que dizer então sobre a canção sem palavras? Porque um compositor opta por um vocalize ou um bocca chiusa renegando o poema? Há exemplos de vocalizes que se tornaram notórios tais como o Vokaliz, Op. 34, $n^{\circ} 14$ de Serguei Rachmaninov (1873-1943) e a Bachianas Brasileiras $n^{\circ} 5$ de Heitor Villa-Lobos (1887-1959). O Vokaliz foi dedicado ao soprano coloratura Antonina Nezhdanova. Quando ela expressou desapontamento pela ausência de texto, Rachmaninov replicou lisonjeiro: "Que necessidade há nas palavras, quando você será capaz de comunicar tudo melhor e mais expressivo que qualquer pessoa através da sua voz e interpretação?”2 (KIMBALL, 2006, p. 465).

Segundo Eni Orlandi, "quando não falamos, não estamos apenas mudos, estamos em silêncio: há o 'pensamento', a introspecção, a contemplação, etc." (ORLANDI, 2007, p. 35) e acrescenta, "o silêncio de que falamos aqui não é ausência de sons ou de palavras [...]. O silêncio não é o vazio, ou o sem-sentido; ao contrário, ele é o indício de uma instância significativa. Isso nos leva à compreensão do vazio da linguagem como um horizonte e não como falta" (op. cit. p. 68).

Podemos constatar, então, que a ausência de texto na canção enriquece as múltiplas interpretações, que pode evocar, justamente porque não está delimitada por um idioma (língua) determinado. Chega-se, dessa forma, à universalidade dos sentidos primordiais da voz: a escuta da voz da mãe como o primeiro vínculo de comunicação com o mundo e o primeiro choro como o suspiro dramático da existência.

Todas as obras investigadas neste estudo são peças para voz e outro instrumento. A voz tem suas peculiaridades. Cada um tem a sua - tão autêntica como a impressão digital. A voz é, portanto, primeva, conduz-nos, quem sabe, a uma esfera profunda dos abismos da existência. Um "a" pode representar

\footnotetext{
2"What need is there of words, when you will be able to convey everything better and more expressively than anyone could by your voice and interpretation?"
} 
assim, o primeiro choro do bebê, o grito de alegria ou de dor, uma gargalhada ou um suspiro de prazer. E se pensarmos no canto - a voz enquanto instrumento da arte - aí sim já temos condições mais derradeiras da existência revelada - já que a arte potencializa a verdade (no sentido antigo da $\alpha \lambda \varepsilon \dot{\varepsilon} \theta \varepsilon \alpha)^{3}$ singular enquanto linguagem (manifestação existencial).

A Bachianas Brasileiras $n^{\circ} 5$ de Villa-Lobos é exemplo de sentimento profundo evocado por um vocalize em "a", de uma voz que ecoa no sentido aparente, mas desvenda o sentido oculto da obra. Uma voz que antecede a descrição de um entardecer de uma paisagem tropical lânguida, entoando um sentimento nostálgico e melancólico. Voz essa que provoca a sensação profunda e dolorosa do passar inevitável do tempo.

Ao ouvirmos uma voz, sabemos muitas vezes sobre o estado d'alma do interlocutor. Portanto, ao trabalharmos uma voz, principalmente se for profissional, devemos elaborar sua construção no seu todo, ou seja, seu aspecto fisiológico, psicológico, intelectual e espiritual. Jacqueline Bonnardot define que o bom cantor:

é um artista que domina seu corpo, seu espírito e sua sensibilidade para o trabalho regular da postura, do sopro, da flexibilidade e do relaxamento do aparelho vocal, da dicção e do enriquecimento de usar a imaginação. Ele sabe utilizar sua voz sem cansaço, em inúmeros estilos, para a felicidade do público e dele mesmo ${ }^{4}$ (BONNARDOT, 2004, p. 4).

O compositor, por sua vez, ao trabalhar com esse instrumento multifacetado para elaborar a sua obra, deve, dentre outros procedimentos,

\footnotetext{
3 alétheia (enunciado, esclarecimento, memória) se encontra em oposição a léthe (silêncio, obscuridade, esquecimento). Assim, a alétheia (esta verdade desvelada enquanto acontecimento da verdade) não se opõe à "mentira", tal como em sua tradução latina tardia. Nem muito menos há uma oposição entre o verdadeiro e o falso. Trata-se antes de uma oposição entre o revelado e o oculto. O prefixo "?" indica aqui uma negação, portanto, alétheia indica "lembrança", expressa por um "não-esquecimento". Mas a tradução de alétheia por veritas culminou com o conceito de verdade não só enquanto certeza cartesiana, mas também relacionado à incapacidade crítico-reflexiva de alguns setores das ciências modernas em meio à condição redutiva de um determinismo tecnológico.

${ }^{4}$ C'est un artiste qui maîtrise son corps, son esprit et sa sensibilité par le travail régulier de la posture, du souffle, de la souplesse et de la décontraction de l'appareil vocal, de la diction et de l'enrichissement de son imagination. II sait utilizer sa voix sans fatigue, dans de nombreux styles, pour le bonheur du public et pour le sien.
} 
estabelecer a voz que vai utilizar: se será uma voz feminina ou masculina, aguda ou grave, leve ou pesada, da mesma forma quando escolhe um instrumento em sua orquestração para inserí-lo na textura adequada. Aliás, escrever para voz faz parte da orquestração (recurso esse indissociável do processo criativo como um todo) de um compositor. Ou seja, não há como separar a poética de um compositor do modo com que ele escreve para os instrumentos e as vozes (em amplos processos notacionais e de relações de timbre, equilíbrio, densidade, textura, etc.).

A voz da canção, com palavras ou não, nas suas mais variadas

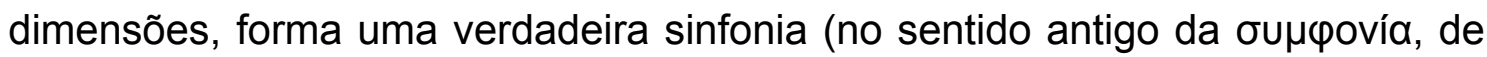
"sons afins") de vozes: do poeta, do compositor e do intérprete.

\subsection{O meu amigo Koellreutter}

O meu amigo Koellreutter é uma obra composta para voz feminina, marimba e piano, no ano de 1984, em comemoração ao septuagésimo aniversário de Hans-Joachim Koellreutter. Podemos defini-la como uma canção sem palavras, pois uma canção, na maioria das vezes, é um acasalamento entre música e texto. Entretanto, segundo Heloísa Valente, "uma voz pode revelar mais verdades que o conteúdo do texto" (VALENTE, 2004, p. 4). Já Koellreutter é conhecido por sua atuação como agitador cultural e professor de vários compositores e educadores de música no Brasil desde o final da década de 30 do século passado. Aqui traremos à tona a influência de certa musicalidade japonesa nessa obra de Gilberto Mendes. Nela podemos encontrar as nuances sutis do pentatonismo numa estrutura minimalista.

Gilberto Mendes, nascido em 1922, ano da famosa Semana de Arte Moderna, representa um marco na história da música brasileira como um dos maiores nomes da segunda metade do século XX. A Semana de Arte Moderna no Brasil passou para a história como o episódio que inaugurou simbolicamente o modernismo - não obstante Villa-Lobos já ter sido moderno bem antes disso. E as obras de Gilberto Mendes, tal como as de Villa-Lobos, 
são expressões instigantes da música brasileira sem deixar-se levar por estereótipos externos ou manipulados de brasilidade. Revelam antes uma pluralidade de influências nessa teia de interligações sem fronteiras das criações artísticas, não obstante sua inequívoca singularidade.

Ainda sobre a Semana de 22, ao lado de Oswald de Andrade, Mário de Andrade lidera o movimento que "inaugura a consciência da necessidade da renovação estética no Brasil e desenvolve o debate sobre o vínculo intrínseco da arte com as questões sociais, através da concepção da brasilidade" (MACHADO NETO, 2003, p. 2). Lembramos que os manifestos redigidos por Oswald de Andrade, Pau-Brasil (1924) e Antropofágico (1928), foram ainda mais característicos na busca pela identidade nacional que a própria Semana de 22 (essa se restringindo antes aos modismos das vanguardas parisienses). No Brasil, logo após os manifestos de Oswald, eclodia a manifestação artística, cujo preâmbulo teve início nos anos anteriores buscando uma suposta distinção da posição "brasileira" em relação à "européia". O impasse sobre onde resgatar os elementos nativos e os conceitos de brasilidade e da nãobrasilidade tornou-se uma questão fundamental daquele Zeitgeist. Assim, intelectuais e artistas reuniram-se na busca da identidade musical brasileira. Procuram responder pontualmente à complexa questão: quem somos nós, afinal? De antemão, chegou-se ao seguinte denominador comum: o povo brasileiro não é constituído exclusivamente por uma só etnia, já que antes somos caracterizados pela miscigenação. Mas hoje, já com o devido distanciamento crítico, cabe, talvez, a questão: seria possível pensar o Brasil, ainda agora, como um fenômeno cultural extra-europeu ou extra-ocidental? Até que ponto um artista europeu poderia ser considerado enquanto personalidade mais legítima como descendente da tragédia grega do que um americano, africano ou asiático? Ou então, o que poderia ser considerado genuinamente nosso? Mário de Andrade se debruçou com afinco sobre essa questão - levado pela onda do polêmico Oswald - em seu Ensaio sobre a música brasileira (1928), elucidando parte de sua essência (não obstante outras concepções 
mais sectárias e menos iluminadas nessa mesma obra e que até contradizem o que vamos citar aqui):

\begin{abstract}
Se fosse nacional só o que é ameríndio, também os italianos não podiam empregar o órgão que é egípcio, o violino que é árabe, o cantochão que é grecoebraico, a polifonia que é nórdica, anglosaxonia flamenga e o diabo. Os franceses não podiam usar a ópera que é italiana e muito menos a forma-de-sonata que é alemã. $E$ como todos os povos da Europa são produtos de migrações préhistóricas se conclui que não existe arte européia... por tudo isso, música brasileira deve de significar toda música nacional como criação quer tenha quer não tenha caráter étnico (ANDRADE, 1928, p. 16).
\end{abstract}

As fronteiras entre o autóctone e o alienígena tornam-se "borrados" nesse contexto moderno, como afirma Renato Ortiz (ORTIZ, 2000, p. 13). Aliada à preocupação com a identificação da música nacional estava a renovação do estilo nas artes, pois havia entre os jovens paulistanos da Semana de 22, especialmente influenciados pelos manifestos de Oswald, uma consciência de que a arte brasileira deveria ser transformada radicalmente. A então denominada "arte futurista" correspondia às exigências de novas linguagens, adequadas ao ambiente do século: à velocidade, à simultaneidade, à máquina. Assim como a sociedade se renovava com a nova realidade, a arte abria para si um novo horizonte técnico-estilístico. Essa atmosfera de transformação desencadeou certo tipo de recusa ao passado, uma vez que as novas forças, além de irreversíveis, se propagaram, criando, assim, novas linguagens poéticas, novas relações com o mundo, uma crítica da sociedade e, especialmente, do papel desempenhado pela arte como ornamento de uma burguesia refratária às transformações.

A Semana de Arte Moderna e os manifestos de Oswald, além de terem sido um dos pontos de partida para a discussão em torno da identidade musical brasileira, foi também terreno fértil para o desdobramento e a formulação de respostas. Formou-se, assim, um cenário para a percepção entre uma arte já estabelecida e as novas propostas de transformação, dando espaço para uma arte pretensamente de caráter nacional em seu tempo. 
O autodidata Gilberto Mendes é fruto desse terreno polêmico. Esteve, eventualmente, sob orientação de Cláudio Santoro e Oliver Toni, mesmo que em ambos os casos as aulas não tenham sido numerosas nem sistemáticas. Após uma produção de juventude que se encontrava em sintonia com o melhor dos neofolclorismos ${ }^{5}$ de Villa-Lobos e Cláudio Santoro, participou também, logo em seguida, dos Cursos de Férias de Darmstadt, no início dos anos 60 do século XX, tendo assistido concertos e aulas de Boulez, Stockhausen e Pousseur. O próprio Gilberto Mendes confessa como aquelas viagens à Alemanha foram importantes nos rumos posteriores de sua poética:

\begin{abstract}
Nós viemos de Darmstadt assim devidamente dispostos a não fazer aquela música que a gente ouviu lá. Não que estivéssemos contra aquilo, de jeito nenhum, aquela música até nos impressionou muito, foi até um grande choque, choque no bom sentido da palavra, porque abriu as nossas mentes mais ainda, porque elas já estavam abertas neste sentido, para o novo. A lição deles era fazer o novo, mas a gente queria fazer uma música que não tivesse nenhuma coisa a ver com a música européia (depoimento no DVD A Odisséia Musical de Gilberto Mendes).
\end{abstract}

Paralelamente a esse processo da busca por uma poética pessoal construída a partir de influências cosmopolitas, Gilberto Mendes se encontra com outro agitador cultural ávido também na busca de questões instigantes em relação à modernidade: Hans-Joachim Koellreutter. Koellreutter nasceu em Freiburg, na Alemanha, em 1915, e atuou inicialmente como flautista. Radicouse no Brasil em 1937, período de Getúlio Vargas, em virtude do regime nazista que assolava seu país. Na década de 1940, ao lado de Eunice Catunda, Cláudio Santoro, Guerra-Peixe e Edino Krieger, tomou parte do movimento Música Viva. Koellreutter entrou em contato pela primeira vez com a música do Oriente na década de 50, principalmente com a música clássica da Índia e com o gagaku do Japão, o que permitiu reforçar alguns ideais já implícitos como a "estética do impreciso (tendências substituem ocorrências definidas) e do paradoxal (fundem-se conceitos estéticos aparentemente contraditórios)" (KOELLREUTTER, 1983, p. 11).

\footnotetext{
${ }^{5}$ O conceito de "neofolclorismo" remonta a Igor Stravinsky (Poética musical em seis lições).
} 
Koellreutter encontra no Japão um modelo que poderia ser chamado de um amalgamento de contradições entre o tradicional e o novo, o ocidente e o oriente, e que se entrelaçam de uma forma harmoniosa. E essa poética não se deixa levar pelos rumos pré-estabelecidos.

\begin{abstract}
Tais ideais são, por exemplo: concentração extrema da expressão, economia de meios, renúncia ao prazer exclusivamente sensorial, clareza e precisão, liberação de um conceito de tempo racionalmente estabelecido, assimetria, forma aberta e variável e outros conceitos mais (op. cit. p. 17).
\end{abstract}

São afirmações que revelam nas correspondências com o Prof. Satoshi Tanaka - professor de alemão na Universidade Meisei, Tóquio - que resultaram em uma publicação que nomeou de Estética: à procura de um mundo sem "visà-vis". Trata-se de uma coletânea de doze cartas entre ambos, entre 1974 e 1976, nas quais fazem reflexões em torno das artes do oriente e do ocidente. Ambos também analisam os parâmetros que estabelecem os processos culturais do conservadorismo e da renovação.

O meu amigo Koellreutter contempla a forma A-B-B1-B2-Coda. Não há armadura de clave e muito menos qualquer tonalidade definida na obra, uma vez que se trata de uma rara fusão de certo gosto melódico japonês idealizado (e o uníssono predominante entre marimba e canto é antes um tempero timbrístico de linguagem) com um acompanhado ao piano efetuado por acordes com fundamentos tonais, mas não funcionais (mesmo que às relações tonais estejam sempre acrescentadas notas estranhas ao contexto tonal da nota fundamental de cada acorde). Na parte B, a mão esquerda do piano, prossegue em quintas paralelas ou acordes sem as terças de Dó maior, Ré maior, Lá maior (as terças estão nos acordes na parte da mão direita do piano ou na melodia entoada pela voz) nos compassos 9 a 12; 21 a 24; 25 a 28; 29 a 32; 33 a 36; 37 a 40. Ou seja, como módulos que se repetem.

O conjunto pentatônico que aparece nessa obra é formado pelas notas Dó, Mi, Fá \#, Lá, Si e uma pequena variação de Mi, Fá, Lá, Si e Dó, que em se tratando de conjuntos pentatônicos, poderíamos classificá-lo também como o 
segundo conjunto, pois há uma transposição do primeiro conjunto para o segundo e uma alteração da nota Fá \# para Fá, como se pode verificar na Figura 1.
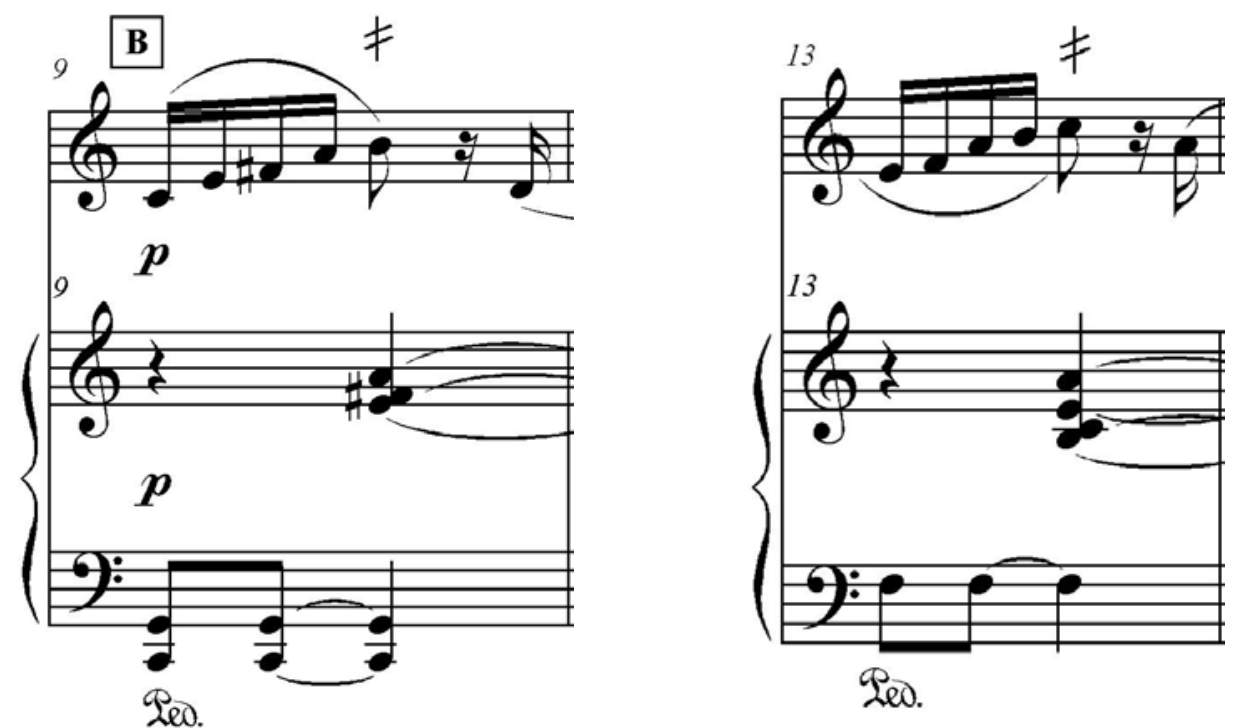

Figura 1: Compassos 9 e 13 de O meu amigo Koellreutter (Gilberto Mendes).

Gilberto Mendes oferece sugestões na partitura para sua execução da seguinte forma:

Para piano, voz feminina e marimba (em uníssono) com baquetas de feltro trançado - sempre piano, igualmente sonoro, tudo na mesma intensidade, tranqüilo, sem acentuar tempos fortes - voz senza vibrato, como um instrumento, bem legato, canta sobre a vogal "a", com a boca preparada para "o" - marimba realiza: $\neq$ tremolo sobre a nota indicada e 屜 (símbolo abreviado $F$ ) este ritmo - ordem de execução: ABB1B2 Coda, somente na parte B repetir 4 vezes os 4 compassos iniciais, isto é, dobrar ritornello.

Gilberto Mendes apresenta Koellreutter inserido numa atmosfera sonora oriental nos 44 compassos da obra. Gilberto Mendes expressa ainda uma sonoridade "oriental" identificada pela estrutura minimalista e pentatônica da obra. A década de 80 é marcada pela introdução do minimalismo no Brasil. 
Segundo o compositor Rodolfo Coelho de Souza, a primeira fonte de impacto do minimalismo foi a obra de Gilberto Mendes e não, como às vezes se imagina, a música dos americanos. O minimalismo faz lembrar aspectos orientais de sonoridade pela sua característica repetitiva, remetendo à atmosfera meditativa das religiões e filosofias orientais.

A voz senza vibrato, em uníssono com a marimba, entoa vocalizada a frase melódica que se inicia sempre com um conjunto pentatônico ascendente, seguido de uma pausa, o que gera um estado de suspensão e sugere questionamento. Essa frase melódica se constitui de quatro compassos que se repetem regularmente com pequenas variações até a coda (Figura 2). 0 aspecto timbrístico etéreo gerado pela junção da voz e marimba se harmoniza com o acompanhamento acordal minimalista do piano.

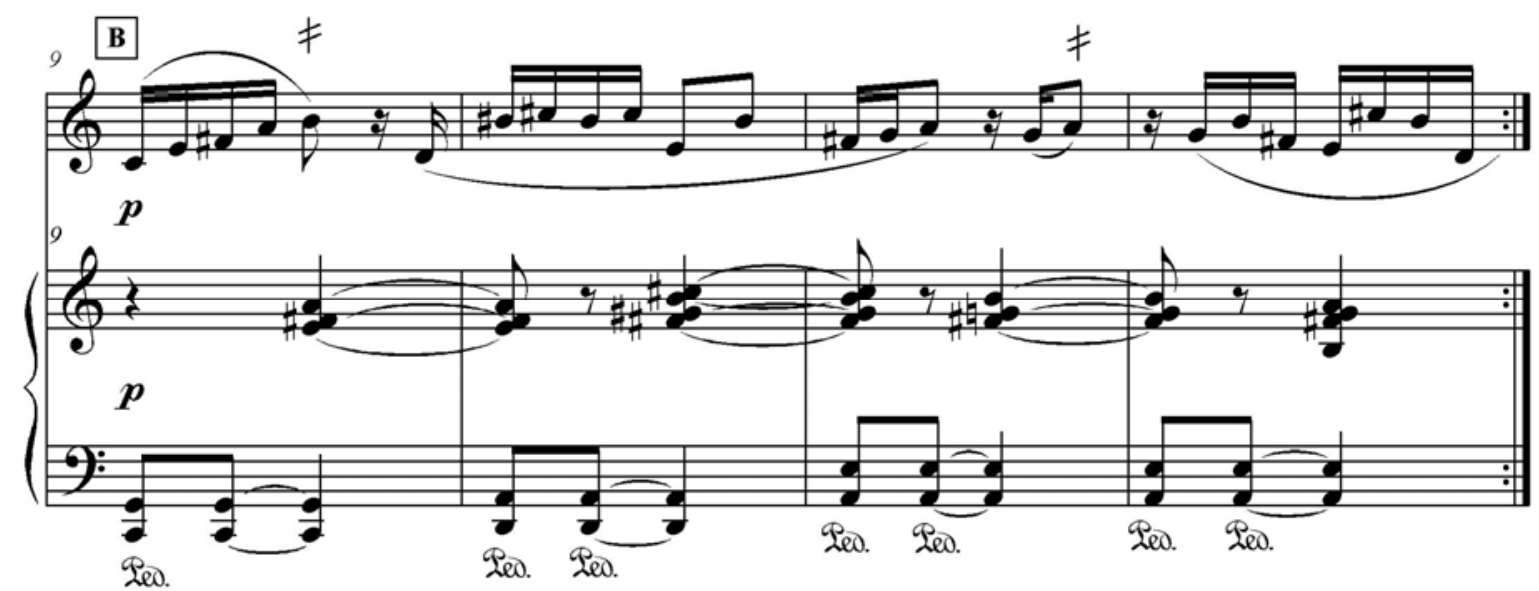

Figura 2: Compasso 9 a 12 de O meu amigo Koellreutter (Gilberto Mendes).

Em compasso 2/4 e semínima igual a 52, os acordes da mão direita do piano são de semínimas com ligaduras, e os da mão esquerda, colcheia e colcheia com ligaduras. Sobre esses acordes, a voz se desliza em semicolcheias. Em síncopa, quase todos os acordes da mão direita provocam o deslocamento da acentuação rítmica, gerando certa instabilidade, uma 
sensação flutuante que caracteriza com sutileza a atmosfera japonesa, um estado de vir-a-ser sucessivo.

A voz é entoada ao longo da obra em "a", com boca preparada para o "o", conforme orientações do próprio compositor. Gilberto Mendes sugere, assim, uma sonoridade velada e oculta. Mesclando-se com a marimba, transcende a identificação da cor sonora isolada de cada meio de emissão.

Uma canção sem palavras como essa de Gilberto Mendes amplia nossas dimensões interpretativas justamente por não ter uma esfera delimitada pelo poema. São sugestivas como tantas outras obras suas. Há aquelas sem partituras determinadas, compostas como se fossem "receitas de música" (ou bulas). Exemplo disso temos em Blirium, Objeto Musical, Pausa e menopausa ou ainda a Ópera Aberta, essa em especial, cuja execução é indicada exclusivamente por instruções.

Em uma das correspondências de Koellreutter para o Prof. Tanaka, ele afirma ter rejeitado sempre a idéia do som pelo som. Para ele, o som e o silêncio formam polos complementares. O silêncio como elemento fundamental da música, sem a qual a vivência musical não é possível. Mas, não é o silêncio no sentido da não existência do som, e sim no sentido de seijaku, ou seja, calma interior e equilíbrio, como fundo originário da vivência espiritual.

O silêncio, nessa obra de Gilberto Mendes, aparece como pequenas pausas de semicolcheias entrecortadas por entre os grupos de notas de semicolcheias na parte vocal, determinando respirações curtas e rápidas. Esse movimento rítmico sugere um estado de ansiedade ou de busca "À procura de um mundo sem 'vis-a-vis'” (nome dado à publicação das correspondências entre Koellreutter e Tanaka). No entanto, a estrutura minimalista concedida ao piano, apesar de sincopada, vai acalmando, finalizando sem a parte vocal nos últimos seis compassos, levando finalmente à atmosfera de quietude, de calma interior.

Pode-se afirmar que Gilberto Mendes escreve o que ouve dentro dele, sem estar engajado por este ou aquele movimento poético, quer seja pensando na música brasileira ou japonesa, como afirmou Caio Pagano em uma de suas 
considerações em relação ao compositor santista. O próprio Gilberto Mendes declara: "Fazer arte, para mim, é pôr em ordem o material que eu tenho à minha mão" (in DVD A Odisséia Musical ...). E exemplifica, ao discorrer sobre a sua obra "Blirium", fundamental na sua produção musical, pois foi composta quando estava preocupado com a estrutura, construção, rigidez e série; com ela conseguiu superá-las, mas mantendo todos os fundamentos. "Blirium" é nome de um remédio da época, objetivando dar um nome pop quebrando, assim, um pouco da rigidez das estruturas. Dentro da obra, Gilberto permite citações e elementos, tanto da neue musik à Darmstadt como também da música de John Cage. Mas suas citações eram músicas de qualquer tipo. Da Antiguidade grega à Idade Média, da Ars Antiqua e Ars Nova ao Romantismo, de manifestações populares (um tango ou um saudosismo do lídio nordestino tipicamente sincopado), de linguagens ocidentais ou orientais ou ainda, não raramente, que remontam às mais complexas estruturas eruditas ou "maquinações de vanguarda". Todas essas fontes são temperos de linguagem para Gilberto Mendes. Nessa conjuntura, ele sentiu, então, a possibilidade de conviver conjuntamente num mesmo tempo em sua obra com os mais variados sistemas musicais de diferentes épocas históricas e lugares geográficos, e, assim, viabilizar em sua monumental obra os vários estilos poéticos da música de todos os tempos num conglomerado que não deixa de sustentar paradoxalmente uma singular unidade.

Essa é a sua maneira de introduzir de maneira descompromissada elementos alienígenas, aparentemente paradoxais em um processo de desfacelamento das bordas e muros, permitindo livres acessos a qualquer contexto musical através dos tempos e por meio dos mais diversos costumes do cotidiano humano, por mais distantes que pareçam estar. E com maestria consegue inserir, às vezes, uma pitada de humor, o espírito lúdico e a identificação de uma linguagem solitária.

É dessa forma que podemos identificar O meu amigo Koellreutter, escrita pouco depois do lançamento do filme Furyō, que se passava num campo de prisioneiros no Japão durante a Segunda Guerra e que tinha como 
atores, entre outros, Takeshi Kitano, Tom Conti, Ryuichi Sakamoto e David Bowie. Esses dois últimos são músicos populares (aliás, de alguma sofisticação, diga-se de passagem), mas também atores que desempenharam muito bem seus papéis. A composição da música do filme era do próprio Sakamoto, de notável presença, utilizando sons sintetizados de maneira inteligente e fazia referências musicais às culturas orientais (numa composição evidentemente pentatônica). Está claro que a música-tema do filme - executada através do timbre de marimba - e seus contornos melódicos são diretamente revisitados na essência estrutural de O Meu amigo Koellreutter. De fato, bastante criativa, tanto a música original do filme como a releitura de Gilberto Mendes. E como essa peça de Gilberto Mendes foi diretamente influenciada por essa trilha sonora, tal processo se caracteriza enquanto pós-modernismo, pois a música de concerto dialoga, antes de mais nada, com o universo paralelo da música para cinema.

Rui Vieira Nery, musicólogo português, define:

\begin{abstract}
é um autor que junta o cosmopolitismo, o acompanhamento das tendências de vanguarda mais importantes de seu tempo com uma capacidade de inserção na comunidade, nas raízes locais, que nunca passa por folclorismo, mas que está presente numa identidade muito forte brasileira, sem precisar agitar a bandeira, que consegue digerir todas as escolas sem ficar preso a nenhuma e que consegue marcar uma individualidade artística muito forte ao longo de toda sua carreira. E essa independência de espírito, essa capacidade de ser cidadão do mundo, e cidadão do Brasil ao mesmo tempo e de ser um criador independente, que soube achar suas próprias diretivas, eu acho que é realmente, um exemplo (in DVD A Odisséia Musical...).
\end{abstract}

Condizente com algumas tendências referenciais da música do século XX, O meu amigo Koellreutter reflete o amálgama de concepções só aparentemente divergentes entre sistemas e linguagens, sobrepostas e multifacetadas, assim como a reverberação da miscigenação de várias representações humanas. Mas, decisivo para a compreensão dessa obra é o seu caráter derradeiro de liberdade poética contemporânea já num momento de plena superação da "velha antinomia vanguarda versus nacionalismo" (MENDES, 1991, p. 40), uma vez que O meu Amigo Koellreutter já está além 
de qualquer proposta neofolclorista, quer seja influenciada pelo Ensaio (1928) de Mário de Andrade ou mesmo pela repercussão no Brasil do Discurso (1948) de Andrei Alexandrovitch $\mathrm{Jdanov}^{6}$, assim como ignora qualquer hermetismo à Darmstadt (tendo-se em vista a moda geral dos anos 60 e 70 de seguir as linhas ditas de vanguarda de Stockhausen, Boulez \& Cia). Nesse sentido, podemos falar de seu caráter pós-vanguarda ou, como querem alguns, pósmoderno (MENDES, 1991, p. 37-42).

\footnotetext{
${ }^{6} \mathrm{Jdanov}$ foi uma espécie de ministro da cultura da URSS nos tempos de Stalin. Seu Discurso pelo realismo na música (em suas próprias palavras, a tradição popular, a melodia, a tonalidade, o foclore) e contra o formalismo (entendido enquanto cosmopolitismo burguês ou decadência capitalista), ou seja, contra toda e qualquer espécie de experimentalismo moderno na música (atonalidade, técnica dos doze tons ou mesmo outros sistemas não tonais), influenciou diretamente vários compositores brasileiros, desde Camargo Guarnieri (que em 1950 publica sua Carta Aberta aos músicos e críticos brasileiros no jornal O Estado de São Paulo, de fato um plágio de Jdanov) até Guerra-Peixe e Cláudio Santoro, sendo que este último foi professor de Gilberto Mendes. Para Camargo Guarnieri, as linhas jdanovistas serviam perfeitamente à sua poética musical de sempre. No caso de Guerra-Peixe e Cláudio Santoro, que antes estavam atrelados ao Grupo Música Viva, a nova postura jdanovista que eles assumiram foi devida à militância deles no Partido Comunista do Brasil (PCB, fundado em 1922).
} 


\section{CAPÍTULO 2: Gueixas}


Em 1912, Heitor Villa-Lobos (1887-1959) compôs a canção Japonêsas, para voz e piano, cujo poema descreve uma gueixa, após a chegada do primeiro navio de imigrantes japoneses, o Kasatomaru, em Santos, no dia 18 de junho de 1908. Essa canção, composta logo após a chegada dos primeiros japoneses, a maioria deles de procedência rural, não parece evidenciar a inspiração do compositor para esse tema, pois a figura mítica da gueixa está vinculada ao ambiente urbano. Portanto, é muito provável que o germe da criação de Villa-Lobos tenha sido o movimento Japonisme, que eclodiu no final do século XIX e influenciou tanto a música da Europa Ocidental assim como os movimentos impressionista, pós-impressionista, simbolista e art nouveau (Jugendstil). Esse movimento exerceu forte influência em Claude Debussy (1862-1918), que por sua vez, parece refletir em Villa-Lobos, influenciando de maneira clara na composição dessa obra que apresenta fortes traços de orientalismo.

Segundo Ricardo Tacuchian em sua Paidéia Musical: Introdução à vida e obra de Heitor Villa-Lobos, propõe a divisão de sua produção em quatro fases: "a primeira é a de formação; a segunda é a década de 20 - a vanguarda modernista dos choros; a terceira está compreendida entre 1930 e 1945, exatamente quando ele inicia a primeira e termina a nona bachiana; e a quarta fase, que vai de 1945 até a sua morte, é a fase do Universalismo. E é justamente à primeira fase que corresponde essa canção, quando Villa-Lobos está à "procura de um estilo, a partir do conhecimento do Brasil, da vivência com a música urbana (chorões) e as influências européias (impressionismo)" (TACUCHIAN, 2008, p. 2).

No final do século XIX, Paris, no auge da belle époque exportava suas mais variadas correntes e movimentos artísticos. Assim define Johannes Willms: 
uma coincidência, mas o resultado de vários desenvolvimentos que se aglomeraram, reforçaram e se enriqueceram um ao outro. Belle Époque Paris foi um gigante catalítico pelas estridentes excitações, de medos sombrios e expectativas otimistas que eram tão característicos do fin de siècle e foram expressos por uma multidão de visões e escolas artísticas (WILLMS, 2002, p. 335) ${ }^{7}$.

\subsection{O movimento Japonisme}

Japonisme é um termo criado pelo crítico de arte francês Philippe Burty, em 1872, e surgiu em decorrência de duas exposições: a primeira, em 1862, em Londres com a exibição da coleção de Sir Rutherford Alcock's de gravuras e livros japoneses; e a segunda, em 1867, a Paris Exposition Universelle que introduziu as artes japonesas incluindo 100 ukiyo-e (gravuras japonesas) de Hiroshige e outros. Foi o ukiyo-e que, particularmente, impressionou os intelectuais e artistas. O ukiyo-e retrata o cotidiano das pessoas e a forma de entretenimento da população urbana do século XVII ao XIX, justamente no período em que o Japão, na era Tokugawa, permaneceu isolado. Assim que o Japão abriu seus portos em 1854, o universo das gueixas, entre tantos outros símbolos representativos dessa cultura, tais como os samurais, a cerimônia do chá, os jardins zen e toda a arte tradicional japonesa causaram fascínio aos intelectuais e artistas ocidentais.

São testemunhadas nessa arte gráfica popular ukiyo-e "imagens de um mundo flutuante", ou seja, uma arte retratando um mundo refinado, efêmero, de evocações hedonistas que inspiraram grandes artistas do Ocidente, contribuindo no enriquecimento dos movimentos como o Impressionismo, Pósimpressionismo, Simbolismo, Art Nouveau e o movimento da arte britânica (MASON, 2005, p. 344).

\footnotetext{
${ }^{7}$ In the Belle Époque, as the years between 1880 and 1914 came to be known, Paris developed into the world capital of fashion, art, and literature, and of life's pleasures. This was no coincidence but rather the result of various developments that coalesced, strengthened, and enriched one another. Belle Époque Paris was a gigantic catalyst for the shrill excitements, the somber fears, and the optimistic expectations that were so characteristic of the fin de siècle, and were expressed by a multitude of views and competing artistic schools and cliques.
} 
Vários artistas se inspiraram nestas gravuras japonesas para produzirem suas obras. Vejamos ${ }^{8}$ :

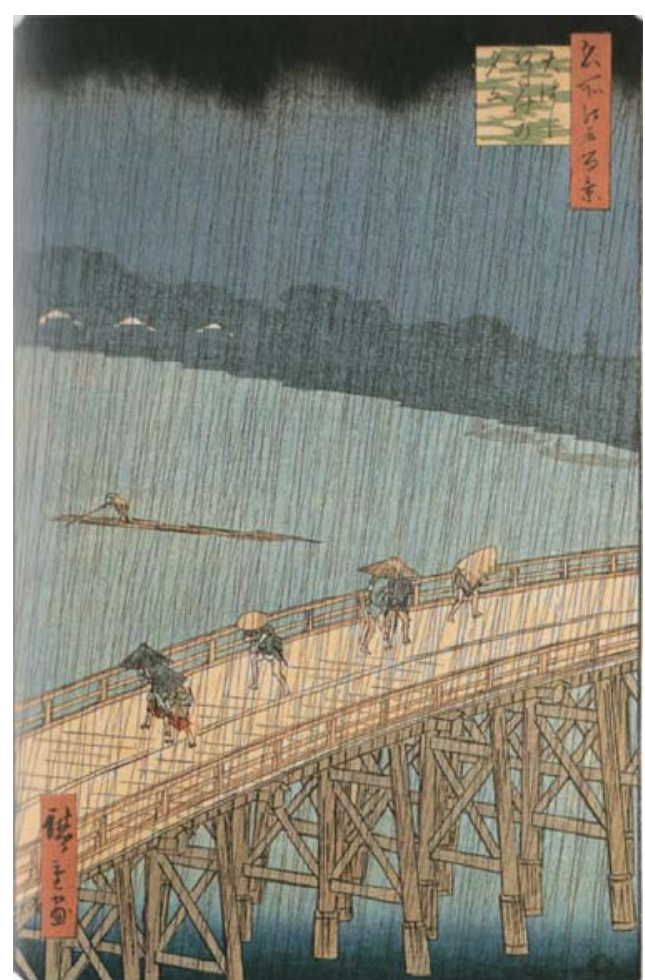

Figura 3: Pluie soudane sur le pont d'Ataka (Utagawa Hiroshigue), 1857 [p. 45].

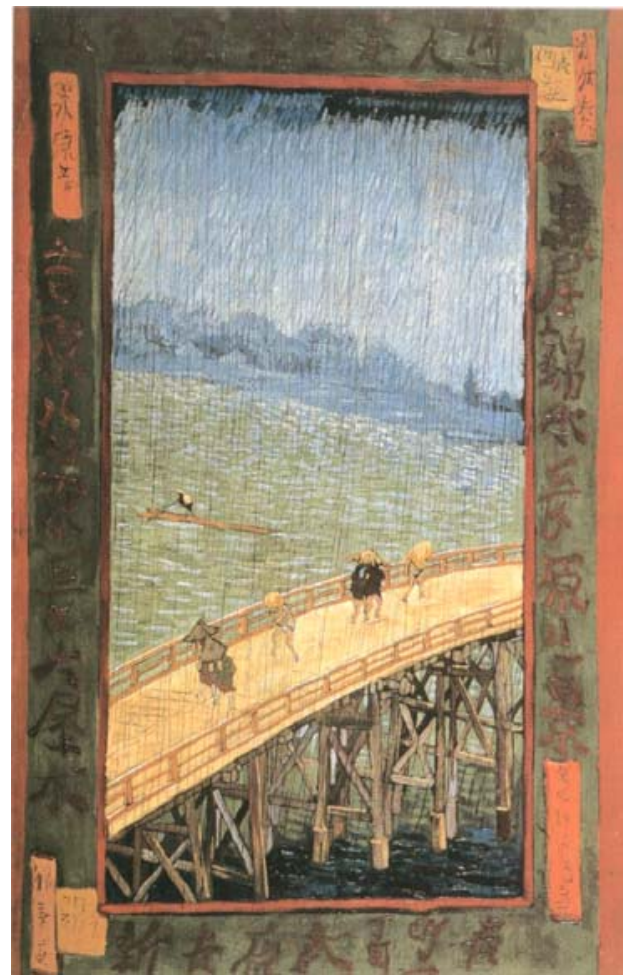

Figura 4: Pont sur la pluie (Vincent Van Gogh), 1887 [p. 45].

Vincent van Gogh (1853-1890) fez uma cópia dessa gravura japonesa de Utagawa Hiroshigue, da série Cem paisagens de Edo. Seu primeiro contato com as gravuras japonesas ocorreu ainda na Holanda ao ler a obra Chérie (1848) de Edmond de Goncourt's, cujo herói é o primeiro a dizer japonaiserie forever. Van Gogh estudava e colecionava gravuras japonesas. Em Paris, organizou exposição dessas gravuras em 1887, no Café Le Tambourin. Ele admirava as cores vibrantes e a forma de utilização das linhas e isso influenciou intensamente suas obras (LAMBOURNE, 2007, p. 44).

\footnotetext{
${ }^{8}$ Todas as figuras deste capítulo foram escaneadas do livro Japonisme: Échanges culturels entre le Japon et l'Occident de Lionel Lambourne (2007).
} 


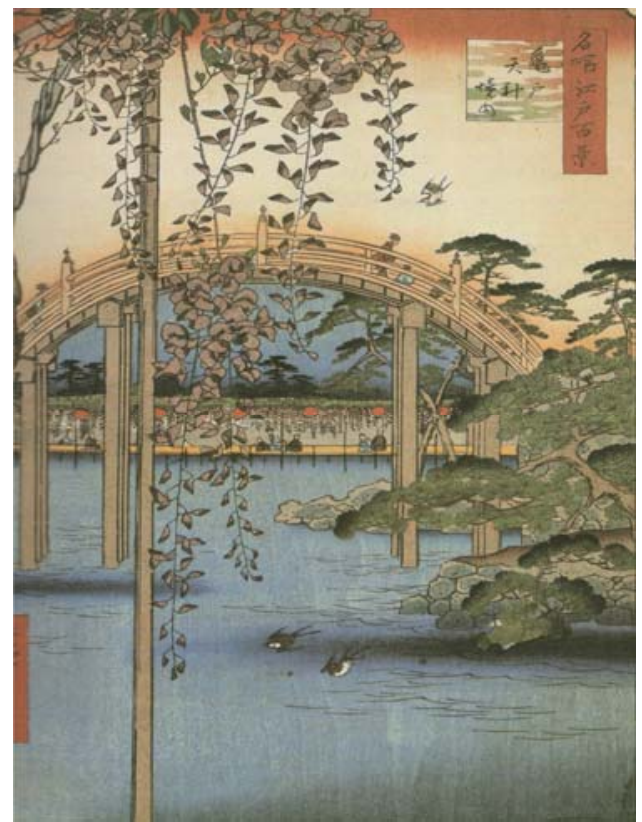

Figura 5:, Dans le jardins du sanctuaire Tenjin, Kameido (Utagawa Hiroshigue), 1857 [p. 194].

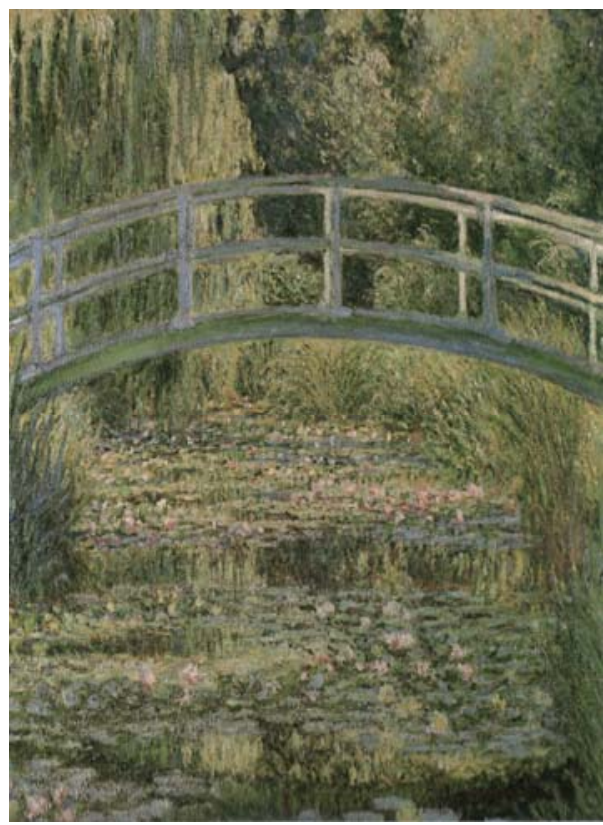

Figura 6: Le Bassin aux nymphéas (Claude Monet), 1899.

Os impressionistas também dividiram com os japoneses a profunda preocupação com a água, mais notavelmente Claude Monet (1840-1926). Ele também colecionava gravuras de paisagens de Hokusai. Tanto Hokusai como Hiroshige foram atrelados em temas similares, entre eles, a descrição visual dos efeitos da água nas cachoeiras, rios, lagos, tempestades e paisagens marítimas. Em 1883, Monet se estabeleceu em Giverny, onde se divertia criando o jardim. Entre as flores e plantas variadas que apreciava, ele gostava de cultivar as cerejeiras, outras flores e plantas japonesas (LAMBOURNE, 2007, p. 194).

Lautrec era um apaixonado pelas gravuras japonesas que chegou até mesmo a sugerir trocas pelas suas obras para obtê-las. Seus temas favoritos eram o entretenimento popular, dançarinos, salão de dança, bares e restaurantes, prostitutas e suas atividades que têm muitas afinidades com as gravuras japonesas, como, por exemplo, o Le poème de l'oreiller de Utamaro que Lautrec tinha inclusive uma cópia (LAMBOURNE, 2007, p. 61). 
Toda essa manifestação de interesses e curiosidades estava atrelada à aura que envolvia a Belle Époque como descreve Johannes Willms em seu livro Paris: from the Revolution to the Belle Époque.

Toda lenda tem uma base de fato. E a lenda da Belle Époque Paris como a capital do prazer e da imoralidade não era tão exagerada. Foi em Paris do final do século dezenove que o fenômeno social e moral da vida moderna fez a sua aparição, cedo e mais evidente que qualquer outra metrópole (WILLMS, 2002, p. 338) ${ }^{9}$.

O movimento Japonisme causou impactos e desdobramentos, não somente nas artes plásticas, mas também na música. Claude Debussy (18621918), que passara a infância em Cannes na casa de seu padrinho, Achille Arosa, teve ali dois encontros determinantes: com a música e com o mar (MASSIM, J.; MASSIM, B., 1997, p. 907). Sua relação com a água deve ter sido também um dos motivos pelos quais encontrou um apreço pelas gravuras japonesas de Hokusai e Hiroshige, que tanto se empenharam em descrever a água, como mencionado anteriormente. O aspecto imagético da música de Debussy se descortina ao longo de suas obras. Portanto, a famosa Grande Onda de Hokusai que se tornou notória no ambiente pariense é estampada na primeira edição da obra La Mer de Debussy, sendo extraído da gravura um pequeno fragmento estilizado (Figuras 7 e 8). A Grande Onda está ilustrada na capa das partituras, tanto na sua obra pianística como na sua posterior versão orquestral. Debussy confessa ao escrever para o seu editor sobre o mar: "satisfaz e mostra todos os humores"10 (LAMBOURNE, 2007, p. 151).

\footnotetext{
${ }^{9}$ Every legend has a basis in fact. And the legend of Belle Epoque Paris as a world capital of pleasure and immorality was not too exaggerated. It was in the Paris of the late nineteenth century that the social and moral phenomena of modern life made their appearance, earlier and more conspicuously than in any other metropolis.

${ }^{10}$ comblé et montré toutes ses humeurs.
} 


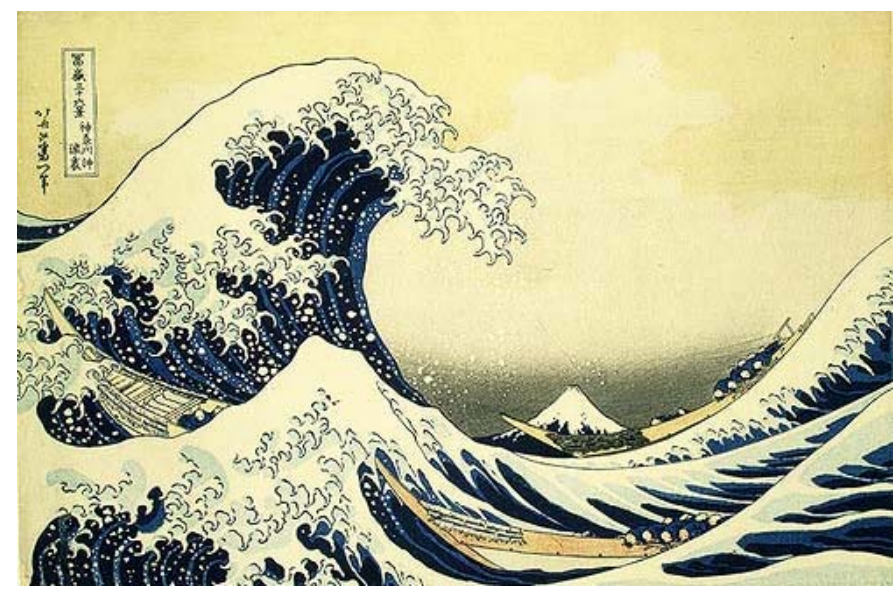

Figura 7: La Grande Vague (Hokusai), 1831[p. 59].

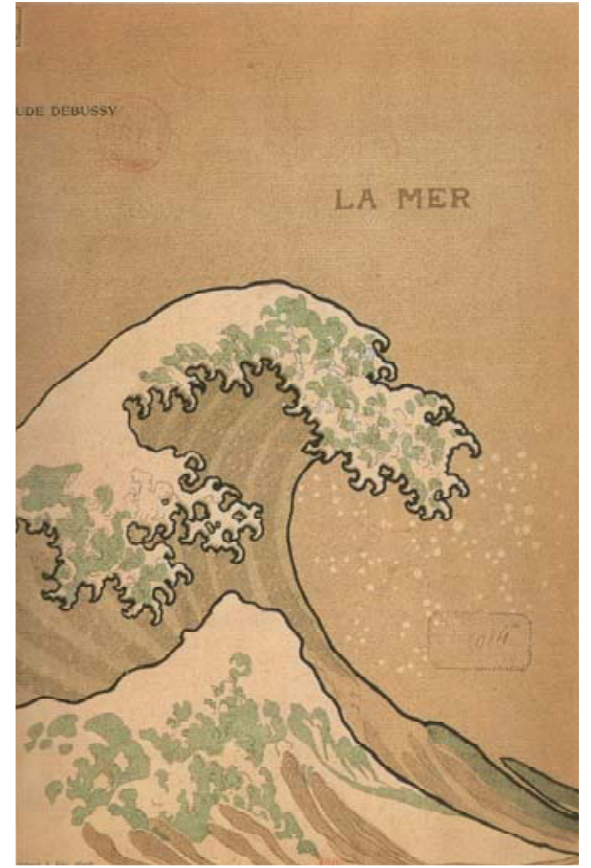

Figura 8: Jaquette de La Mer de Debussy Adaptation de La Grande Vague (Hokusai), 1905 [p. 151].

Além das gravuras japonesas, a imagem mítica da gueixa inspirava muitos artistas tais como Monet e Hans Makart. La Japonaise (Figura 9) é a esposa de Monet, vestida de quimono vermelho ornamentado de um ator do teatro Kabuki e leque na mão. The Japanese Woman (Figura 10) é uma camponesa austríaca seminua de quimono, de cabelos presos sob um guardasol de penas. Ela provoca um pássaro segurando um ninho cheio de ovos (LAMBOURNE, 2007, p. 111 e 125). 


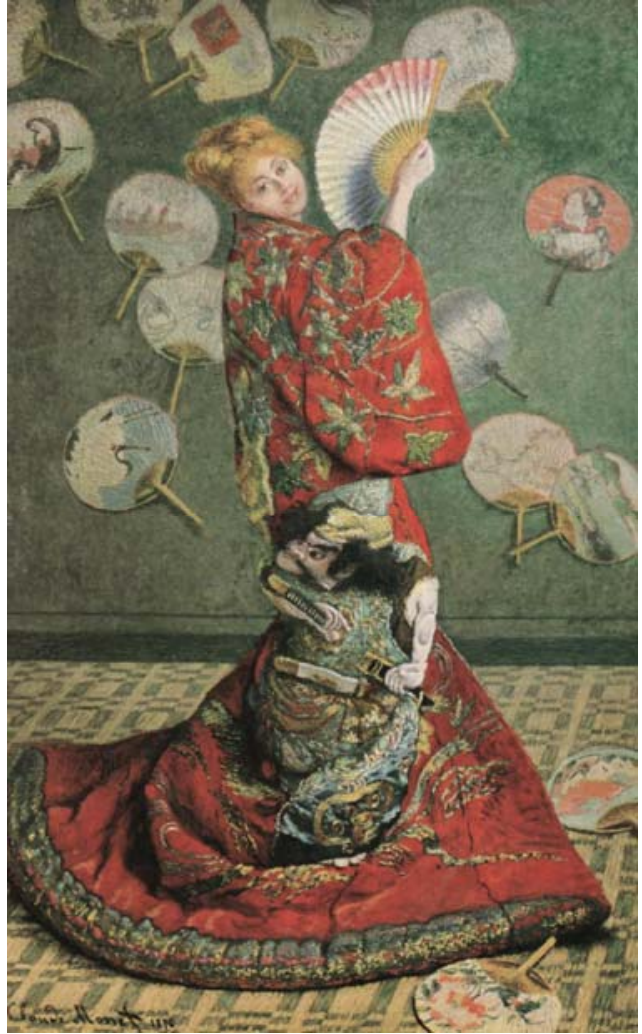

Figura 9: La Japonaise (Claude Monet), 1876 [p. 111].

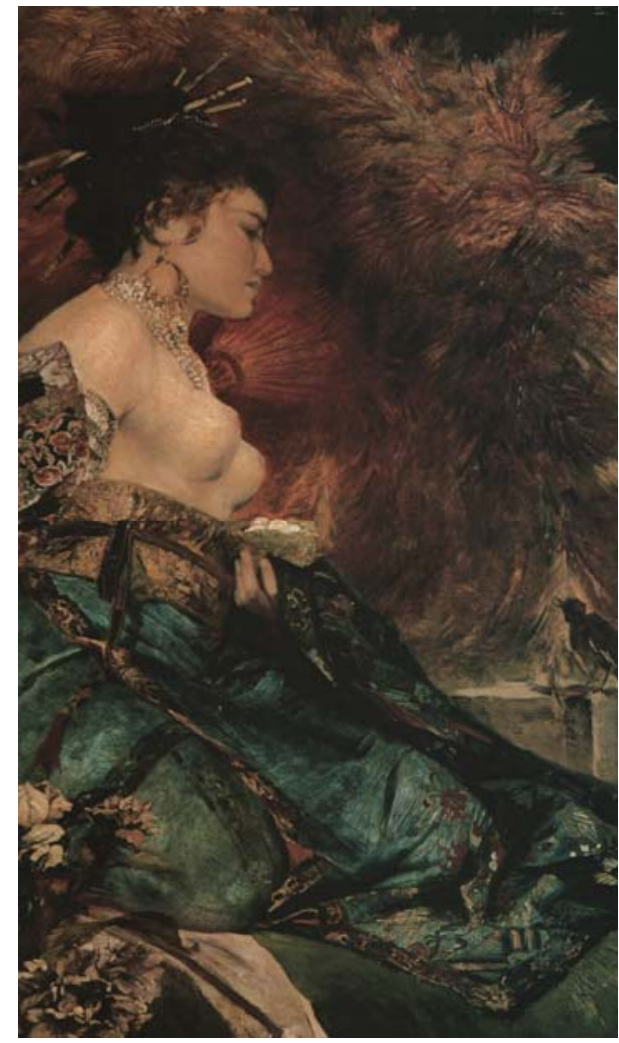

Figura 10: La Japonaise (Hans Makart), 1875 [p.125].

A palavra gueixa significa literalmente "pessoa da arte, artista", e ela foi originalmente usada para designar comediantes e músicos que se apresentavam em banquetes e festas particulares no século XVII. Assim, as primeiras gueixas não eram mulheres, mas homens. Os otoko-geisha (artistas masculinos) eram especializados em entreter pequenas platéias em festas, dançando, cantando, contando histórias e piadas. Como os palcos estavam proibidos às mulheres, as festas privadas tornaram-se os únicos lugares onde as mulheres podiam tocar música, dançar e cantar, e assim surgiram as onnageisha (artistas femininas).

Em um trecho do filme Memórias de uma Gueixa, a mestra dirige-se à aprendiz dizendo: "Lembre-se Chiyo: Gueixas não são cortesãs e também não são esposas. Vendemos nossas habilidades, não nossos corpos. Criamos um 
mundo secreto no lugar onde há apenas beleza. A palavra gueixa significa artista, e ser uma gueixa é ser julgada como uma obra de arte ambulante".

Essa figura mítica tornou-se tão popular na Europa no final do século $\mathrm{XIX}$ e início do século $\mathrm{XX}$, que passou a protagonizar além de pinturas e as artes plásticas em geral, peças teatrais, musicais e ópera. Na Figura 11, temos o cartaz de Dudley Hardy do musical The Geisha de 1896, produzido pela George Edwarde's Company e estreado no Gaiety Theatre, em Londres. Mas, a gueixa ultrapassa as bordas continentais, do tempo, quando incorpora a Madame Butterfly de Puccini (Figura 12). Não há nenhum grande teatro de ópera que não conste as inúmeras récitas dessa ópera tão aclamada e grandiosa, reconhecida por vasto público.

As origens desse enredo se devem a inúmeros autores que se deliciaram por essa exótica personagem. Pierre Loti (1850-1923) era um autor francês de romances em ambientes exóticos. Suas passagens por esses lugares - graças ao seu trabalho como oficial da marinha - inspiraram inúmeras obras. Dentre elas, Madame Chrysantheme, escrito em 1887, cujo cenário é o Japão. Em 1898, John Luther Long escreve o conto Madame Butterfly. Mas é David Belasco (1853-1931) que escreve a peça Madame Butterfly mantendo em linhas gerais o enredo de Long fazendo modificações para enfatizar o caráter dramático. É ele que insere o trágico suicídio de Butterfly, por exemplo. Giacomo Puccini estava em Londres para a estréia de sua ópera Tosca no Covent Garden quando ocorreu a estréia dessa peça teatral. E é essa peça que inspira Puccini a compor a sua Madame Butterfly - estreada no dia 17 de fevereiro de 1904, no Scala de Milão. 


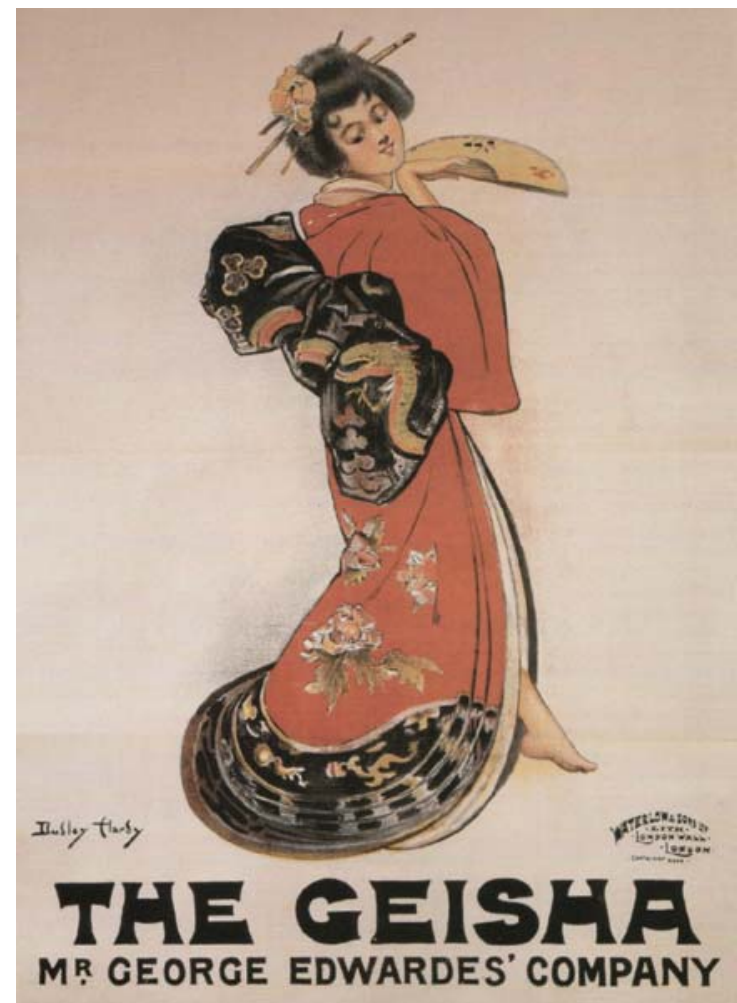

Figura 11: The Geisha (Dudley Hardy), 1896.

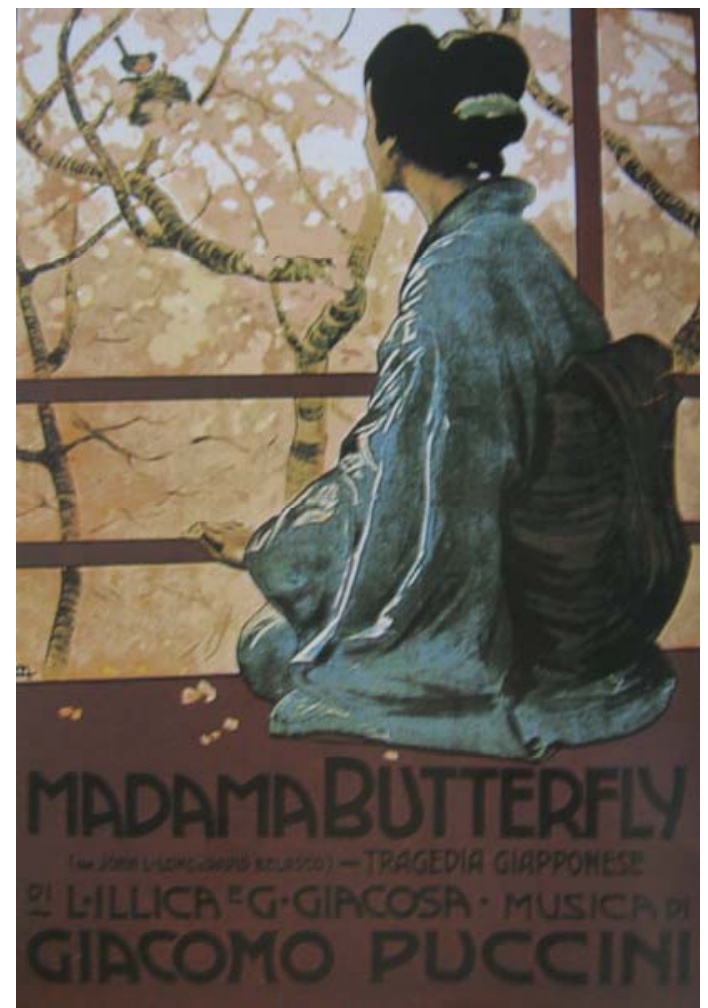

Figura 12: Madama Butterfly, 1904.

São esses ares intensos em torno do exótico da gueixa que cruzam oceanos inspirando até mesmo Villa-Lobos.

\subsection{Japonêsas de Heitor Villa-Lobos}

O poeta de Japonêsas, Luís Guimarães Filho, diplomata e cronista, nasceu no Rio de Janeiro, em 1878, e faleceu em Petrópolis, em 1940. Estudou na Universidade de Coimbra, onde recebeu o grau de bacharel em Filosofia, em 1895. Seguindo o exemplo do pai, Luís Guimarães, ingressou na carreira diplomática e viajou o mundo para cumprir as missões governamentais, inclusive para Tóquio e Pequim, onde vivenciou essa atmosfera oriental. Em Versos Íntimos, publicado em 1894, revelou-se um 
lírico, de expressão simbolista, e essa feição confirmou-se nas obras subsequentes. Seu livro de crônicas Samurais e Mandarins, publicado em 1912, logrou grande êxito literário. Foi membro da Academia Brasileira de Letras desde 1917.

É ainda em 1912, que Villa-Lobos, curioso e interessado nos movimentos provenientes da Europa, escolhe o poema Japonêsas desse poeta para compor a sua obra. Eis o poema:

\section{Japonêsas}

Oh! Gheishas!

Bonecas vivas

De vestidos molticôres,

Sois lindas, frageis, esquivas

Como os gatos e os amôres,

Tende olhos zombadôres

$E$ atitudes pensativas,

Ora sois jarros de flôres

Ora sois pombas captivas

A noite,

Em doce abandono,

Moveis o alá do Kimono

Ao triste som das guitarras.

O chá fumega na esteira

E na sombra hospitaleira

Morrem de frio as cigarras.

Villa-Lobos, com 25 anos em 1912, já havia composto Cânticos Sertanejos para orquestra, Suíte Popular Brasileira para violão, Tristorosa para piano, Trio $n^{\circ} 1$ para piano, violino e violoncelo e estava compondo a ópera Izaht (fusão de duas óperas anteriores - Aglaia e Elisa) e as Suites Infantis para piano. Tinha feito algumas viagens pelo Brasil em busca de sonoridades. É provável que essa obra tenha sido uma experimentação composicional na consolidação de uma linguagem própria, considerando o ano em que foi composta, principalmente porque foi nesse período que Villa-Lobos entrou em contato com a música de Debussy tão ornamentada de sabores orientais. 
A obra contempla 25 compassos. Apesar de não possuir uma tonalidade predominante, a canção inicia e termina em Dó maior (Figura 13).

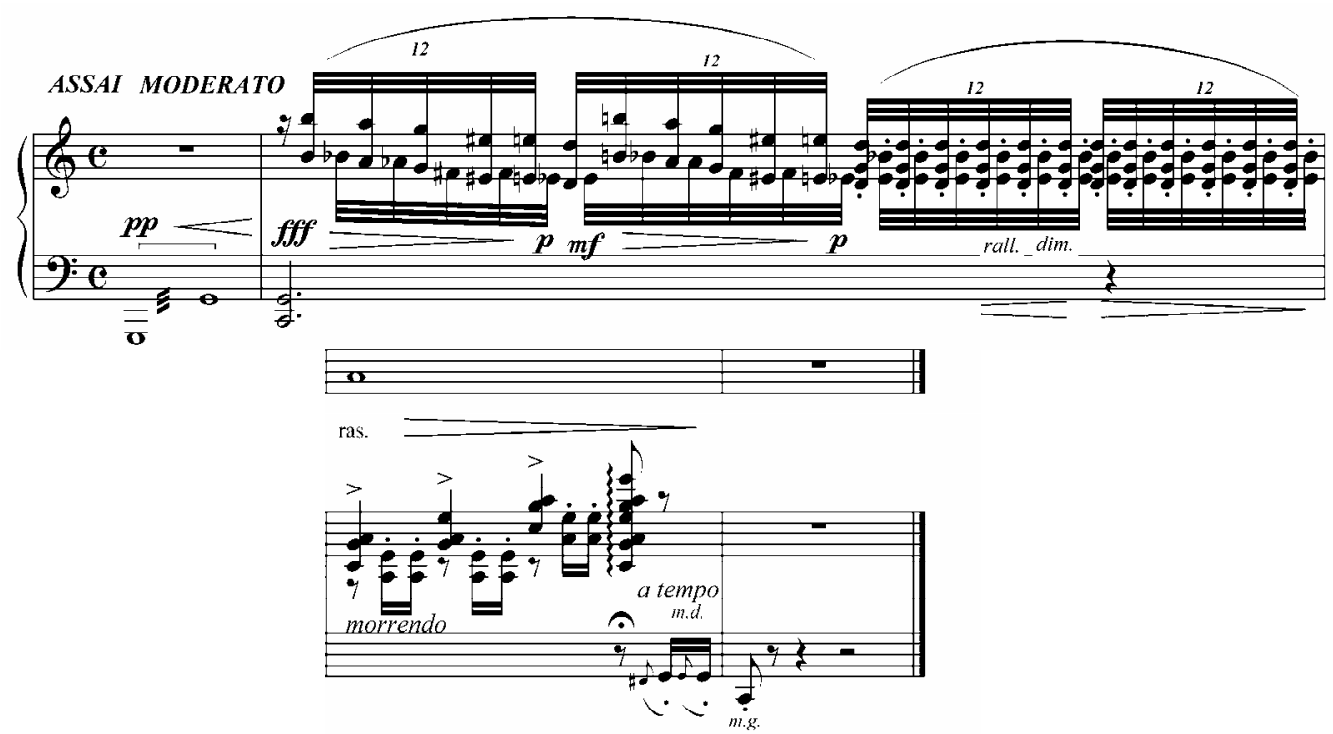

Figura 13: Compassos 1, 2, 24 e 25 de Japonêsas (Villa-Lobos).

Uma sequência descendente de cromatismos é utilizada nos dois primeiros tempos do compasso 2 - como mostra a Figura 14 - na introdução elaborada para o piano e também na melodia entoada pelo canto nos compassos 6, 7 e 8 na frase "Sois lindas, frágeis, esquivas como os gatos". 

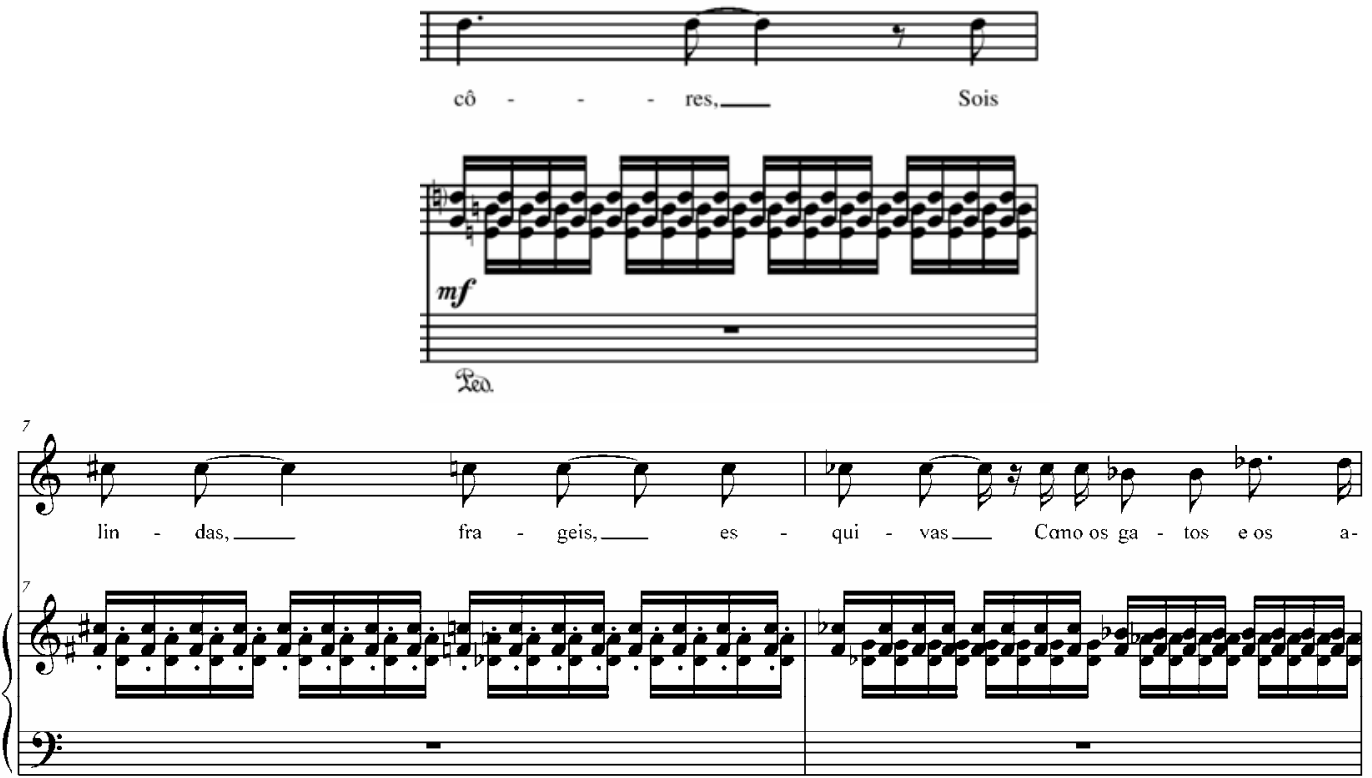

Figura 14: Compassos 6, 7 e 8 de Japonêsas (Villa-Lobos).

Villa-Lobos para criar, a seu modo, essa atmosfera nipônica, utiliza certos aspectos sonoros que caracterizam esse ambiente. O pentatonismo é um dos elementos utilizados e aparece nas frases melódicas dos compassos de 12 a 15 e 20 a 24. A frase melódica pentatônica da voz dos compassos de 12 a 15 é sobre o verso "Ora sois jarros de flores, ora sois pombas cativas". Composta pelas notas So \#, Lá \#, Si, Do \#, Ré \# (Figura 15). 

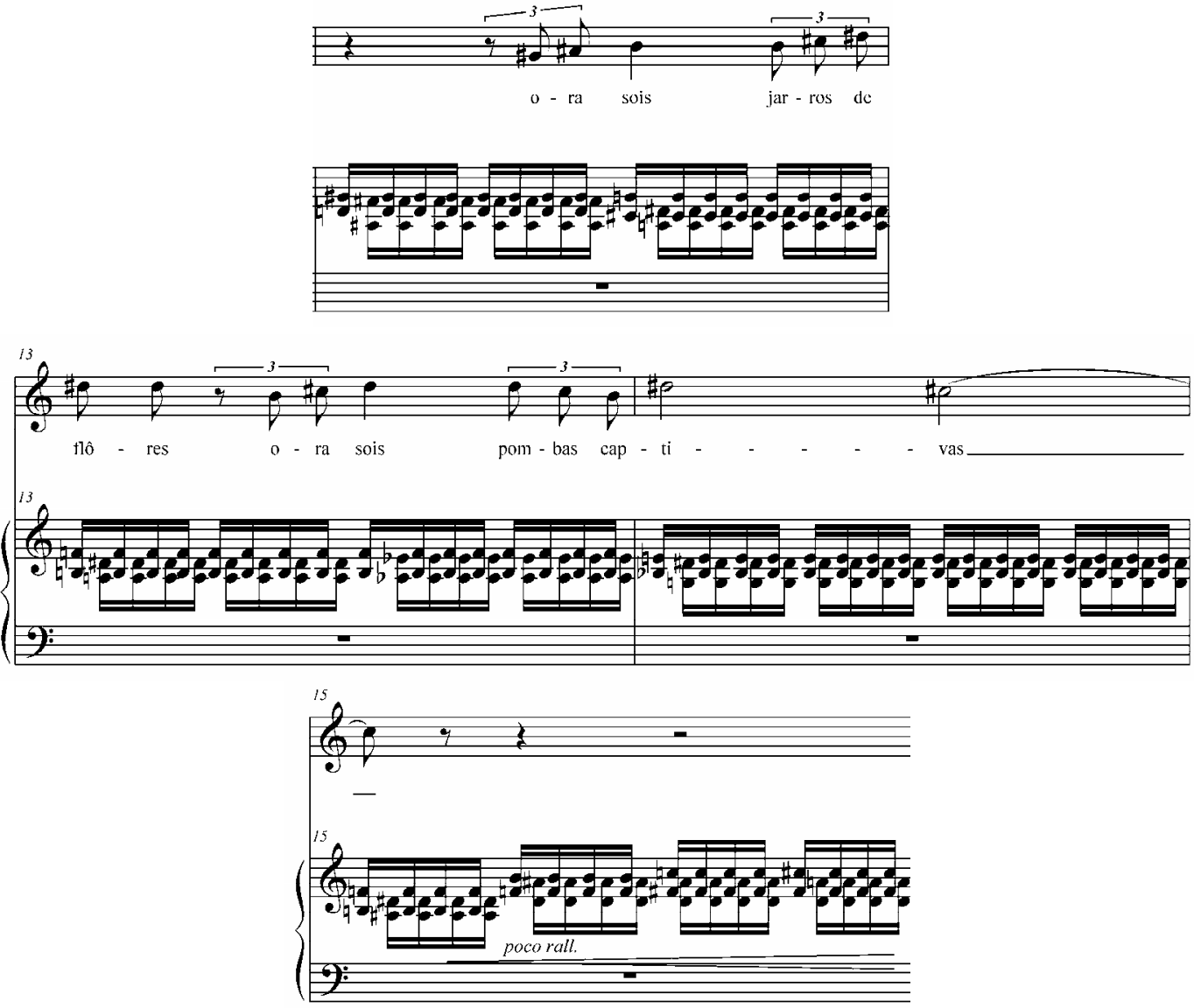

Figura 15: Compassos 12 a 15 de Japonêsas (Villa-Lobos).

Dos compassos de 20 a 24, podemos identificar dois grupos pentatônicos na sequência: o grupo que compreende as notas Lá \#, Si, Do \#, Ré, Mi e o outro com as notas Ré, Do \#, Si, Lá, Sol (Figura 16). 

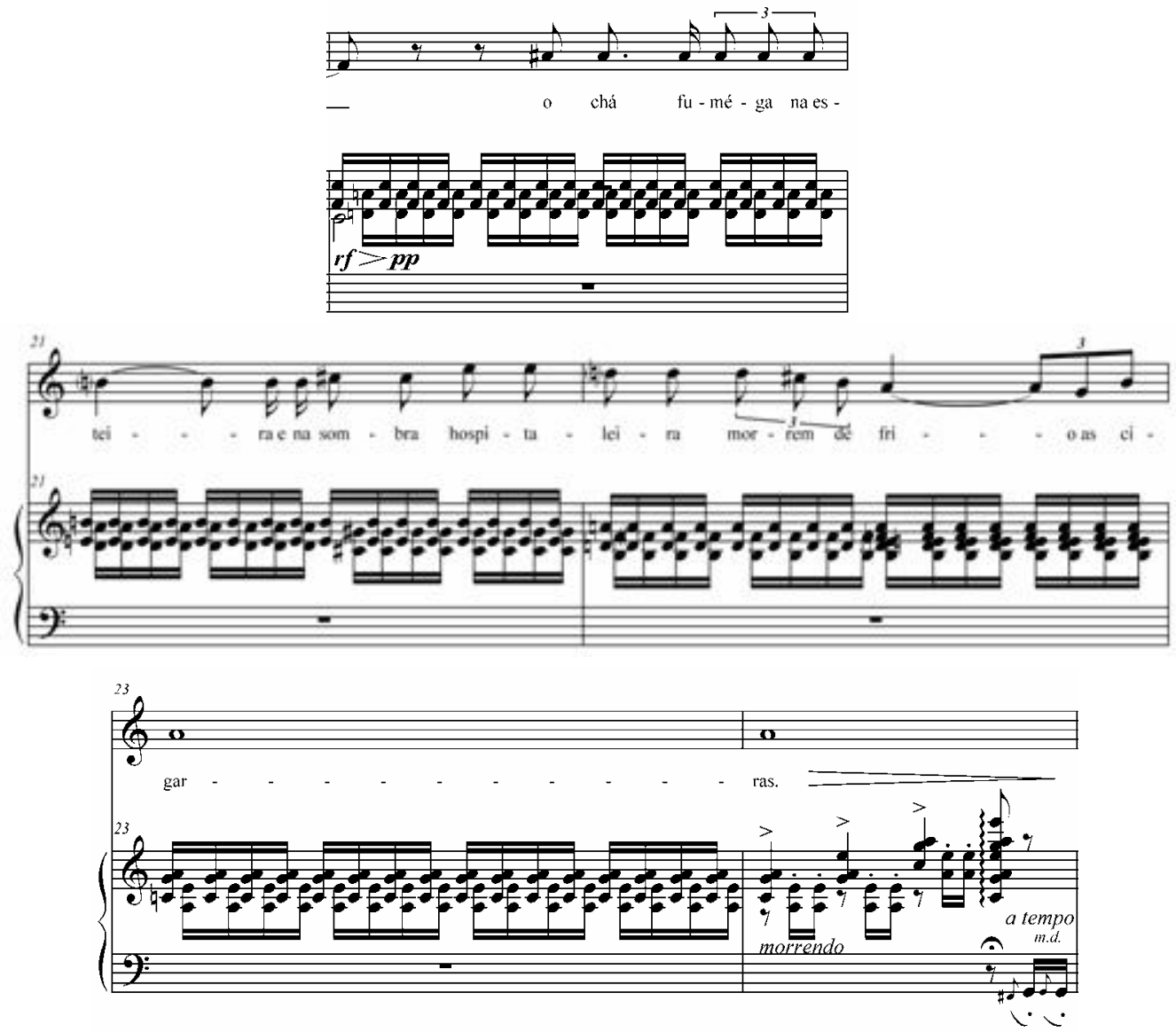

Figura 16: Compassos 20 a 24 de Japonêsas (Villa-Lobos).

Em Japonêsas, Villa-Lobos tece a sonoridade com sequências pentatônicas e quasi-pentatônicas na linha vocal. Há vários conjuntos de quatro notas que ora acrescentada mais uma, ambienta o caráter oriental com sutileza. Esse conjunto de quatro notas prevalece, tanto na melodia quanto no acompanhamento do piano. O piano é composto de sobreposição de quintas vazias (sem as terças), em ostinato, sugerindo uma estrutura baseada na repetição. A melodia flutua sobre a densa textura do acompanhamento que não apresenta tempos fortes na cabeça do compasso. As tercinas na melodia produzem um contraponto com o baixo e têm, portanto, maior liberdade na sua condução, enquanto o ostinato se mantém no acompanhamento. Villa-Lobos, talvez à maneira empírica de Debussy, tenha tentado evidenciar a força criativa do movimento Japonisme - mesmo sem ter tido, provavelmente, qualquer (cons)ciência desse conceito. 
CAPÍTULO 3: O mar de Suzu 


\subsection{Imagens japonesas da natureza}

A canção nasce da fusão do poema com a música, senão é uma "canção sem palavras", ou um vocalize, como já anteriormente mencionado. Kimball cita assim sobre essa fusão lembrando-se da erupção de imagens que evocam:

Nossa compreensão da arte da canção é estimulada pelas imagens da canção que o compositor cria com palavras, melodias, harmonias e ritmos. Todas as imagens do poema se fundem com as imagens da música criando uma imagem distinta da canção - uma singular combinação de palavra e som, poesia e música (KIMBALL, 2006, p. $1)^{11}$

Do final do século XVIII ao início do século XIX houve uma efervescência literária (Sturm und Drang) na Alemanha. Contudo, Franz Joseph Haydn e Wolfgang Amadeus Mozart já haviam quebrado a forte tendência anterior que preconizava o repertório instrumental com suas óperas clássicas. Logo a seguir, com Franz Schubert, o estabelecimento do Lied, enquanto novo gênero, ocorre num momento em que livros com coletâneas de canções populares estavam na moda $^{12}$. Essa renovação da palavra escrita facilitou a expressão musical de estados emocionais, particularmente quando o sentimento tem que ser expresso por meio da música. Com novo vigor, textos literários genuínos inspiraram a música e passaram a ser incorporados nas canções.

Robert Schumann determinou a igualdade de importância para a literatura e a música em suas composições, pois tinha a visão do poético em

\footnotetext{
${ }^{11}$ Our understanding of the song's art is stimulated by the images in the song, which composers create with words, melodies, harmonies, and rhythms. All the images of the poem merge with the images in the music, creating the distinctive overall images of the song - a unique blend of word and sound, poetry and music.

${ }^{12}$ Exemplo disto temos na publicação de uma então inédita coleção de música popular brasileira (oito modinhas para canto e piano, cantos indígenas para canto sem acompanhamento e um lundu instrumental também sem acompanhamento) em Munique, no ano de 1823, pelos naturalistas bávaros Von Martius e Von Spix, como resultado de suas "viagens filosóficas" (expedição de pesquisa) através de diversas regiões do Brasil (de 1817 a 1820). Com essa publicação, de certa forma, o Brasil se insere de maneira inequívoca na história do Lied desde seus primórdios.
} 
termos de intensificação artística que não implica na dependência da música sobre o texto, mas na igualdade entre o texto e a música, onde ora a música se transforma em texto, ora o texto é música - por sorte, tendo em vista a utilização de poemas de grandes poetas, como Heinrich Heine.

No Romantismo primordial alemão, assim que o mundo interno da deutsche Innerlichkeit (interioridade alemã) fez deslumbrar ao poeta toda a riqueza de temas e imagens, a natureza exerce o papel de protagonista no cenário centrado no submundo do "eu". Segundo o estudioso da literatura alemã Ulrich Christoffel:

O espírito se torna mais vivo no reconhecimento do prazer através da sensação interna. Um tom profundo e único da sensação e da vida interiorizada ressoa em todas as obras espirituais e artísticas de um povo e em todos os tempos. Esta melodia se revigora de uma maneira sempre nova em todas as canções, imagens, quadros, formas, configurações e pensamentos, encontrando seu eco em cada performance $^{13}$ (CHRISTOFFEL, 1940, Prefácio).

Na mesma herança romântica, muitas das imagens geradas através das canções aqui estudadas são evocações ao mundo da natureza com seus elementos diversos e forças conflitantes.

O mundo natural continha uma vasta disposição de objetos naturais, criaturas e sons que proporcionaram ao poeta tanto uma atmosfera para sentir e perceber intensamente como uma paisagem para devanear e lutar. (...) O poeta sensível estava vulnerável para a natureza e assim estava perspicazmente atento para os mistérios e variantes da natureza, incluindo como a natureza mudava com as estações e com o decorrer do dia. Ademais, muita poesia está centrada no momento de mudança ao longo do dia, por exemplo, o cair da tarde ou o alvorecer inspiraram a sensibilidade do poeta na sua forma mais elevada ${ }^{14}$ (STEIN; SPILLMAN, 1996, p. 8).

\footnotetext{
${ }^{13}$ Der Geist wird heiter in der Erkenntnis des Gemütes und das Auge klarer durch die innerliche Empfindung. Durch alle geistigen und künstlerischen Werke eines Volkes schwingt durch alle Zeiten hindurch ein einziger Grundton des Empfindens und innerlichen Lebens und die diese Melodie verlebendigt sich in allen Liedern, Bildern, Domen, Gestalten und Gedanken auf neue Weise und findet ihr Echo wieder in jedem Gemüt, das die Gedanken und Bilder in sich aufnimmt.

${ }^{14}$ The natural world contained a wide array of natural objects, creatures, and sounds that provided the poet with both an atmosphere in which to feel and sense vividly and a landscape in which to wander and struggle. (...) The sensitive poet was vulnerable to nature and thus was acutely aware of nature's mysteries and variabilities, including how nature changed with the seasons and the time of day. Further, much poetry centers around moments of change within The day, for example, where the anticipation of night at dusk or the release from night at dawn prompted the poet's sensitivity in heightened form.
} 
Sensíveis então às suas forças, os poetas românticos se inspiram na natureza - o que culminou com o surgimento do Lied - "foi a poesia lírica de paisagem e é sobretudo através da paisagem que a música se associa à arte e literatura românticas”. (ROSEN, 2000, p. 188).

Charles Rosen faz um esboço sobre o pensamento de Schiller na afirmação de que a música é uma imitação da natureza humana:

Há dois modos pelos quais a Natureza, sem a presença de criaturas vivas, pode se tornar um símbolo do humano: seja como representação dos sentimentos, seja como representação de idéias. Sentimentos não podem ser representados, de fato, por seus conteúdos Inhalt, mas apenas por suas formas, e existe, em geral, uma venerada e autêntica arte que não possui outro objeto senão essa forma de sentimentos. Essa arte é a música, e não importa 0 quanto a pintura de paisagem ou a poética de paisagem procedam musicalmente, a música é uma representação do poder do sentimento e, conseqüentemente, uma imitação da natureza humana. (ROSEN, 2000, p. 191).

No Ocidente, portanto, tendo em vista os rumos tomados pela religião cristã, podemos observar que a natureza e o homem se tornam elementos propensos à distinção em categorias distintas. Daisetz Taitaro Suzuki (1870-1966), grande difusor do Zen Budismo para o Ocidente, define no contexto ocidental uma certa "dicotomia natureza-homem", onde o homem assume o papel de conquistador da natureza, como se ela lhe fosse alheia (SUZUKI, 2006, p. 276-283).

Por outro lado, no Oriente, tendo em vista suas tradições religiosas (tanto do xintoísmo como do budismo), a natureza e o homem se encontram sempre já integrados numa relação de unidade indissociável, através de um conceito amplo de natureza, compreendida enquanto totalidade biológica, físico-química e

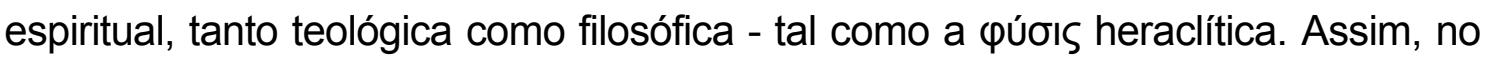
Oriente, se o poeta se refere à chuva, é a sua própria alma que chora. Quando as cerejeiras florescem, é a própria vida ou o amor que surge.

De volta ao romantismo, muito embora o poeta procure se aproximar da natureza, ele ainda não a incorpora enquanto totalidade. Como exemplo, podemos verificar primeiramente os versos da canção An die ferne Geliebte ( $A$ amada distante), Op. 98, de Beethoven e poema de Aloys Jeitteles: 
Sobre a colina me sento

Contemplando a terra azul de névoa

Mirando os pastos longínquos

Em que te encontrei, minha amada.

Para longe de ti fui afastado

Separando-nos estão montanhas e vales

Entre nós e nossa paz

Nossa alegria e nosso sofrimento ${ }^{15}$.

(ROSEN, 2000, p. 246)

A natureza é também a principal fonte de inspiração para expressar sentimentos na arte japonesa. No entanto, isso vai além do conceito de beleza, sendo parte integral também dos valores religiosos. Suzuki afirma ainda que "a apreciação da beleza é, no fundo, religiosa, pois sem ser religiosa não se pode detectar e deleitar o que é genuinamente bela"16 (ASQUITH; KALLAND, 2004, p. 2).

A estreita relação entre a apreciação estética da natureza e a religião é observada no xintoísmo (a religião primitiva japonesa) onde o kami (divindade) se apropria de elementos da natureza, tais como o sol, a lua, as montanhas, pedras, árvores, os córregos, as flores, os animais e até pessoas. De fato, de acordo com a mitologia japonesa, os fenômenos naturais descendem das deidades. Em certo sentido, a natureza é ela mesma divina e representa kami. Essa estreita relação entre homem, kami e [os elementos da] natureza está no ethos religioso do antigo Japão e influenciou também profundamente o budismo japonês $^{17}$ (ASQUITH; KALLAND, 2004, p. 2).

\footnotetext{
${ }^{15}$ Auf dem Hügel sitz ich spähend In das blaue Nebelland Nach den fernen Triften sehend Wo ich dich, Geliebte, fand.

Weit bin ich von dir geschieden

Trenned liegen Berg und Thal

Zwischen uns unsre Frieden

Unserm Glück und uns'rer Qual.

${ }^{16}$ The appreciation of the beautiful is at bottom religious, for without being religious one cannot detect and enjoy what is genuinely beautiful.

${ }^{17}$ The close relation between an aesthetic appreciation of nature and the religious is, for example, observed in Shintō, where the kami (divinity) is believed to have taken abode in natural features that give people a feeling of awe or spirituality, such as the sun and moon, rocks, streams, old trees, caves, flowers, animals and people of special character or standing. Indeed, according to Japanese mythology, natural phenomena are themselves the offpring of deities.
} 
Tendo em vista a perspectiva de David Edward Shaner, estudioso das relações asiáticas com a natureza, o sagrado Buda é a própria natureza. Portanto, o homem, para adquirir sua salvação ou para trilhar a genuína existência humana, deve viver de acordo com a natureza. Essas crenças são particularmente poderosas em Shugendō, um movimento religioso sincrético formado por crenças xintoístas, taoístas e do budismo tântrico. Através de um treino espiritual (shugyō) como, por exemplo, ficar sob uma cachoeira semi congelada, escalar e peregrinar nas montanhas e outras práticas ascéticas, os praticantes buscam compreender a si mesmos através dos movimentos da natureza. ${ }^{18}$ (SHANER, 1989 apud ASQUITH; KALLAND, 2004, p. 3).

Isso pode implicar numa profunda identificação com a natureza. De acordo com Yuriko Saito (estudiosa da estética da natureza no Japão), os japoneses se identificam com a natureza de duas maneiras. Uma ela chama de identificação emocional. A outra é baseada na transitoriedade, tanto do homem como da natureza. Referindo-se à primeira, as emoções humanas encontram expressão nos objetos e fenômenos naturais (como neblina, chuva, uma montanha ou um sapo). Quanto à segunda, trata-se da efemeridade da natureza, originada na conviç̧ão de que natureza e homem são essencialmente o mesmo: ambos enraizados no mesmo princípio de existência ${ }^{19}$ (SAITO, 1985 apud ASQUITH; KALLAND, 2004, p. 3).

\footnotetext{
${ }^{18}$ The path to salvation for human beings - the path of genuine human existence - is to live entrusting to and in accord with nature, a nature which is identical to the sacred Buddha. These beliefs are particularly powerful in Shugendō, a syncretistic religious movement blending Shintō beliefs with those of Taoism and tantric Buddhism. Through spiritual training (shugyō) such as standing under the icy waterfalls, climbing mountains, going on pilgrimages and performing other austerities, the practioner seeks to 'enter into the very process of being that is nature itself'.

${ }^{19}$ This may imply profound identification with nature. According to Yuriko Saito, the Japanese finds identification with nature in two ways: one she calls emotional (or emotive) identification; the other is based upon the transience of both man and nature. Through the former, human emotions find expression in terms of natural objects and phenomena, be they dew, rain, a mountain or a frog. Through the latter, the transience of human life is associated with the transience of nature, which 'stems from the conviction that nature and man are essentially the same, rooted in the same principle of existence' (SAITO, 1985, P.248).
} 
Assim, diferentemente do poema na canção de Beethoven, acima citado, um haiku (gênero de poesia tradicional do Japão) do poeta japonês Hashin (1864-?) já dimensiona a relação integrada do homem com a natureza ${ }^{20}$ :

Sem céu, sem terra.

Nada. Flocos de neve.

Caem sem cessar.

\subsection{O movimento da poesia concreta ${ }^{21}$}

A natureza é a principal imagem dos poetas japoneses nos haiku e nos tanka. A própria estrutura da linguagem escrita - os ideogramas chineses desencadeia essa elaboração pictórica. O valor do ideograma, seu método e a função poética da linguagem interessaram aos poetas brasileiros Augusto de Campos (1931), Haroldo de Campos (1929-2003) e Décio Pignatari (1927), ao se depararem com dois ensaios ${ }^{22}$ : Chinese written character as a medium for poetry, do filósofo e pesquisador Ernest Francisco Fenollosa (1853-1908) que viveu no Japão, entre 1878 a 1890) e editado em 1936 por Ezra Pound (18851972); e Cinematographic principle and the ideogram (1929), do cineasta Sergei Mikhailovitch Eisenstein (1898-1948), significativamente dedicado aos colegas japoneses. Haroldo de Campos em seu livro Ideograma assim cita:

Fenollosa procurou descobrir, na análise intrínseca dos caracteres
ideográficos, as fontes do prazer estético que os textos de poesia
sino-japonesa lhe proporcionavam. Para tanto, exatamente porque o
objeto a estudar - a escrita chinesa - se apresentava como algo
extremamente distante dos padrões ocidentais (exibindo mesmo,
nesse sentido, pelo menos aparentemente, um hiato máximo com
relação às línguas fonético-alfabéticas) - Fenollosa propôs-se
investigar (como Jakobson depois, na sua "poesia da gramática")
aqueles "elementos universais de forma" que constituem a "poética" e

\footnotetext{
${ }^{20}$ Isto não quer dizer que não haja poemas no ocidente em que a natureza assuma papéis de sujeito, assim como não haja no oriente poemas em que o sujeito (homem) protagoniza o cenário.

${ }^{21} \mathrm{~A}$ maior parte do material sobre a poesia concreta brasileira - artigos publicados - foi gentilmente cedida pelo compositor Luiz Carlos Lessa Vinholes, cuja participação foi ativa neste movimento.

${ }^{22}$ Estes ensaios foram traduzidos por Heloysa de Lima Dantas e publicados em uma edição organizada por Haroldo de Campos no livro Ideograma pela EDUSP, em 2000 (quarta edição).
} 
o modo como tais elementos operariam nessa poesia peculiar e peregrina (CAMPOS, 2000, p. 41).

Assim, Augusto de Campos, Haroldo de Campos e Décio Pignatari fundaram, em 1952, o grupo Noigandres, palavra enigmática usada pelo trovador provençal Arnaut Daniel e que figurou no Canto XX, de Ezra Pound”, é um termo cujo significado nem os romancistas sabem explicar. Foi tomada como sinônimo de poesia em progresso, como lema de experimentação e pesquisa poética em equipe" (CAMPOS; PIGNATARI; CAMPOS, 2006, p. 259).

Através do grupo Noigandres, o movimento em torno da poesia concreta foi liderado por esses três poetas paulistanos, tendo influenciado alguns dos rumos da poesia brasileira, colocando idéias e autores em circulação e efetuando revisões do passado literário, e, por fim, retomando o diálogo modernista com os conceitos que pautaram a Semana de Arte Moderna de 1922.

O movimento da poesia concreta se inicia com a Exposição Nacional de Arte Contemporânea realizada no Museu de Arte Moderna de São Paulo, em dezembro de 1956, quando foi publicado o terceiro número da revista Noigandres. Um texto referencial para o movimento da poesia concreta foi lançado em 1958, junto com a revista Noigandres $n^{\circ} 4$, que incluía trabalhos dos irmãos Campos, de Décio Pignatari, Ronaldo Azeredo e José Lino Grünewald. Pedro Xisto (1901-1987) e Edgard Braga (1897-1985), mesmo não pertencendo ao Grupo Noigandres, alistaram-se também como poetas do concretismo (VINHOLES, 2007a, p. 1-2). Os anos de 1957 a 1960 marcam maior difusão da poesia concreta por todo o país.

O Grupo Noigandres e os poetas independentes Pedro Xisto e Edgard Braga editaram a revista Invenção. De publicação nacional e internacional do movimento e de suas variantes, e da então "vanguarda" da poesia em geral, o exemplar n 4 da revista Invenção, do início de 1965, pode ser considerado um dos mais importantes documentos entre as publicações de diferentes movimentos de poesia moderna no mundo contemporâneo. (VINHOLES, 2007b, p. 2). 
Ainda segundo Vinholes, no seu artigo Intercâmbio, Presença e Influência da Poesia Concreta Brasileira no Japão, Haroldo de Campos enviou a Katsue Kitasono (1902-1978) exemplares de Noigandres III (XII.56), revista/livro editada pelo grupo homônimo, na qual a expressão Poesia Concreta é usada como subtítulo e apresentando poemas concretos brasileiros e alemães.

\begin{abstract}
Haroldo de Campos apresentou a Kitasono o conceito da Poesia Concreta nos seguintes termos: "a poesia concreta ou ideogramática, como nós o chamamos, pretende criar um objeto em si, um objeto verbal, atento ao campo gráfico, às virtualidades do "visual-verbal" do seu veículo de comunicação, e a palavra desconectada de qualquer efeito subjetivo ou decorativo. O padrão formal do verso (inclui o verso livre) é deixado de lado como reminiscência artesanal. O conteúdo forming halt tem concisão, clareza, honestidade. A percepção da kanjificação do poema se apresenta não somente no nível verbal, mas no não verbal também"²3.
\end{abstract}

Na mesma carta, Haroldo de Campos ainda afirma que "nós estamos profundamente interessados na poesia japonesa, especialmente do tipo do VOU" ${ }^{24}$, e informou ainda que "uma antologia internacional estava sendo preparada, envolvendo o grupo de Gomringer e o nosso"; e ainda perguntou: "seria possível enviar-nos poemas traduzidos para o inglês do VOU?"; e prometeu: "talvez possamos fazer algumas versões em português e publicarmos no Suplemento Literário do Jornal do Brasil”. A antologia acima mencionada - Kleine Anthologie Konkreter Poesie - foi publicada no corpo da revista Spuirale (1960), dirigida por Eugen Gomringer, incluindo parte do poema Monotonia do espaço vazio (tanchōna kūkan) de Kitasono, traduzido por Haroldo de Campos.

\footnotetext{
${ }^{23}$ Concrete or ideogramic poetry, as we name it, aims to create an object of its own: a verbal-object; it is aware of graphic field the 'verbivoco-visual' virtualities of its medium, the word, disconnected of any subjective or decorative effect. The formal patterns of verse ('vers livre' included) is left aside: an artisanal reminiscence. The contents. 'formin halt'. Shortness. Clarity. Straight forwardness. 'Kanji fication of poem's perception: it appeals not only to verbal, but to nonverbal level of communication as well".

${ }^{24}$ We are deeply interested in Japanese poetry, especially of VOU kind (...) an international anthology is being prepared, embracing Gomringer's group and ours (...) it will be possible for you to send us English translations of VOU poems, specially yours? (...) we think we could perhaps manage to make a few Portuguese versions, to be published in Literary Supplement of Journal of Brazil.
} 
Assim, exposições como a histórica Semana Nacional de Poesia de Vanguarda (1963), organizada em Belo Horizonte, pelos poetas Affonso Avilla e Affonso Romano de Sant'Anna, suplementos literários dos jornais Correio Paulistano e O Estado de São Paulo, Jornal das Letras do Rio de Janeiro e a já mencionada revista Noigandres divulgaram a poesia concreta japonesa durante os anos 60 e 70 do século XX no Brasil.

\section{3. Ōtani Shōgakkō Ka, de Luiz Carlos Lessa Vinholes}

Em 1958, por intermédio de Haroldo de Campos, Luiz Carlos Lessa Vinholes (1933) conheceu Kitasono pessoalmente, protagonista do movimento surrealista japonês do grupo VOU - infelizmente não pudemos localizar as origens ou significado dessa sigla ou nome. Desde então, Vinholes veio mantendo intenso contato, não só com Kitasono, mas também com outras figuras de importância dos grupos de poesia da então "vanguarda", tais como o grupo Pan Poésie, liderado por Shūzo Iwamoto (1908-1975) - autor da letra do hino Ōtani Shōgakkō Ka - e a Associação para Estudos da Arte (ASA) sob a liderança de Seīchi Nīkuni (1925-1977).

Essa associação (ASA) foi criada em decorrência da Exposição Internacional de Poesia Concreta (julho de 1964), idealizada e realizada pelo próprio Vinholes no hall de entrada do Teatro Sogetsu Kaikan de Tóquio. A ASA foi fundada para estudo e divulgação da poesia concreta, inicialmente a brasileira e, numa fase posterior, a de países como França, Alemanha, Itália, Inglaterra e Estados Unidos. Vinholes é, portanto, membro fundador da ASA, cujas reuniões tiveram início em 1964 quando o grupo foi oficialmente constituído. Vinholes participou de quase todas as reuniões até junho de 1968. Voltou ainda a frequentá-las quando retornou ao Japão, em maio de 1974. Vinholes foi também o único estrangeiro a participar das reuniões dos membros do grupo VOU e traduziu várias poesias, além da antologia Kemuri no Chokusen (Reta da Fumaça), do próprio Kitasono, publicada pela revista Através (1982), pela Editora Fontes. 
É nesse contexto que atua Luiz Carlos Lessa Vinholes, compositor, poeta e adido encarregado do Setor Cultural das embaixadas do Brasil em Tóquio e Ottawa. É o único compositor estudado neste trabalho que teve um vínculo estreito com a cultura japonesa in loco. Seu percurso biográfico é entremeado com a própria história da música e da literatura brasileira nas décadas de 50 a 70 do século XX. Apesar desta tese não estar respaldada devidamente com a biografia dos compositores brasileiros, como justificado na introdução, abre-se uma exceção no caso do Vinholes, pelo profundo envolvimento que abarcou durante os quatorze anos que viveu no Japão.

Nascido em Pelotas-RS (1933), Vinholes iniciou alí mesmo seus estudos de música. Cantava no coro da Catedral e trabalhava como copista da Orquestra Sinfônica de Pelotas, ofício que o aproximou do repertório e da teoria musical. Em 1952, foi convidado por Koellreutter - que o conhecia pelas passagens por Pelotas para reger a Orquestra Sinfônica - para participar do Curso de Férias de Teresópolis. Trabalhou como secretário do diretor Koellreutter na Escola Livre de Música da Pró-Arte, em São Paulo, onde estudou canto, flauta e composição. Em 1957 recebeu bolsa do Governo japonês para estudar música tradicional japonesa em Tóquio. Ao chegar no Japão, além de estudar no Departamento de Música da Universidade de Tóquio, foi aceito no Departamento de Música do Palácio Imperial para estudar o gagaku, a música da corte japonesa. Na ocasião estudou o hichiriki (pequena flauta vertical) e o shō (órgão de boca), com os professores Sueyoshi Abe, considerado "tesouro intangível", e Hiroharu Sono. Entre 1958 e 1961, Vinholes é contratado pela Comissão de Compras da USIMINAS para trabalhar com os engenheiros brasileiros da empresa no Japão. Em abril de 1960, Vinholes organiza a primeira mostra de poesia concreta brasileira fora do Brasil, em Tóquio, evento de enorme repercussão (MAIA, 1999, p. 84). Várias outras mostras de poesia concreta foram organizadas pelo compositor até o ano de 1964, no Japão. É também relevante a sua atuação como poeta. Seu poema tempo/pó, por exemplo, saiu na primeira página do Jornal Asahi Shinbun (1960), cuja publicação foi comentada nos jornais de São Paulo, Rio de 
Janeiro, Porto Alegre e Pelotas. Atuou intensamente nas traduções dos poemas, tanto do português para o japonês, como do japonês para o português. Segundo o próprio Vinholes, sempre esteve interessado em formas econômicas, minimalistas e encontrou nos nomes femininos japoneses $o$ arcabouço formal de uma estrutura poética pequena. Suas obras, assim concebidas, foram publicadas na Revista da Academia Brasiliense de Letras (1992 e 2000) e resultaram na publicação da coleção de mini-poemas: menina só, polievroma (neologismo resultante do amálgama de pó e ma e li vro), pela Editora Masao Ōno (1994). Ainda como poeta convidado esteve no Festival da Palavra de Veneza (Festival Internacional de Poesia Contemporânea), em 1997, compartilhando a noite de abertura com Umberto Eco; no Festival Música Viva em Pietra Ligure (1997); e no Festival Internacional de Poesia em Mantova (1998).

Retomando suas atividades de compositor, em 1956, numa série de três conferências sob o título Uma Nova Tentativa de Estruturação Musical, expõe sua teoria de organização de células rítmico-melódicas batizada de TempoEspaço. Segundo Valério Costa, Vinholes buscou "novas estratégias composicionais que o liberassem, tanto de uma tradição tonal considerada caduca, quanto do formalismo exacerbado da técnica dodecafônica". Nessa teoria propõe uma "forma sistemática de tratar o material sonoro sem vinculá-lo diretamente a nenhum sistema pré-estabelecido" (COSTA, 2005, p. 7).

Sua Instrução 61 é estreada em Tóquio, em dezembro de 1961. Essa obra musical é considerada a primeira aleatória criada por um brasileiro. Segundo Costa,

Nesta obra os intérpretes tocam seguindo instruções impressas em cartões mostrados por membros da platéia. Tal procedimento seria utilizado posteriormente em Instrução 62 , no ano seguinte, e a liberdade do intérprete em interferir no resultado de suas músicas passou a ser uma constante, assim como em seu trabalho com poesia. Como compositor produziu, até 1964, diversas obras. Entre elas a peça Tempo-Espaço VI - Kasumi, que foi estreada no $1^{\circ}$ Festival internacional de Música Contemporânea de Osaka (COSTA, 2005, p. 7). 
Relevando seu trabalho de intercâmbio cultural no Japão proporcionado pelo emprego na USIMINAS, a Embaixada Brasileira em Tóquio acabou por contratá-lo para cuidar do Setor Cultural. Promoveu, então, edição de partituras de compositores brasileiros, antologias poéticas e traduções para o japonês de peças de teatro. Durante o ano de 1962, Vinholes apresentou um programa de rádio chamado Canta Brasil, dedicado à música e à poesia brasileira em Tóquio. Nesse mesmo ano, participou da fundação da Sociedade Internacional de Artes Plásticas e Audiovisuais, em Osaka.

Em 30 de junho de 1976, no jornal A Tribuna de Santos, Gilberto Mendes, comentando sobre as obras de Vinholes, referiu-se à Instrução 61, escrevendo: "Esta última obra é histórica, pois se trata da primeira obra aleatória por um compositor brasileiro". E completa:

\footnotetext{
Vinholes sempre foi um solitário indiferente às modas, às ondas nacionalistas - atualmente parece que estamos entrando numa razão por que sempre se manteve na sua, cuidando do desenvolvimento de sua linguagem, sua pesquisa. É um herdeiro espiritual do pensamento musical de Anton Webern, o grande mestre a Escola de Viena. Trabalha sua música com uma bem pensada economia de meios. E trabalha pouco, só quando reconhece que vale a pena comunica o que concebeu. Tal como Webern. Por isso já o chamei de compositor bissexto.
}

Seus 14 anos de permanência no Japão e as estadas na Coréia do Sul e China permitiram conhecer outras formas de organização do pensamento e do fazer musical possibilitando maior liberdade com relação aos conceitos e preceitos ocidentais. Cultiva então, a economia de meios de expressão, a concisão da linguagem e deu preferência ao tratamento pragmático do processo de criação. Suas obras têm curta duração e estrutura própria e independente. Mostra interesse por uma linguagem com indeterminação, cultivando aspectos aleatórios. Na nova técnica de composição musical, o Tempo-Espaço, as dicotomias e os dualismos, tanto do sistema tonal quanto das diversas formas de atonalidade são superados. O Tempo-Espaço é uma técnica de caráter contrapontístico, utilizada na maioria de suas obras, onde o 
silêncio é matéria estrutural e não meramente ausência de som (tal como aludiu Gilberto Mendes na referência a Webern).

Mas, o pequeno hino, tão singelo, não é aleatório, não é indeterminado, não está inserido na teoria Tempo-Espaço e não é dodecafônico. Indo de encontro ao compositor, podemos desvendar o sentido oculto que se encontra atrás das partituras.

É sempre instigante ir de encontro ao criador. "Criador" aqui no sentido mais amplo e variado. A história é permeada de buscas inusitadas em torno do "criador", quer seja através das religiões, das escavações arqueológicas, das contradições teológicas, das investigações culturais primitivas, do confronto entre as culturas e dos estudos filosóficos. Descobertas do processo da psique humana fundamentam o cerne da estrutura do modo de ser de um determinado indivíduo em torno da relação com seus pais, ou seja, seus "criadores". O "criador" é sempre um mito. O "criador" de uma música tenta, ainda que de forma precária, colocar em forma de notações musicais, a aura que envolve a sua obra. Portanto, o que se encontra oculto por trás das partituras é muito mais amplo, profundo e indizível do que a imaginação pode captar. Uma pequena partitura de poucos compassos, muitas vezes, pode proporcionar mais verbos que uma tese inteira. O silêncio na obra musical ou o espaço vazio de um poema pressupõem ainda, as mais variadas interpretações.

As histórias inusitadas de Vinholes se transbordam infinitamente, suas palavras pulsam a intensidade de seus afazeres realizados nos quatro cantos do mundo. É um sentir, aqui e agora, de todas as suas maquinações pueris de uma inocência nunca desvirginada.

É dessa natureza inocente que nasce o Ōtani Shōgakkō Ka (Hino oficial da Escola Primária Otani), da cidade de Suzu, província de Ishikawa (1962). A arte japonesa tem o estigma de sintetizar de forma magistral, uma gama de complexidades ontológicas. E é nesse contexto minimal, em dimensões variadas, que sua obra ecoa nas vozes infantis, cruza os oceanos e mares e sacode as estruturas diplomáticas entre os países propiciando fluxos intercambiais mais intensos. 
O canto no Japão atual é um dom intrínseco do ser humano, uma capacidade inerente à sobrevivência. O indivíduo que não canta chega a ser marginalizado pelos colegas. É assim que ganha notoriedade, o cantor e professor da Universidade de Mie, Tōru Yuba, com seu método de "cura" dos desafinados reintegrando esses no seio da sociedade. Isso se fundamenta na história do canto no Japão, disciplina tornada obrigatória desde as últimas décadas do século XIX. Não é por acaso que o karaokê surgiu no Japão - não obstante as suas precárias condições estéticas, tendo-se em vista o atual contexto musical da Indústria Cultural num mundo globalizado.

Em 1872, o ensino primário, antes limitado a uma classe privilegiada, tornou-se compulsório no Japão. O "exercício do canto" foi incluído no programa desse ensino, para o qual foram compostas canções infantis com o intuito de educar as crianças. A Revolução Meji (1868), que sucedeu a abertura dos portos (1854), marca o fim do isolacionismo de mais de dois séculos e meio e inaugura a entrada significativa do ocidente. $O$ Japão passa subitamente do feudalismo ao capitalismo (SUZUKI, 1995, p. 50) ${ }^{25}$. A modernização e a internacionalização desse período enfatizavam a educação, acumulando e valorizando conhecimentos adquiridos no exterior com o intuito de fortalecer a estrutura da nação.

Com a Restauração Meiji, a música tradicional japonesa, assim como a medicina, o vestuário, os samurais e outras tradições milenares, foram substituídos pelos costumes ocidentais. Mas, como a cultura japonesa não permite mudanças no conteúdo, apesar da transformação da forma, as canções, embora tenham assimilado a harmonia tonal no acompanhamento (e a tonalidade se torna incontornável, uma vez que se utiliza já o temperamento do piano e não mais as afinações dos instrumentos tradicionais), mantiveram em parte o canto pentatônico com seus contornos melódicos característicos. Mas nessa nova prática (do canto pentatônico com acompanhamento tonal de piano) não se encerra um parodoxo evidente? Como o teclado poderá preservar qualquer escala não temperada? Há como escapar de um

\footnotetext{
${ }^{25}$ SUZUKI (1995) As Expressões de Tratamento da Língua Japonesa. São Paulo: Editora da Universidade
} de São Paulo (p. 50). 
neofolclorismo generalizado se o piano é introduzido como base para o canto do Japão no século XX? Lembramos que neofolclorismo é um conhecido conceito stravinskyano para designar o repertório popular de tradição oral posto em partituras visando a execução em sala de concertos (STRAVINSKY, 1996, p. 26, 89-108). Não é por menos, que há muito tempo o Japão se tornou até um dos maiores produtores mundiais de pianos (com grandes fábricas como Yamaha e Kawai) - atendendo o mercado, tanto interno como externo.

Os poemas das canções japonesas com harmonia tonal retratam os sentimentos nostálgicos, característicos da alma japonesa nesse período que a sociedade se transforma abruptamente, deixando saudades do antigo feudalismo. O sentimento nostálgico é inerente ao ser humano, ou seja, é fundamentalmente ontológico. Ele evoca a terra natal, o paraíso perdido, as antigas relações de produção, o tempo que não volta jamais. Não se restringe naturalmente ao povo japonês. Portanto, primeiramente, canções estrangeiras (em geral alemãs, espanholas e norteamericanas) foram introduzidas no sistema educacional. E seus versos originais foram substituídos por japoneses com ditames morais que elucidavam a essência da alma japonesa, não obstante qualquer ingenuidade resultante. Em seguida, músicos tradicionais japoneses que possuíam algum tipo de conhecimento de música européia começaram a compor. Esperava-se que algo novo pudesse ser produzido com o estudo concomitante das músicas européia e tradicional japonesa. Todas essas canções com propósito educacional, contidas nos livros didáticos "Canções da Escola Primária", foram denominadas shōka.

Essas publicações influenciaram também os adultos, estimulando ainda muitos jovens a estudar música européia. Entretanto, durante esse período houve grupos de poetas japoneses insatisfeitos com o estilo literário das canções shōka, de escrita clássica ultrapassada. Essas refletiam a postura do governo em relação à educação, que via na música infantil um instrumento de doutrinação. Eles procuraram os compositores, dentre eles, Kōsaku Yamada, para criar canções que refletissem as palavras e os sentimentos das crianças. 
Instituíram então, dōyō - "canções infantis" - como uma reação contrária ao shōka.

Basicamente, não há diferença entre shōka e dōyō em se tratando de forma musical ocidental, a não ser em relação ao seu conteúdo textual, conforme supracitado. Além do mais, a forma coloquial de linguagem textual era predominante em $d \bar{o} y \bar{o}$, contrastando-se radicalmente com as formalidades do shōka.

A composição de dōyō era a única atividade musical ocidental do período, pois ainda não existiam orquestras, teatros, nem grupos de câmara, o que contribuiu para impulsionar a aquisição de pianos e órgãos com o propósito de educar as crianças.

A música tradicional japonesa é expressa sempre em uníssono ou monodia (com uma única linha melódica), o que a aproxima conceitualmente do universo do cantochão, mesmo que enriquecida pelos diversos timbres dos instrumentos - não obstante o caráter exclusivamente homofônico. Assim, com afinações não temperadas, sem uma voz (instrumento) grave enquanto fundamento da harmonia e ainda estando desprovida de qualquer princípio de contraponto, a tradição musical japonesa estava bem distante das práticas ocidentais grafocêntricas. Sua estrutura pode ser contrastada com a música ocidental de diversas maneiras. Enquanto a música ocidental - consideraremos a música tonal - possui uma estrutura musical complexa e autônoma, a música tradicional japonesa é construída habitualmente de acordo com os versos da canção. Entretanto, podemos dizer que, nela, o texto é o elemento primário, e a música em si desempenha apenas um papel secundário. Na música ocidental, motivos melódicos e rítmicos podem ser utilizados para desenvolver um tema e suas variações. Na música tradicional japonesa, esses motivos são praticamente inexistentes em virtude da subordinação da melodia às palavras.

No entanto, a maior parte dessas características da música vocal tradicional japonesa não pôde ser mantida nas canções após a harmonização tonal. O que permanece na canção japonesa, na maioria das vezes, após o processo de ocidentalização, é um certo pentatonismo melódico assim como o 
conteúdo literário. Mas como o povo japonês não abandona suas tradições em sua essência, podemos considerar que o desenvolvimento da canção infantil criou uma vertente paralela à música vocal tradicional.

E assim, compõem-se hinos escolares, tal como o hino de Vinholes, sem pentatonismos. Trata-se de um hino infantil tonal, em Ré maior. Sua curta duração totaliza 18 compassos em $2 / 4$, sendo a escrita a cappella a duas vozes mistas. As vozes são intercaladas, ou seja, uma voz canta e depois entra a outra na forma responsorial (perguntas e respostas) até o compasso 12 , quando ocorre a simultaneidade de vozes até o compasso 15. A partir do compasso 16 ocorre um uníssono até o final do hino, que possui três estrofes e ainda um estribilho em uníssono.

A letra é de Shūzo Iwamoto e aqui reproduzimos sua versão em português com tradução do próprio compositor:

Suzu no umi

Inochi afureru

Namini mukai

Nami yorimo tsuyoi

Bokura

Watashira

Tanoshiku aruku

Tanoshī gakkō

Ōtani shōgakkō
Kibishī kita

Chikara no kagiri

Sakende iru

Kaze ni mo makezu

Bokura

Watashira

Genki ni tatte

Tanoshī gakkō

Ōtani shōgakkō
Asu no nippon

Kata ni ninai

Mune hatte

Ashi nami soroete

Bokura

Watashira

Akaruku ayumu

Tanoshī gakkō

Ōtani shōgakkō
Mar de Suzu

Desperta a vida

Encarando as ondas

Mais forte do que as ondas

Nós, os meninos

Nós, as meninas

Caminhamos alegres

Escola alegre

Escola Primária Ohtani.
Vento norte severo

Ao limite das forças

Soltam as vozes

Nem ao vento soçobram

Nós, os meninos

Nós, as meninas

Fortes, de pé

Escola alegre

Escola Primária Ohtani.
O Japão de amanhã Levamos na garupa

De peito altivo

De passos certos

Nós, os meninos

Nós, as meninas

Andamos felizes

Escola alegre

Escola Primária Ohtani.

Ōtani Shōgakkō Ka (Hino da Escola Primária Ohtani) foi estreado em abril de 1962, com letra do poeta Shūzo Iwamoto. Segundo o próprio compositor, foi musicada com melodia que mescla a plasticidade de expressão 
japonesa com pequena referência ao ritmo sincopado característico das oralidades culturais brasileiras. A princípio, diz o compositor que teve uma certa resistência para aceitar o convite, entretanto, como o autor da poesia era um amigo, líder do movimento Pan Poésie, a poesia de "vanguarda" do Japão do século XX, acabou por deixar-se levar neste desafio. Veja na Figura 17, a foto do compositor com o poeta tirada em Tóquio em $1962^{26}$.

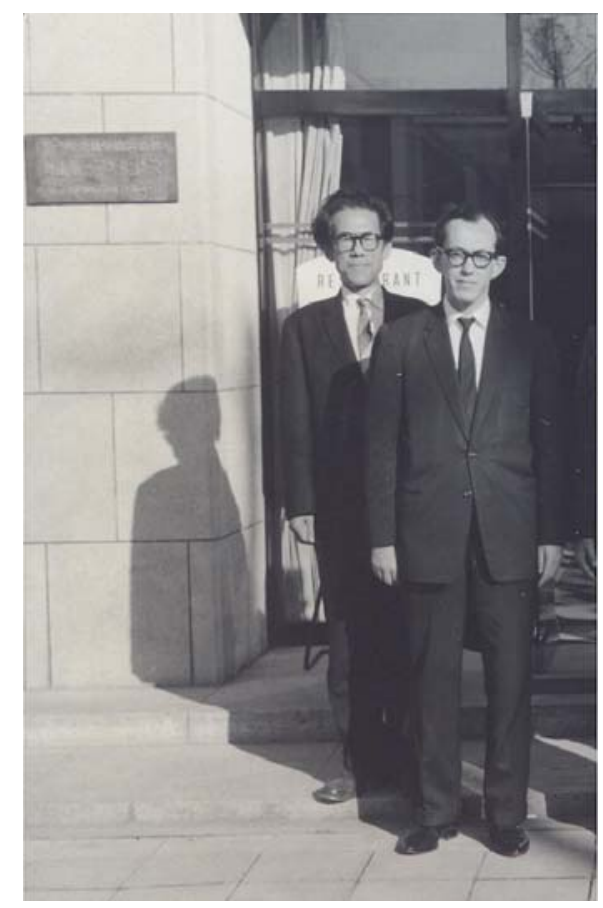

Figura 17: Vinholes e Shūzo Iwamoto.

O poeta Shūzo Iwamoto nasceu em Ujiyamada, na Província de Mie (1918). Estudou literatura clássica chinesa na Universidade Tōyo, formando-se em 1932. Juntamente como Yukio Haruyama e Katsue Kitasono, desde muito cedo juntou-se ao movimento modernista da literatura japonesa. Com esse, publicou o periódico Madame Blanche, pela Editora Bon-Shoten (1932 a 1934) e colaborou ainda nas revistas Hakushi (Papel Branco) e VOU, sigla utilizada por Kitasono e que nunca teve seu significado esclarecido. Tornando-se

\footnotetext{
${ }^{26}$ Todas as ilustrações concernentes a este capítulo foram gentilmente cedidas por Luiz Carlos Lessa Vinholes.
} 
independente, liderou o grupo Pan Poésie e publicou a revista homônima (de 1949 a 1960). O poeta e especialista em literatura japonesa, o estadunidense John Solt, afirma que a poesia de Shūzo Iwamoto "é um dos melhores versos modernos produzidos em japonês", pois "ele foi capaz de criar seu estilo próprio". Em 1987, a editora japonesa Blue Canyon Press publicou uma antologia reunindo toda a obra poética de Iwamoto tendo como editor o também poeta Yoshii Kawamura. Shūzo Iwamoto faleceu em Tóquio, em 9 de março de 1979. Segundo Vinholes, esse hino é um dos grandes êxitos da sua carreira como compositor, mas que não tem nada a ver com o que se conhece do seu trabalho, nem consta no seu catálogo de obras. "É algo muito simples, mas com um significado mais de fraternidade do que de valor musical". Foi o primeiro e único hino escolar japonês escrito por um estrangeiro. Vinholes teve o privilégio de conhecer a escola Ōtani da cidade de Suzu e ensaiar com as crianças. "Isto tudo em 1962. Parece que foi ontem", confessa. A seguir, na Figura 18, fotos que ilustram a visita e os ensaios de Vinholes com os alunos na escola primária.
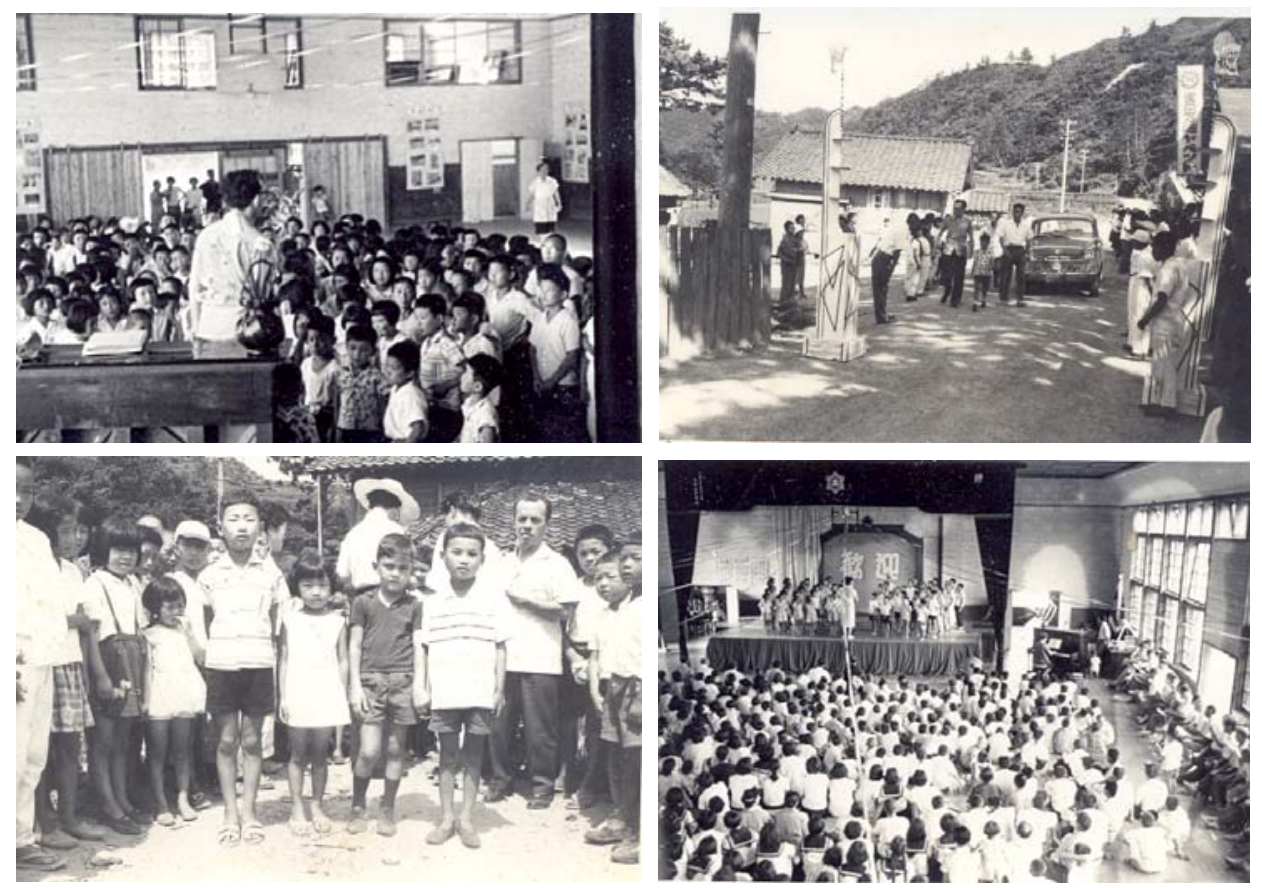

Figura 18: Vinholes com as crianças da Escola Primária Ōtani Shōgakkō. 
O jornal Correio do Povo, de Porto Alegre, em 15 de junho de 1967, publicou a reportagem $A$ Pequena História de um Hino, do jornalista Paulo Condini ( Figura 19).

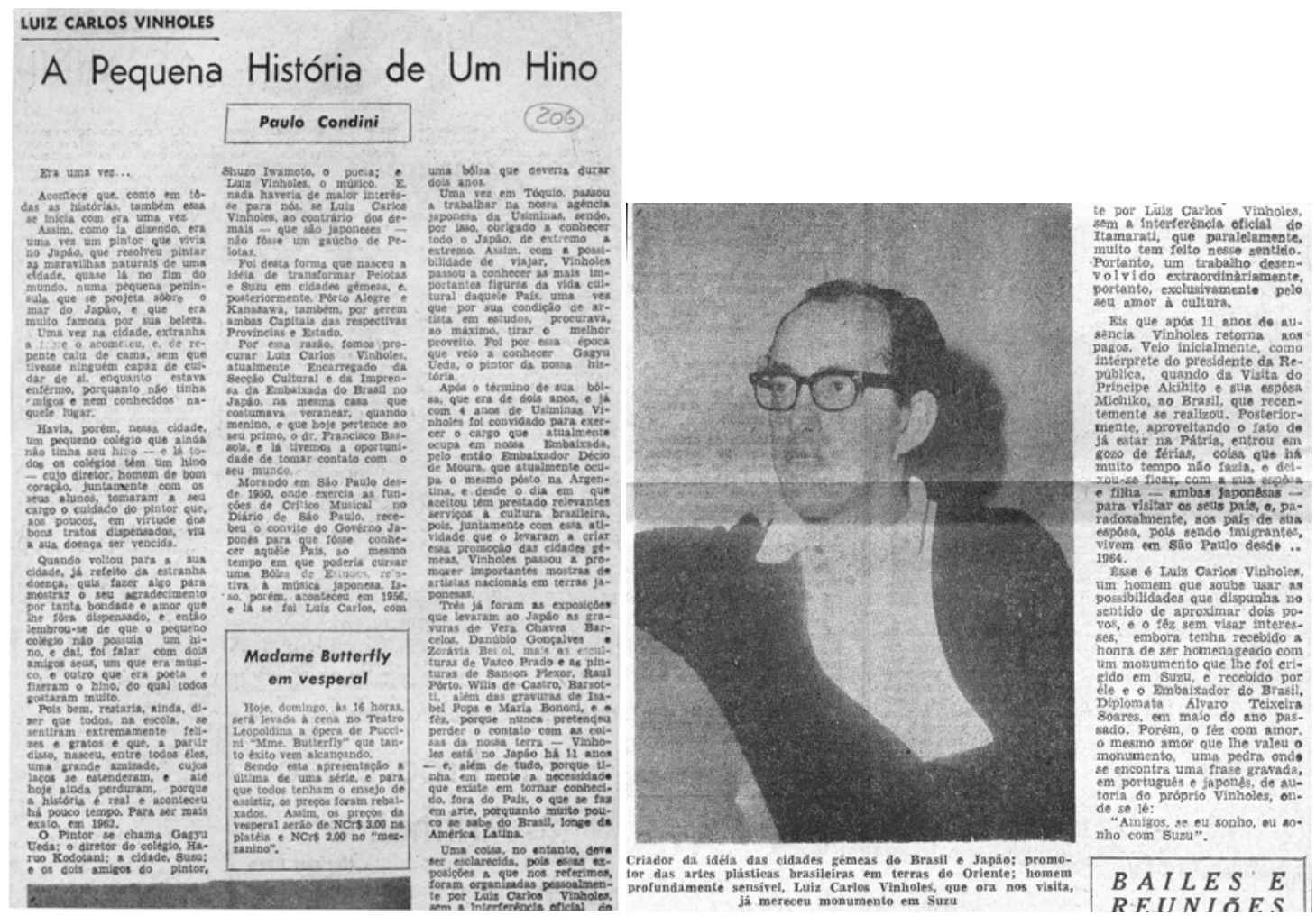

Figura 19: Jornal Correio do Povo.

Era uma vez...

Acontece que, como em todas as histórias, também essa se inicia com era uma vez.

Assim como ia dizendo, era uma vez um pintor que vivia no Japão, que resolveu pintar as maravilhas naturais de uma cidade, quase lá no fim do mundo, numa pequena península que se projeta sobre o Mar do Japão, e que era muito famosa por sua beleza.

Uma vez na cidade, estranha febre o acometeu, e, de repente caiu de cama, sem que tivesse ninguém capaz de cuidar de si, enquanto estava enfermo, porquanto não tinha amigos e nem conhecidos naquele lugar.

Havia, porém, nessa cidade, um pequeno colégio que ainda não tinha seu hino -e lá todos os colégios têm um hino - cujo diretor, homem de 
bom coração, juntamente com os seus alunos tomaram a seu cargo o cuidado do pintor que, aos poucos, em virtude dos bons tratos dispensados, viu a sua doença ser vencida.

Quando voltou para a sua cidade, já refeito da estranha doença, quis fazer algo para mostrar o seu agradecimento por tanta bondade e amor que lhe fora dispensado, e então se lembrou de que o pequeno colégio não possuía um hino, e daí, foi falar com dois amigos seus, um que era músico e outro que era poeta e fizeram o hino, do qual todos gostaram muito.

Pois bem, restaria, ainda, dizer que todos, na escola, se sentiram extremamente felizes e gratos e que, a partir disso, nasceu, entre todos eles, uma grande amizade, cujos laços se estenderam, e até hoje ainda perduram, porque a história é real e aconteceu há pouco tempo. Para ser mais exato, em 1962.

O pintor se chama Gagyu Ueda; o diretor do colégio, Haruo Kadoya; a cidade, Suzu; e os dois amigos do pintor, Shūzo Iwamoto, o poeta; e Vinholes, o músico. E, nada haveria de maior interesse para nós, se Vinholes, ao contrário dos demais - que são japoneses - não fosse um gaúcho de Pelotas. (...)

Um ano depois, as Câmaras Municipais das cidades de Suzu e Pelotas (cidade natal de Vinholes), por aprovação unânime, assinaram um acordo que as tornaram as primeiras cidades-irmãs entre o Brasil e o Japão. Eram prefeitos João Carlos Gastal e Riichiro Okamura. Não tardou para que os estudantes de ambas as cidades dessem início a uma intensa troca de correspondência que, coroando a dedicação de trinta anos de relacionamento fraterno supervisionado pelas professoras Terezinha Mallmann Louzada e Akiko Naka, resultou na visita de um grupo de dez estudantes japoneses e autoridades políticas a Pelotas, em dezembro de 1992.

E 1967, também por intermediação de Vinholes, em contatos com o prefeito Ildo Mengheti, Porto Alegre e Kanazawa - capitais do Estado do Rio Grande do Sul e da Província de Ishikawa, onde estão localizadas Pelotas e Suzu, celebraram também um elo de irmandade, seguindo o exemplo dessas primeiras cidades-irmãs entre o Brasil e o Japão.

Hoje são inúmeros os eventos promovidos em ambos os países em decorrência do relacionamento fraterno entre cidades-irmãs brasileiras e japonesas. Seus objetivos são os mais variados, promovendo, entre outros, o intercâmbio cultural e artístico entre seus munícipes. 
Assim, é o Pequeno Hino de Vinholes. Sem bordas. Sem pentatonismos. Talvez, a mais nipônica de todas as obras investigadas neste trabalho, feito um "vazio" do jardim Zen, caracterizado pela simplicidade, nudez, singularidade ocultado pelo silêncio inquieto, perturbador, inovador da voz interna do autor. Vinholes, na sua função diplomática, soube colocar-se naturalmente, sem resistência, no lugar do outro, sem deixar de ser ele mesmo no processo de composição desse pequeno hino, Ōtani Shōgakkō ka (Figura 20).

\section{大谷小学校歌}

岩本修蔵作言同

L. C. $\rightarrow \because=3-L x$ 作曲
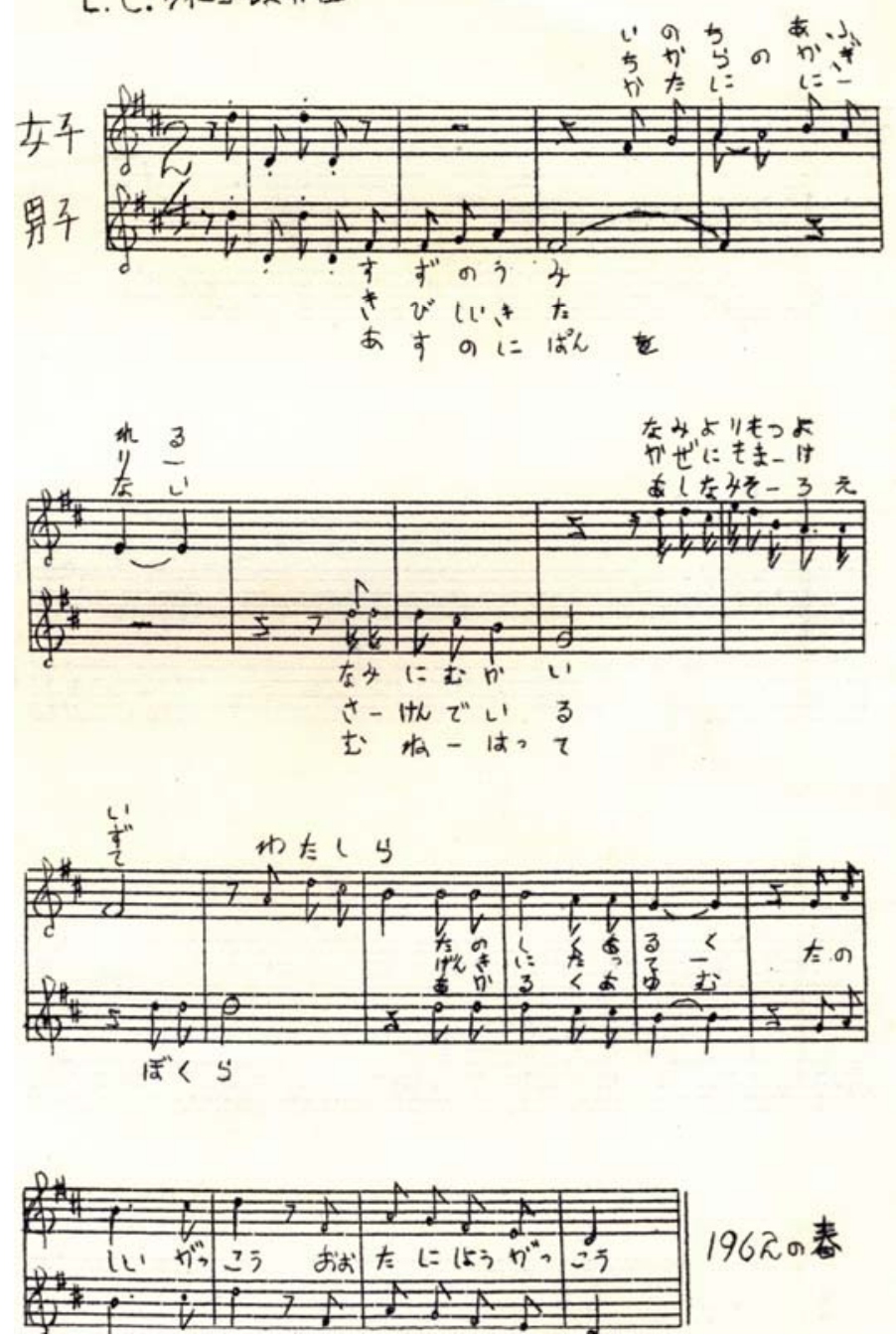

Figura 20: Partitura manuscrita do hino. 
CAPÍTULO 4: Um punhado de areia 


\subsection{As classes sociais e o pentatonismo}

Pode-se afirmar que uma das características fundamentais da música tradicional japonesa é o predomínio da música vocal. A estreita ligação com a literatura pode ser observada nos teatros Kabuki, Ningyō Jōruri (teatro de bonecos), Nō, Kyōgen ou nas danças tradicionais japonesas. Cada uma dessas artes está vinculada a uma determinada casta social. Os teatros Kabuki e Ningyō Jōruri pertencem à casta dos agricultores, artesãos e comerciantes, enquanto os teatros $N o \overline{~ e ~ K y o ̄ g e n ~ a ̀ ~ c a s t a ~ d o s ~ s a m u r a i s, ~ c o n s i d e r a d o s ~}$ superiores. No período de mais de duzentos e cinquenta anos em que o Japão ficou isolado do mundo, foi liderado pelos samurais com a política baseada no militarismo e no feudalismo. Nesse sistema, as castas sociais foram divididas em:

1) Castas dos Samurais: o topo da escala social por lutar e morrer pelos seus senhores na defesa de seus feudos.

2) Castas dos Agricultores: tinha importância por produzir alimentos.

3) Castas dos Artesãos: incluía os artesãos, que produziam os utensílios e ornamentos, médicos e sacerdotes.

4) Castas dos Comerciantes: os últimos na escala social por serem considerados, na época, somente interessados em adquirir lucro, sem nada produzir.

Assim, os samurais distinguiam-se das outras castas, isto é, a dos agricultores, dos artesãos e dos comerciantes. Consideravam-nos como Shōnin (mercadores). A arte dos samurais e a arte dos Shōnin, dessa forma, adquirem características diferenciadas nesse período de isolamento imposto pelo xogunato. O longo período sem guerras favoreceu o florescimento das mais refinadas artes da cultura japonesa. Dentre os Shōnin surgiram artes tais 
como o Haiku (poema de 17 sílabas, extraído do tanka, pois consiste somente das três primeiras unidades 5-7-5), Ikebana (arranjos de flores), Ukiyo-e (pinturas em madeiras esculpidas e coloridas e depois impressas no papel), cerimônia do chá e o teatro Kabuki. A casta dos samurais apreciava o teatro Nō e Kyōgen. No teatro $N o \bar{c}$, os dançarinos e atores usam máscaras e o seu propósito artístico é apresentar a beleza solene. Aparentemente o Nō foi inflluenciado pelo Budismo, o que atraiu os samurais, que encaravam a morte a todo instante. Em contrapartida o teatro Kyōgen tinha o objetivo de divertir; portanto, eram cômicos. Tanto Nō como Kyōgen surgiram na segunda metade do século XV. À parte, a corte possuía a sua música sempre homofônica e monódica (não obstante os desencontros resultantes das atuações diferenciadas e com os timbres próprios de cada instrumento), denominada Gagaku (composta por instrumentos típicos, percussão e flautas), dança e parte vocal.

O teatro Kabuki e Ningyō Jōruri (teatro de bonecos) - mais realistas e dramáticos em relação ao teatro $N \bar{o}$, calmo e religioso - tornaram-se os mais populares entretenimentos entre os agricultores e os comerciantes. Podemos considerá-los como a ópera tradicional japonesa encenada no palco. Além do mais, as canções folclóricas, difundidas nessas castas e rejeitadas pelas castas dos samurais e dos intelectuais, que as consideravam vulgares, eram muito mais ricas em termos de melodia, vitalidade e energia refletindo, principalmente o regionalismo de cada canção. A música vocal japonesa consiste, portanto, de muitos tipos distintos. Porém, em geral, têm similaridades em termos de ritmo e melodia, sendo compostas por cinco escalas pentatônicas. Os exemplos a seguir mostram as escalas básicas utilizadas na música tradicional japonesa, segundo estudo de Ichiro Nakano (NAKANO, 1983, p. 244-266). 


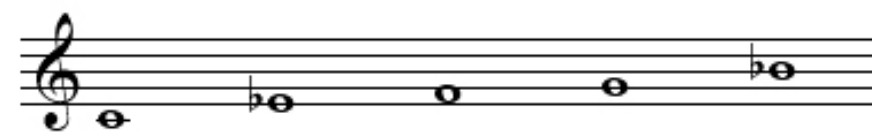

Figura 21: Escala da Canção folclórica (“castas inferiores”).

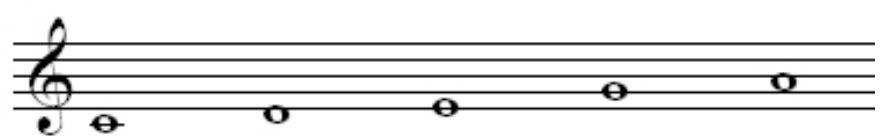

Figura 22: Escala Ryō do Gagaku ("música da corte”).

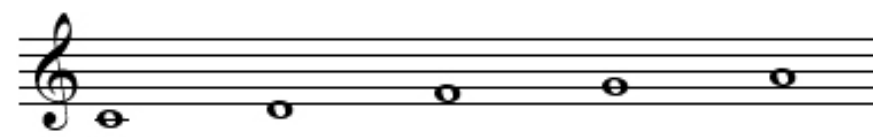

Figura 23: Escala Ritsu do Gagaku ("música da corte").

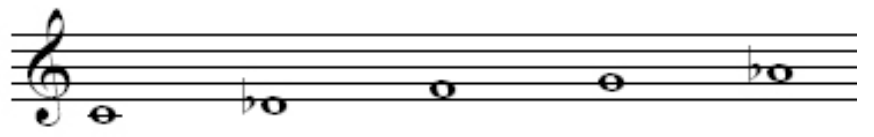

Figura 24: Escala do Miyako-bushi ("samurai urbano" e esse é o caso do famoso Sakura, Sakura).

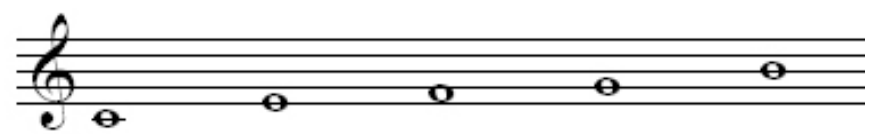

Figura 25: Escala de Okinawa (“uma província ao sul do Japão - regional”).

A linha melódica, entretanto, não pode ser dividida matematicamente em compassos iguais. A melodia é, geralmente, entoada melismaticamente, e seus intervalos são sutis e delicados. Originalmente, a música tradicional japonesa 
era baseada em ritmo livre para que a melodia pudesse ser facilmente prolongada ou encurtada a qualquer instante.

Como já mencionado, um dos aspectos da música tradicional japonesa é o predomínio da música vocal, que pode ser divida em duas tradições: utaimono e katarimono. A melodia é considerada mais importante do que o texto em utaimono; por outro lado, em katarimono, a melodia é subordinada ao significado e à formalidade das palavras.

A mais notável diferença entre as duas tradições é que utaimono é geralmente melismático e katarimono, silábico. Alguns estilos têm separadas as partes de utaimono e katarimono. Essas misturas das duas tradições devem-se ao fato de que a maior parte da música vocal desenvolveu-se com o drama e a dança e requer acompanhamento musical para ser explicativo em algumas partes e lírico em outras.

\subsection{Cinco Canções Japonesas de Rodolfo Coelho de Souza}

A Cinco Canções Japonesas foi composta originalmente para soprano e duas harpas, em 1986, em português e japonês, por Rodolfo Coelho de Souza. Aqui será analisada somente a sua composição em português. A dificuldade em executar a obra com as duas harpas (pela falta de harpistas), fez com que o autor, posteriormente, fizesse uma versão para soprano, piano e marimba, e depois ainda, para soprano, harpa e marimba. O anexo da partitura que consta no final do trabalho é essa última versão (Anexo 4). A estréia, na versão original, ocorreu no XXII Festival Música Nova, no Teatro Municipal de Santos, no mesmo ano em que foi criada a obra.

Segundo relato pessoal, naquele momento o compositor interessava-se pela cultura japonesa. No entanto, sua predileção pelas escalas pentatônicas pode ser vista também como uma decorrência das tendências plurais da música do século $X X$ e do ambiente pós-moderno. A consonância do gosto, das influências e dos estilos resultou na criação dessas obras, que foram compostas inspiradas em cinco tanka (poema japonês composto por 31 
sílabas, distribuídas ritmicamente da seguinte forma: 5 - 7 - 5 - 7 - 7) do poeta Takuboku Ishikawa (1886-1912). Filho de um religioso budista, Ishikawa, levou uma vida amargurada pela tuberculose, dificuldades econômicas, confusões amorosas e familiares nos seus 27 anos, mas tornou-se um dos mais lembrados tankaístas do Japão. A tradução dos poemas foi elaborada por Masuo Yamaki e Paulo Molina. Naturalmente, ao compor em língua portuguesa, a estrutura rítmica da prosódia nipônica baseada na distribuição supramencionada teve que ser desconsiderada, como já o fôra pelo tradutor dos poemas. Entretanto, a característica do tanka de criar atmosferas e imagens em cada uma das cinco unidades, foi mantida nas canções. Serão analisadas somente as duas primeiras canções, visto que o compositor foi distanciando-se cada vez mais das referências das escalas japonesas ao longo das outras canções.

A Cinco Canções Japonesas, de Rodolfo Coelho de Souza, está embasada em tanka que, literalmente significa "poema curto" (tan - curto, breve; e ka - poema ou música), é formada por 31 sílabas (versos de 5 - 7 - 5 7 - 7 sílabas, respectivamente). Sua origem está no waka, termo genérico para designar a poesia aristocrática (também de 31 sílabas). O haiku, mais conhecido e difundido no ocidente, é a forma de 17 sílabas (versos de 5 - 7 - 5 sílabas).

A mais antiga coletânea dessa modalidade de poesia do Japão foi compilada no século VIII (743-759). Trata-se da Manyōshū, coletânea composta de 4.516 poemas divididos em 20 volumes, escritos por mais de 400 praticantes, do imperador ao simples camponês. A família imperial realiza, ainda hoje, no início do ano, uma reunião cerimoniosa em que o imperador, a imperatriz, os príncipes e as princesas apresentam seus tankas. Chama-se Shin-nen-uta gyotai ou uta gyokai - hajime.

Para ilustrar a importância do tanka na história do Japão, lembremos que o Hino Nacional, o Kimigayo, é um poema tanka: Kimiga yo wa (5)/ chiyoni tachiyoni (7)/ sazareishino (5)/ iwa o to narite (7)/ koke no musumade (7). A versão do Consulado Geral do Japão $\left(^{*}\right)$ é a seguinte: "Que sejam vossos dez 
mil anos de reinado feliz / governai, meu senhor, até que os que agora são seixos / transformem-se, unidos pelas idades, em rochedos poderosos / cujos lanços veneráveis o musgo cobre".

O tanka tem mudado ao longo do tempo, mas a sua forma silábica, contendo cinco unidades - cada linha consistindo de uma imagem ou idéia com 31 sílabas, continua a mesma. Os tópicos se expandiram da forma tradicional de expressões de paixão e dores do coração para incluir a linguagem moderna e até mesmo coloquialismos. Inclusive, o tanka também tem sido composto em outras línguas.

A Cinco Canções Japonesas de Rodolfo Coelho de Souza são:
1) Nas mãos
2) Fumaça
3) Há dias
4) O longo corredor
5) Quando acendi

\section{Canção 1:}

Nas mãos

Um punhado de areia

Lágrimas

A escorrer pelas faces

Como te esquecer

\section{Canção 4:}

O longo corredor

Do hospital

E o desejo de ir

Uma vez

Até o fim

\section{Canção 2:}

Fumaça que se desfaz

No céu azul

Fumaça que se desfaz

Melancolicamente

Meu espelho

\section{Canção 5:}

Quando acendi

O fósforo

Uma mariposa branca

Atravessou

A sombra da mão

\section{Canção 3:}

Há dias

Em que penso

Ser minha linguagem

Talvez

A do vento 


\section{A) Análise da Canção 1:}

Verificam-se dois conjuntos pentatônicos nesta obra:

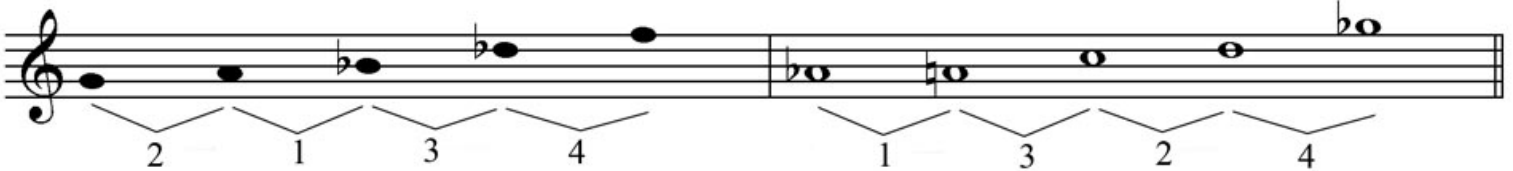

Figura 26: Conjunto Pentatônico 1.1 e Conjunto Pentatônico 1.2.

Os intervalos entre as notas são os mesmos nos dois conjuntos em sequências diferentes, como podemos verificar na Figura 27. Ao ordenarmos aproximando as notas dos extremos, sem alterar a sequência das notas, transpondo a primeira nota para a nota Dó, os dois conjuntos assemelham-se à escala pentatônica Ryo do Gagaku (Figura 28). O conjunto 1.1 tem as notas Dó, Mi e Lá, comuns a essa escala nipônica e o conjunto 1.2 tem somente duas notas, Dó e Ré; porém, quase todos os intervalos entre elas, na sequência, são proporcionais à escala, o que produz semelhança sonora.

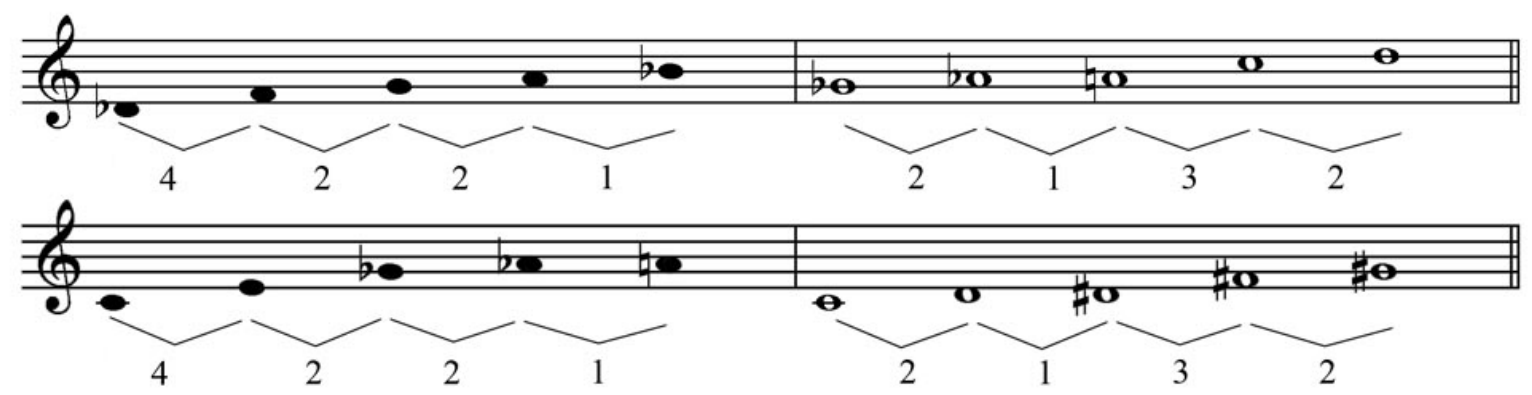

Figura 27: Os conjuntos pentatônicos transpostos.

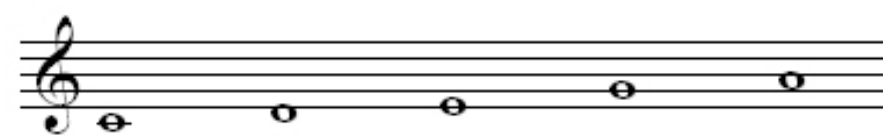

Figura 28: Escala Ryō do Gagaku (“música da corte”) - [2,2,3,2]. 
A nota Lá é comum aos dois conjuntos, estando inserida em todos os compassos da peça, tal como podemos verificar na Figura 29. No início da obra prevalece o primeiro conjunto pentatônico (notas pretas), que aos poucos vai se intercalando com as notas do segundo conjunto (notas brancas). As notas Mi e Mi $b$ - circundadas não pertencem a nenhum dos conjuntos. Em 4/4, a peça totaliza 13 compassos.

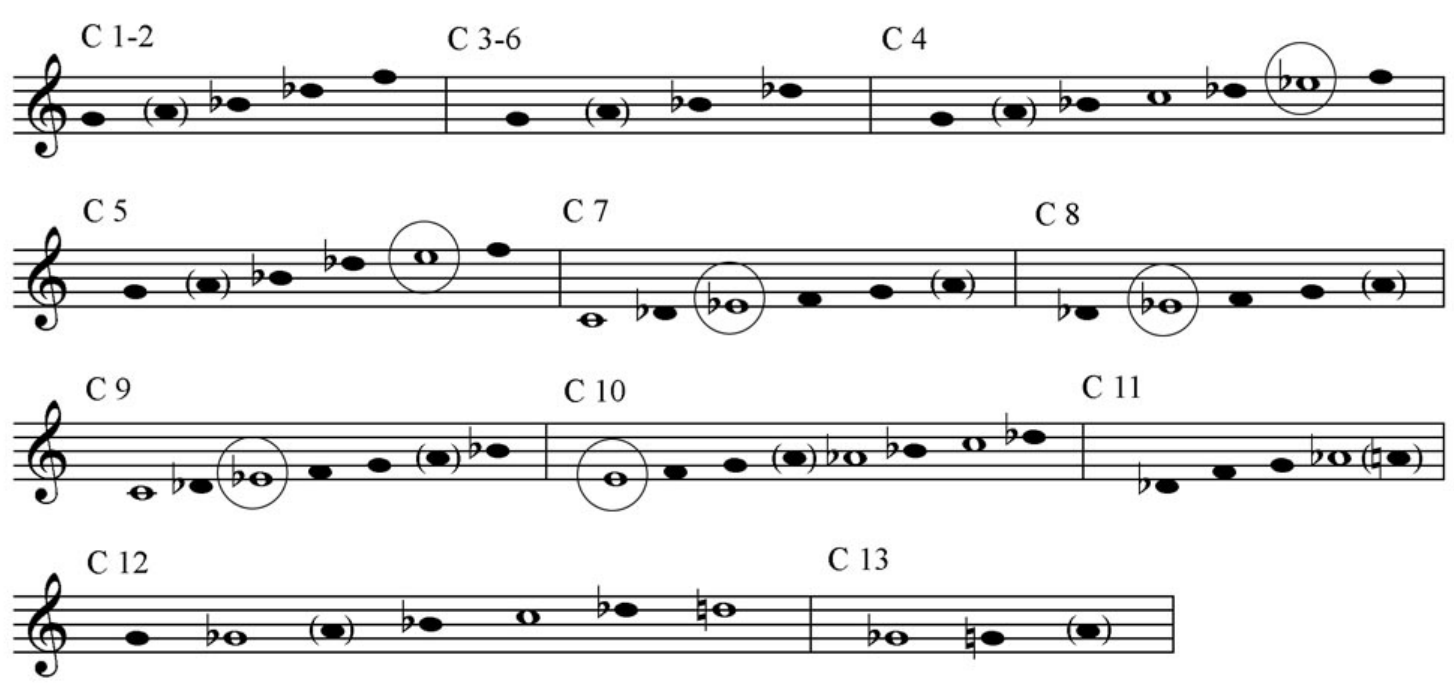

Figura 29: Notas musicais de todos os compassos da primeira canção de Cinco Canções Japonesas (Rodolfo Coelho de Souza).

A linha melódica da peça distribui-se em cinco unidades, tal qual a estrutura do tanka. As quatro primeiras unidades pertencem ao Conjunto Pentatônico 1.1 e a última unidade ao Conjunto Pentatônico 1.2 (Figuras 30 e 31). 
1

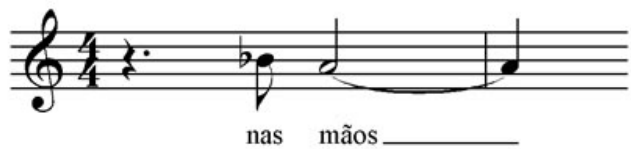

Conjunto Pentatônico 1.1

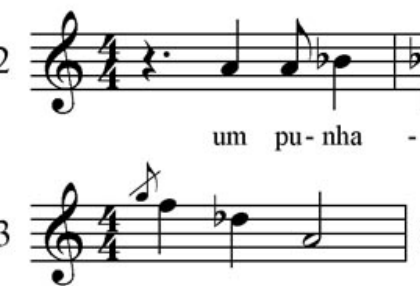

Conjunto Pentatônico 1.1

lá - gri - mas

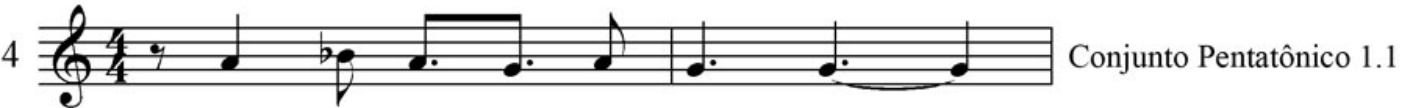

aes - cor - rer pe - las fa - ces

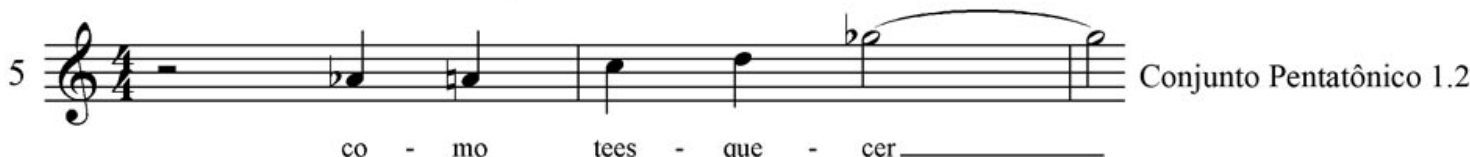

Figura 30: Unidades melódicas da primeira canção de Cinco Canções Japonesas (Rodolfo Coelho de Souza).

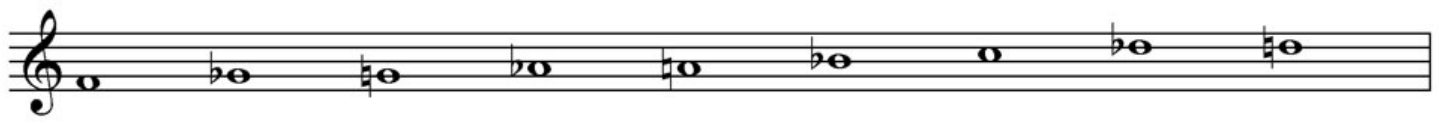

Figura 31: Os dois conjuntos pentatônicos da melodia da primeira canção de Cinco Canções Japonesas (Rodolfo Coelho de Souza).

Ocorre aqui uma fusão das notas da melodia e formam a sequência de uma série cromática.

\section{B) Análise da Canção 2:}

Verificam-se também nesta segunda canção dois conjuntos pentatônicos. 


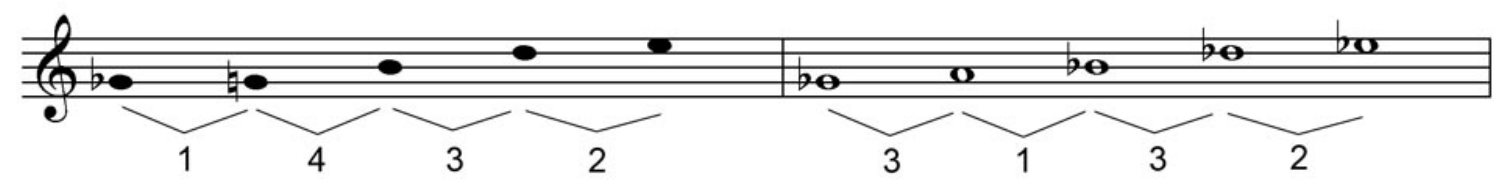

Figura 32: Conjunto Pentatônico 2.1 e Conjunto Pentatônico 2.2 da segunda canção de Cinco Canções Japonesas (Rodolfo Coelho de Souza).

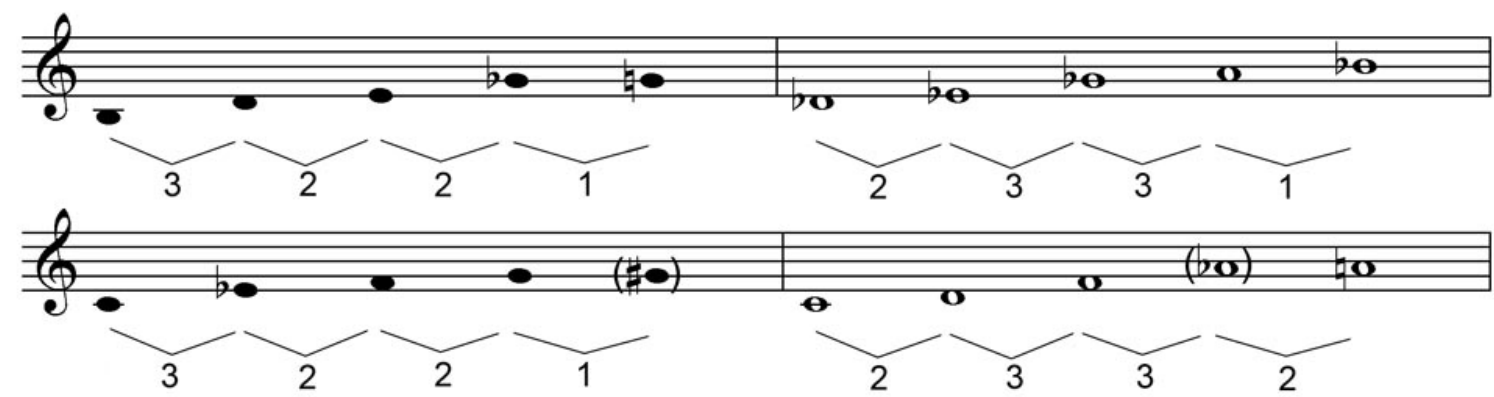

Figura 33: Os conjuntos pentatônicos transpostos.
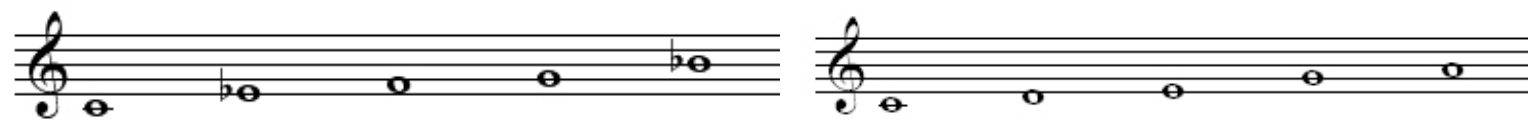

Figura 34: Escala da Canção folclórica ("castas inferiores") - [3,2,2,3] e Escala Ryō do Gagaku ("música da corte") - [2,2,3,2].

Essa segunda canção possui a mesma estrutura da primeira, ou seja, uma construção também em dois conjuntos pentatônicos que vão se combinando no decorrer da peça. Nessa, o primeiro conjunto vai sendo substituído pelo segundo conjunto (Figura 35). A nota comum é o Sol $b$, presente em todos os compassos, com exceção dos compassos 19 e 20. Em $3 / 4$, a peça totaliza 21 compassos.

O procedimento para análise é o mesmo da canção 1 , ou seja, a aproximação mais condensada das notas dos extremos e depois a transposição da primeira nota à nota Dó. O Conjunto Pentatônico 2.1 tem características muito próximas à escala da canção folclórica ("castas 
inferiores"), tendo em comum todas as quatro primeiras notas na mesma ordem. Não obstante o próprio compositor não ter se deparado com esses fatos, o Conjunto Pentatônico 2.2 aproxima-se também, da mesma forma, à Escala Ryō do Gagaku (“música da corte”), ou seja, há quatro notas em comum. No entanto, a nota que difere é a quarta nota, Lá b. Assim, nessa canção verificam-se dois conjuntos pentatônicos onde o primeiro, identificado como semelhante às escalas pertencentes à casta inferior, e que vai sendo substituído pelo segundo conjunto, pertencente à corte.

C $1-71318$

C $2-4-5$

C $3-14$
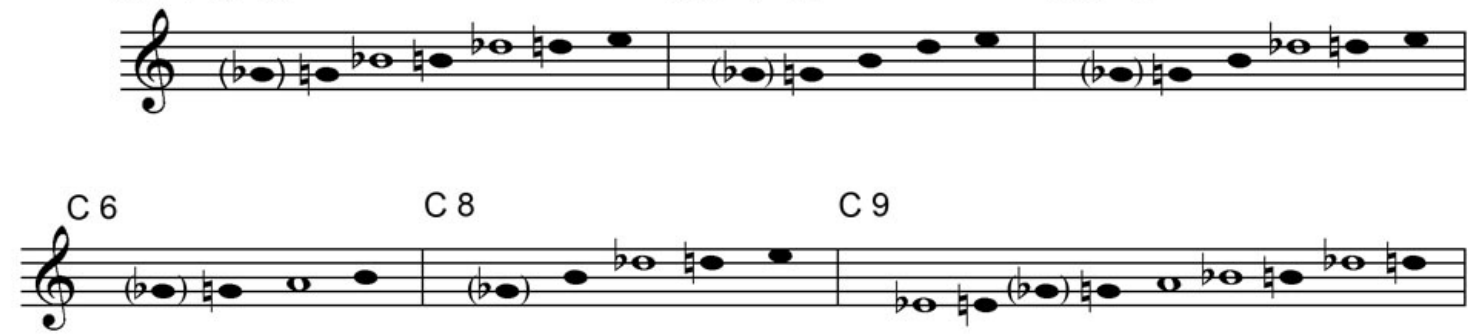
C 10
C 11

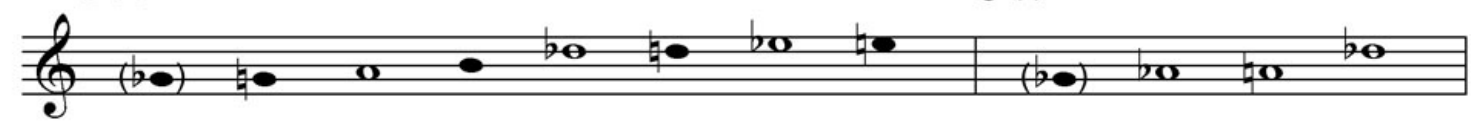

C 12

C $15-16-17$

C 19

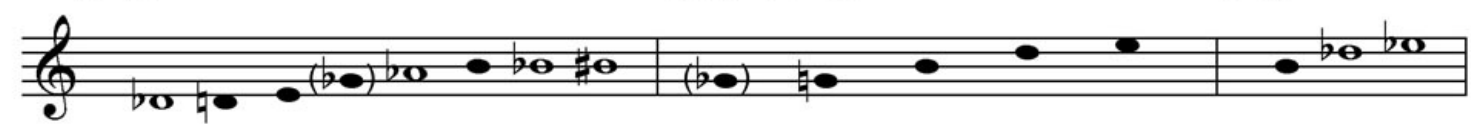

C 20

C 21

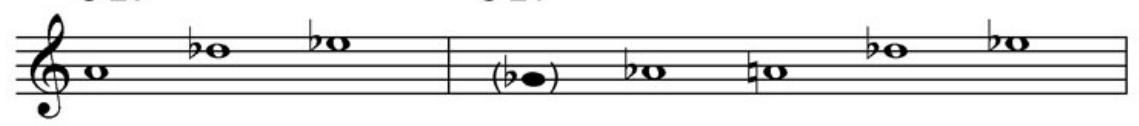

Figura 35: As notas musicais de todos os compassos da segunda canção de Cinco Canções Japonesas (Rodolfo Coelho de Souza).

Como a primeira canção, a segunda também é dividida em cinco unidades, e as quatro primeiras pertencem ao Conjunto Pentatônico 2.1 e a 
última ao Conjunto Pentatônico 2.2 (Figura 36). As notas da melodia de todas as canções seguem uma sequência cromática (Figuras 37 e 38).

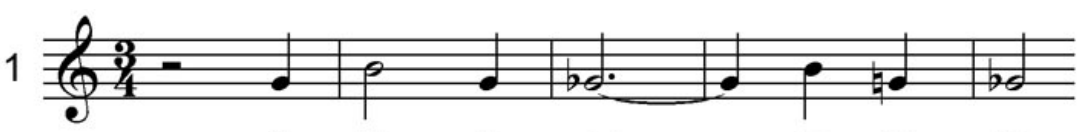

Conjunto Pentatônico 2.1

$\mathrm{fu}$ - ma - ça que

se des - faz

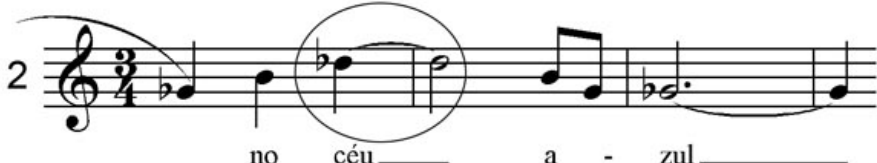

Conjunto Pentatonico 2.1

no

a

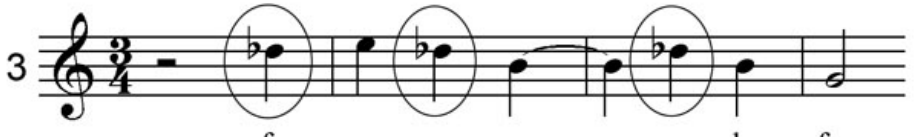

Conjunto Pentatônico 2.1

fu - ma - ça

que

se des - faz

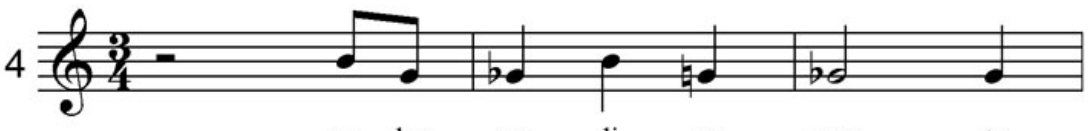

Conjunto Pentatônico 2.1

me - lan - co - li - ca - men - te

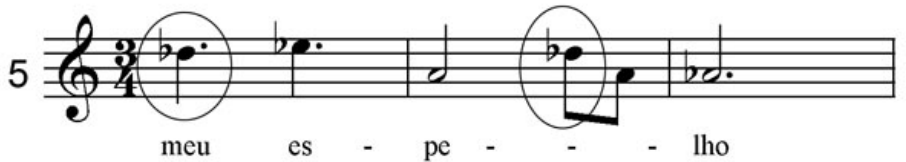

Conjunto Pentatônico 2.2

Figura 36: Unidades melódicas da segunda canção de Cinco Canções Japonesas (Rodolfo Coelho de Souza). Obs: a nota Ré $b$, circundada, não pertence a nenhum dos conjuntos.

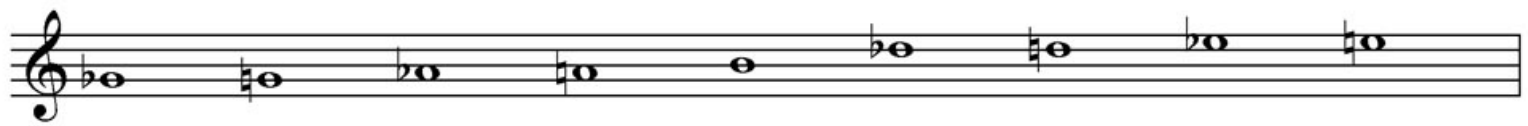

Figura 37: As notas da linha melódica da mesma canção, ordenadas da nota mais grave para a mais aguda seguindo uma sequência cromática como fusão dos dois conjuntos pentatônicos. 


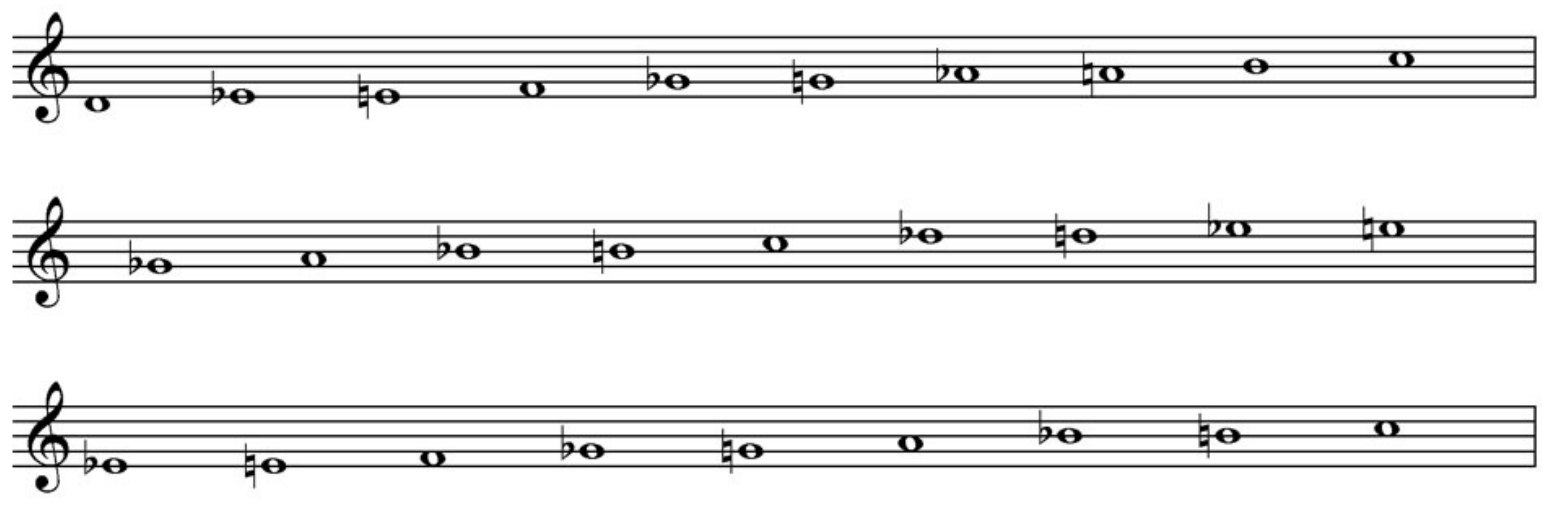

Figura 38: Linha melódica da canção 3, 4 e 5 de Cinco Canções Japonesas (Rodolfo Coelho de Souza) que, se ordenadas, formam a série cromática.

Considerando as transformações da sociedade japonesa e brasileira como construção política e o movimento da pós-modernidade no âmbito global, a obra de arte adquire um contorno multifacetado de linguagens - cromatismo, pentatonismo, minimalismo, tonalismo ou atonalismo - como na Cinco Canções Japonesas de Rodolfo Coelho de Souza. Como poderíamos defini-las, ou nomeá-las como sendo japonesas? Seus conjuntos pentatônicos? O poema tanka? O que importa? É a sua visão, seu paladar, sua sonoridade adquirida da poética nipônica. Nas palavras de Ricoeur:

(...) toda visão é um ponto de vista. O mundo é um horizonte de todo objeto, que só é percebido em parte. Há possibilidades infinitas de captá-lo. Muitos pontos de vista nos escapam. No entanto, podemos dizê-los: pela linguagem, falamos das fisionomias ocultas e não percebidas das coisas. Falamos delas em sua ausência (RICOEUR, 1990, p.3).

Apesar dos conjuntos pentatônicos encontrados na Cinco Canções Japonesas não serem exatamente os mesmos utilizados na música vocal tradicional japonesa, o percurso de Rodolfo Coelho de Souza em busca de sua linguagem musical próprio é análogo ao de outros compositores. São vários os compositores que buscaram inspiração no "não-ocidental" diante de um esgotamento estético de fin-de-siècle europeu. Claude Debussy (1862-1918) utilizou-se de conjuntos pentatônicos após entrar em contato com a música 
Gamelan de Java, em 1889, em Paris. Debussy teve o intuito de, talvez, dar a impressão de "exotismo" em sua sonoridade. Béla Bartók (1881-1945), desejando superar (num processo dialético de Aufhebung ${ }^{27}$ ) os dois modos da tonalidade (maior e menor), encontra nas escalas pentatônicas das melodias (neo) folclóricas uma nova forma de empregar combinações rítmicas, cromatismos e tonalidades sem hierarquias.

Essa segunda fase composicional de Rodolfo Coelho de Souza - a minimalista - está à procura de uma não tensão propiciada pela atmosfera contemplativa oriental. Isso cria um ambiente favorável para o tanka que proporciona, por sua vez, imaginários de cores, paisagens e estados d'alma em unidades sutis. Todavia, com todo o aspecto engenhoso dessa obra, o autor expressa assim, o sentimento recôndito nela.

\footnotetext{
${ }^{27}$ No Dicionário Básico de Filosofia de Danilo Marcondes e Hilton Japiassú encontramos a seguinte definição para Aufhebung: (al. aufheben: conservar e suprimir) Hegel utiliza esse termo, jogando com sua ambigüidade, para designar, no movimento dialético, a passagem de um estado a outro. Todo novo estado nasce da negação do estado precedente: visa aboli-lo, mas, de certa forma, conservá-lo. Assim, designa a ação de ultrapassar uma contradição. "Aufheben tem um duplo sentido: significa guardar, conservar e, ao mesmo tempo, fazer cessar, pôr fim a. A idéia de conservar já contém nela mesma esse elemento negativo consistindo em que, para guardá-lo, algo é subtraído a um ser imediato" (Hegel).
} 
CAPÍTULO 5: Flores 


\subsection{Cerejeiras e ipês}

Haveria algum povo que não tenha se inspirado nas flores para cantar? Não há povo que não canta e não deve haver um povo que não se encante com as flores. A não ser onde não haja flores, o que deve ser muito triste. Isso não acontece no Brasil. E muito menos no Japão, onde a natureza exerce influências intensas no cotidiano, na filosofia, nas religiões e em toda arte japonesa, como brevemente descrita no Capítulo 3.

Não é por acaso que Zeami Motokiyo (1364-1444), que consolidou o teatro $N o ̄$ (o mais significativo empreendimento cultural do Japão na Idade Média, que durou até 1854), estabeleceu em seu primeiro tratado Fūshikaden (Da Transmissão da Flor de Interpretação), uma temática que é o conhecimento da flor. "A flor representa, de fato, a vida do Nō e conhecê-la significa atingir os arcanos do caminho desta arte" (GIROUX, 1991, p.106 apud "Fūshikaden: De la transmission de la fleur de l'interpretation", por R. Sieffert, op. cit, p. 84).

Em linguagem teatral seria o efeito cênico da representação de Nō ou o impacto emocional provocado pelo trabalho do ator. Essa flor do palco é captada em primeira instância pelo espectador. A flor é a imagem do belo que suscita o sentimento do espectador através da linguagem de representação. Por outro lado, ela difere da simples flor da natureza na medida em que esse belo refletido nos olhos do espectador deve coincidir com aquele que é concebido subjetivamente pelo ator. A concepção segundo a qual "a flor se encontra na disposição do espírito; a semente deve ser o ofício" ou a idéia de que a flor nasce da técnica que suscita o sentimento imprevisível na alma humana, supõem que a flor se manifesta a partir do ator. Assim, o belo da flor que se reflete nos olhos do público e a alma da flor que nasce do sentimento do ator, formam o verso e o reverso de uma mesma flor, que se misturam sutilmente, refletindo a complexidade desse termo. 
Zeami uniu a experiência artística à reflexão estética. O termo yūgen, empregado para expressar idéias encontradas no Taoísmo e no Budismo, significava "ser tão indistinto e profundamente misterioso a ponto de estar além da percepção e compreensão humana". Tsubaki (1971) encontra, após inúmeros conceitos, uma definição contemporânea em Zeami. Ele atinge o conceito de "the beauty of gentle gracefullness" como princípio estético do teatro Nō.

A imagem da flor na cultura japonesa é de graça, fineza, beleza pura; no entanto seu cunho de significação profunda é a existencialista, principalmente quando se trata do sakura (flor de cerejeira). A ária anônima composta por volta de 1885 (que se questiona quanto a sua origem: os japoneses dizem que é japonês, mas os chineses estão dizendo que é chinês), sakura, sakura é quase um hino no Japão. É um dos ícones representativos da cultura japonesa. Seus versos são assim traduzidos:

\footnotetext{
As flores de cerejeira

Branda como brumas

Estendendo-se por toda a paisagem

Sob o céu brilhante de março.

Vamos apreciar as graciosas flores
}

Elas florescem todas ao mesmo tempo. De cores claras, encobrem a cerejeira sem folhas e invadem montanhas, parques e cidades. Duram somente alguns dias e caem todas como uma chuva de flores ao sussurrar de um vento. Apreciar as flores de cerejeiras é quase um ritual. Consiste num sentir em como a vida é bela, mas breve, e constatar a imutável transitoriedade da existência humana.

Acostumados a esse ritual de beleza das flores da terra natal, um imigrante japonês encontra nas flores do ipê algo que lembra suas cerejeiras em flor. Sem folhas, as flores do ipê florescem também todas ao mesmo tempo, causando deslumbre aos olhos de quem o contempla.

Charles Rosen acrescenta que o que confere à paisagem a dignidade da poesia épica e da pintura religiosa e histórica não são as evocações das 
belezas e delícias dos hábitos pastorais, nem o virtuosismo da imitação dos objetos da natureza pelos artistas, mas a co-relação entre a experiência sensível da natureza e as obras intelectuais e espirituais da mente (ROSEN, 2000, p. 194-195).

Ainda Gadamer no seu texto intitulado $A$ doutrina do ideal da beleza, referindo-se à representação da natureza, afirma:

A essência de toda arte reside, em si, no fato de que, como Hegel o formulou, "traz o homem para diante de si mesmo" (Vorlesungen über die Ästhetik, ed. Lasson, p. 57: "Por conseguinte, a necessidade geral da obra de arte deve ser procurada no pensamento do homem, já que é um modo de colocar diante do homem o que este é"). Também outros objetos da natureza - não somente a figura humana - podem expressar, na representação artística, seja de uma paisagem, seja de uma natureza morta, até mesmo a embevecida observação da natureza, causa esse efeito... sua tarefa - a da arte - não é mais a representação do ideal da natureza - mas o auto-encontro do homem na natureza e no mundo humano-histórico (GADAMER, 2002, p. 101102).

Em se tratando agora da representação da natureza na cultura japonesa, podemos considerar também (além dos descritos no capítulo 3) este trecho a seguir:

(...) Por exemplo: a natureza. Um tema cultivado entre os japoneses, ela sempre surgia como algo espiritualizado, sendo tradicionalmente descrita em seus traços monumentais: "bela", "artística", "magnânima", "opulenta" etc. Traços que se fundem a um outro, furusato (terra natal), lugar idealizado no qual repousariam as autênticas raízes da japonidade. Aí a nostalgia urbana encontraria a "verdadeira" origem dos que dela se distanciaram. A natureza, "bela", "envolvente", emanação imaculada da espiritualidade "oriental", e a "terra natal", perdida nos confins de algum vale oculto, têm assim uma função mítico-ideológica celebrando a presença de um passado ausente (Robertson apud ORTIZ, 2000, p. 125).

É assim que cerejeiras e ipês se cruzam para dialogar com o que se encontra oculto, além das aparências florais. Depois que caem as flores é a chegada simbólica do outono existencial, prenunciando o inverno. Ou quando o sol se põe, deixa lugar para uma noite misteriosa e escura. A transição entre a luz e as trevas, entre a vida e a morte. A sensação profunda e dolorosa do 
passar inevitável do tempo. A consciência da fragilidade de nossas vidas, fluindo continuamente sem que possamos detê-la, sem que possamos nos apropriar dela, ainda que por um único instante.

\subsection{Acalanto para Noemi de José Antonio de Almeida Prado}

O sentimento primaveril que sensibiliza a alma é, portanto, ontológico. Tanto o desabrochar das flores de cerejeiras assim como o desabrochar das flores de ipês impulsionam a inspiração para o canto. Almeida Prado mergulha nesse estado d'alma exaltando a beleza de um florescimento. Podemos considerar que essa canção é dotada de um sentido "profundo" com o de "beleza charmosa" tal como o yūgen, a técnica de expressão do teatro Nō acima citado.

José Antonio de Almeida Prado compõe, em 1996, Acalanto para Noemi, para canto e piano. Nascido em Santos, em 8 de fevereiro de 1943 é considerado um dos principais expoentes da música brasileira, foi aluno de Camargo Guarnieri e Osvaldo Lacerda no Brasil, e de Olivier Messiaen e Nadia Boulanger, na França. Um dos primeiros compositores brasileiros de "música de vanguarda", Almeida Prado não se limitou às inovações à Darmstadt. Desenvolvendo sua própria linguagem utilizou com maestria, desde o modalismo até o atonalismo pós-serial, somando-se as técnicas de Olivier Messiaen (cuja obra é sempre referencial para Almeida Prado) e outros compositores franceses.

\footnotetext{
Hoje em dia, o compositor afirma ter alcançado um alto grau de "liberdade estética", não se prendendo a estilos e misturando diferentes técnicas e estéticas como Ihe convém. Todas estas características podem ser observadas em algumas de suas obras mais importantes como os Pequenos Funerais Cantantes, a Missa de São Nicolau e, principalmente, as Cartas Celestes, um ciclo de 14 peças para piano compostas durante vários períodos de sua carreira. (BITONDI,s.d.)
}

Assim, após ter composto mais de 400 obras que incluem desde formações camerísticas e solistas até grandes formações sinfônicas, essa obra 
tão singela é elaborada na concepção imagética da sonoridade nipônica que possui o compositor. E cita na própria partitura que modos pentatônicos utilizou e de onde os retirou.

Vejamos o que escreve Persichetti sobre escalas pentatônicas: "há vários tipos de escalas básicas de cinco tons ou pentatônicas. Algumas das mais conhecidas são: Escalas Diatônica, Pelog, Hirajoshi e Kumoi (Figura 39).
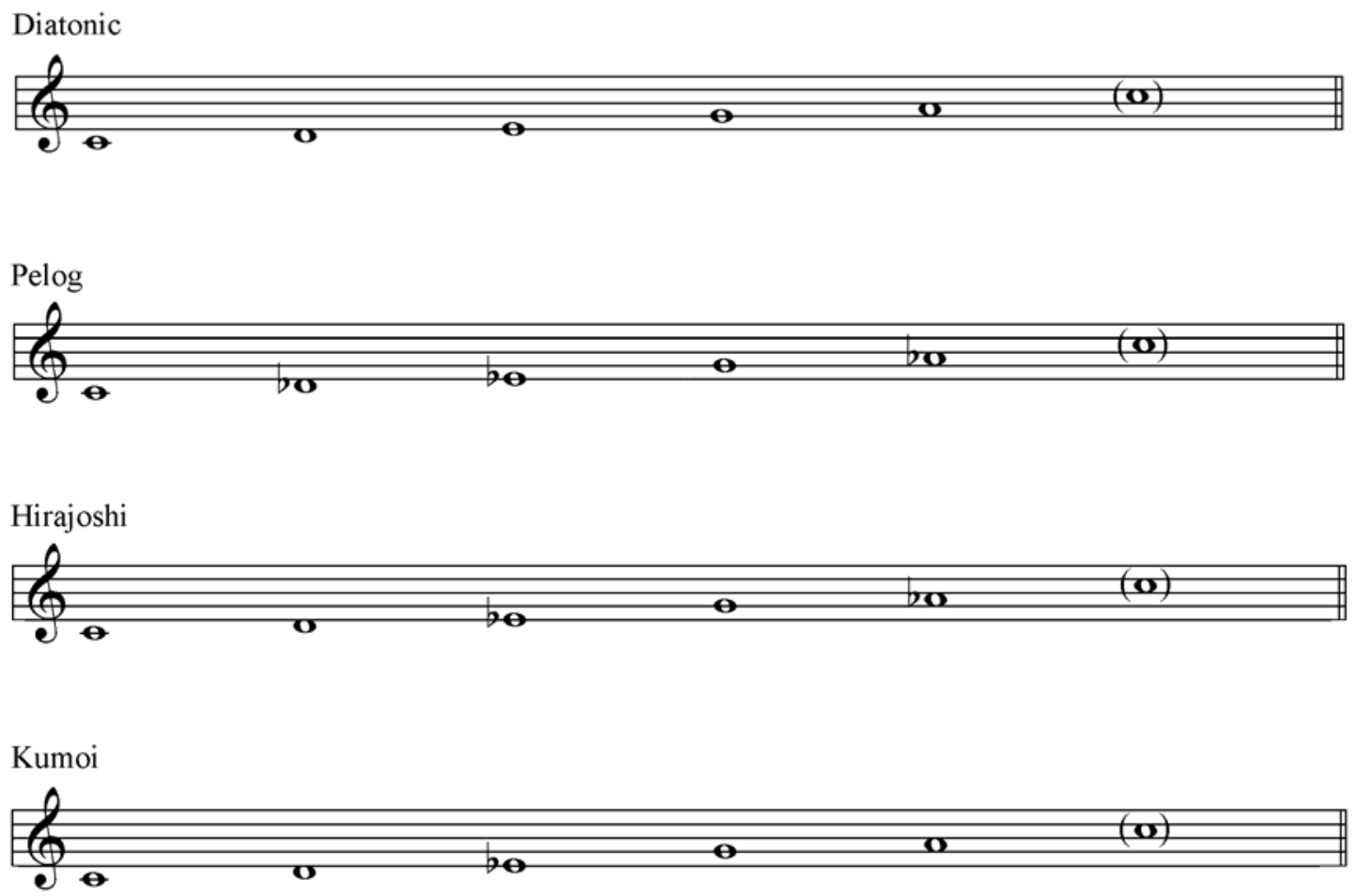

Figura 39: Escalas pentatônicas Diatônica, Pelog, Hirajoshi e Kumoi.

A técnica da construção modal que produz sete modos diatônicos produz cinco modos de cada tipo da escala pentatônica (PERSICHETTI, 1961, p. 50). Assim, as cinco formas modais do pentatônico diatônico são os seguintes: 


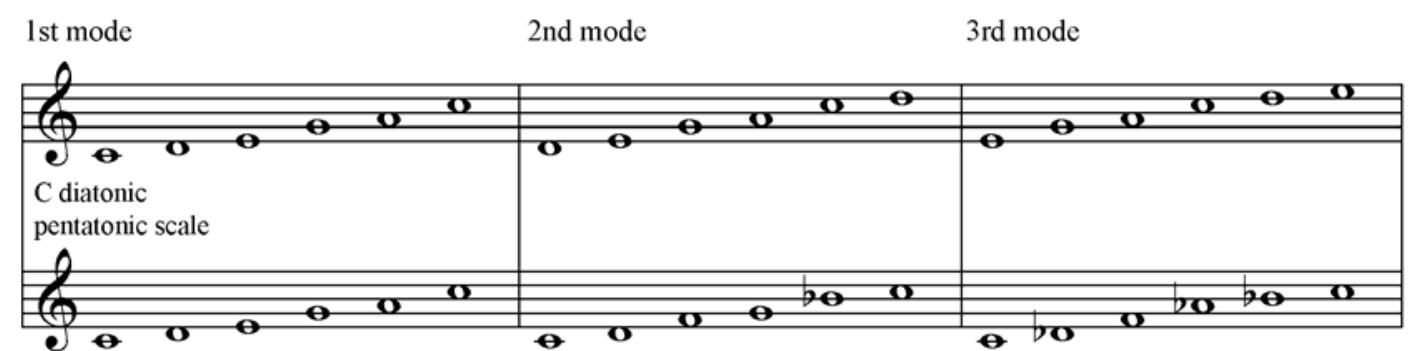

4th mode 5 th mode

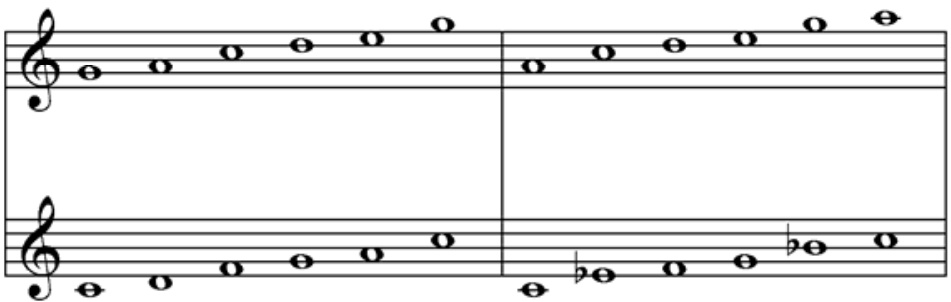

Figura 40: Cinco formas modais do pentatônico diatônico transpostas para a mesma tônica para comparação.

As escalas diatônicas de cinco tons são harmonicamente limitadas em termos de liberdade de ação em virtude da falta de semitons (quando todos os cinco tons da escala pentatônica soam juntos eles formam um acorde um tanto estático). Portanto, é extremamente difícil alcançar direção harmônica e melódica na forma pentatônica pura.

Quando melodia e harmonia são pentatônicas, mudando a versão modal do pentatônico ou movendo de um pentatônico para o outro ajudará a prevenir a monotonia. Usos generosos de tons ornamentais, pontos de pedal, alternâncias modais frequentes ou modulações pentatônicas ajudarão também a prevenir monotonia harmônica; mas a música pentatônica pura (não polimodal, etc.) é mais efetiva quando utilizada em breve espaços de tempo. Materiais pentatônicos funcionam bem melodicamente ou harmonicamente, mas raramente ambos. Melodias pentatônicas são frequentemente harmonizadas com acordes fora da escala pentatônica. Um tipo de escala pentatônica combina bem com outro tipo na mesma tonalidade ou em diferentes centros tonais. 
Aqui se encontra a forma de criação dessa obra, dedicada ao nascimento da Noemi, filha do casal Adriana e Milton Kayama, cujo poema foi escrito por Kinjiro Yoshihara (1900-1975), avô materno de Milton ou bisavô de Noemi. O poema se encontra em Poemas de Kinjiro Yoshihara, e sua tradução é:

$\begin{array}{ll}\text { Mori no sei } & \text { O espírito da floresta } \\ \text { Sasayaki ipê } & \text { Sussura ao mundo, } \\ \text { Hokorobiru } & \text { E o ipê } \\ & \text { Vai se abrindo }\end{array}$

Almeida Prado compôs em japonês. A canção é elaborada sobre modos e harmonias pentatônicas. Tanto a melodia quanto o acompanhamento pelo piano são pentatônicos. Almeida Prado utilizou o modo Hirajoshi $\left(3^{a}\right.$. transposição) até o compasso 14 e a partir do compasso 15 , modo Kumi (4a . transposição) até o final da canção. Esses procedimentos são informados pelo próprio autor na partitura manuscrita da obra.

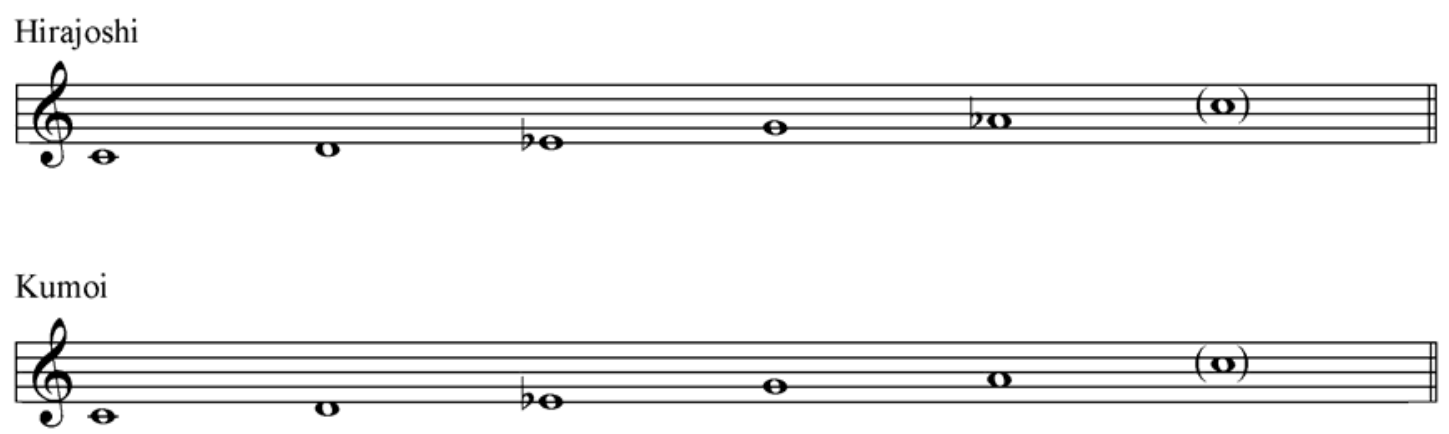

Figura 41: Modos Hirajoshi e Kumoi.

Apesar de não haver nenhum acidente na clave, não há tonalidade definida na obra. As transposições e a mudança do conjunto pentatônico criam certo aspecto de movimento na canção. O pedal é contínuo, gerando, portanto, 
a mistura das cinco notas. A melodia emerge, assim, desse conglomerado de notas do piano. A mão direita e a esquerda sucedem harpegiados em movimento contrário ao longo de toda obra.

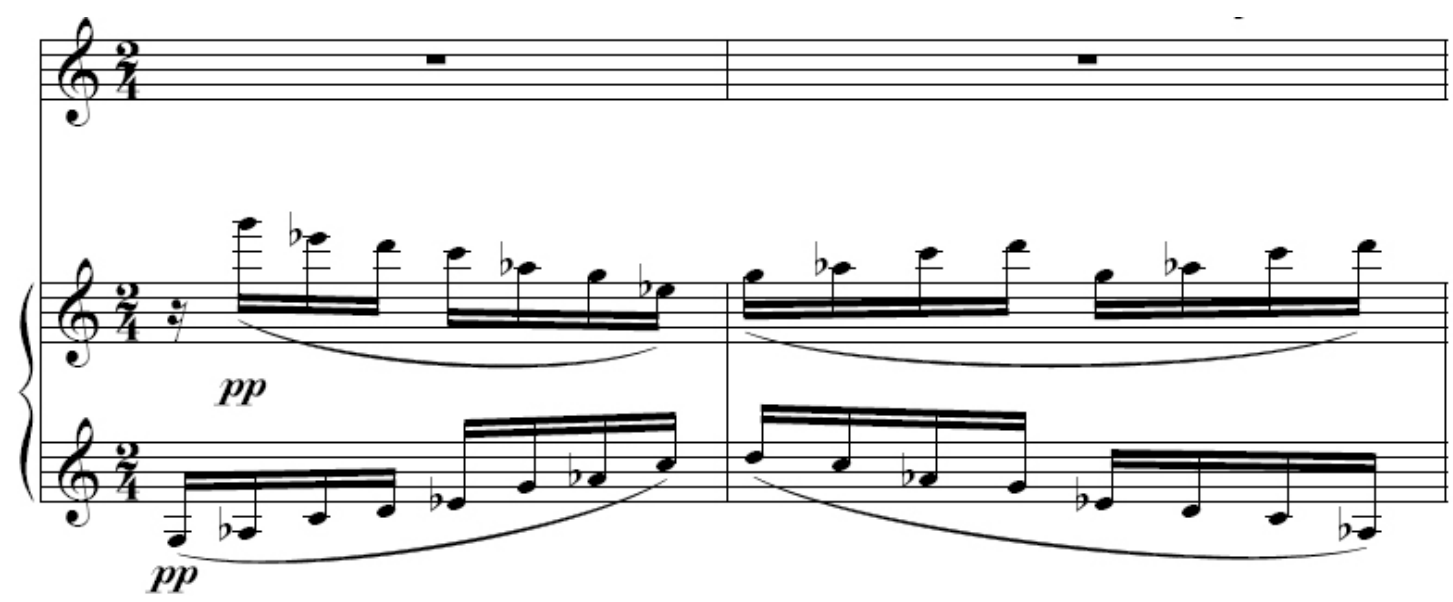

Figura 42: Compassos 1 e 2 de Acalanto para Noemi (Almeida Prado).

O piano em semicolcheias na mão direita e esquerda desliza harpejado sem pausa. Há acordes na mão direita somente nos compassos 28 a 31, na finalização da canção. 

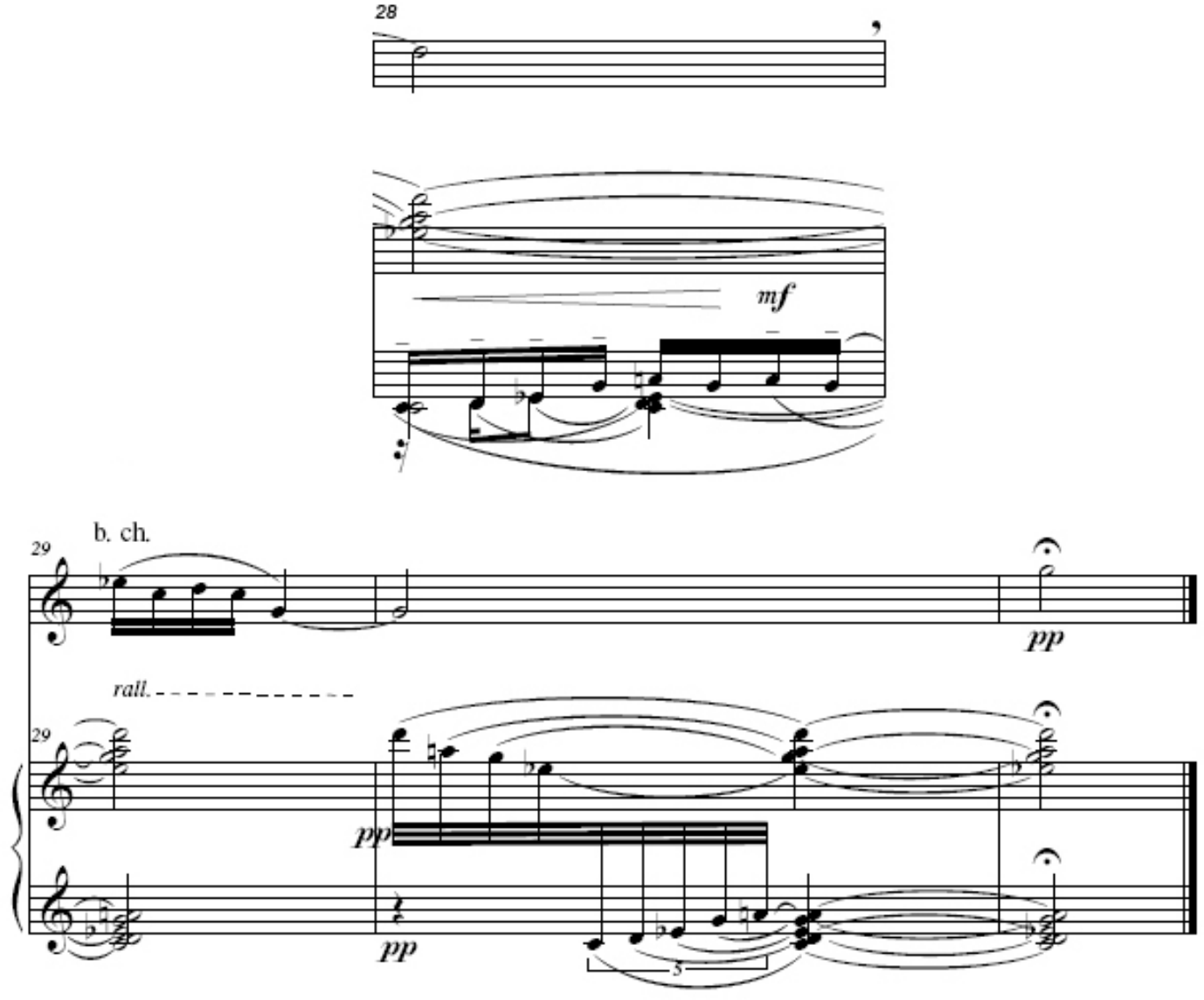

Figura 43: Compassos 28 a 31 de Acalanto para Noemi (Almeida Prado).

Sem acentos fortes na cabeça do tempo, tanto da voz quanto do piano, a canção sugere um movimento horizontal. É bom lembrar que a música tradicional japonesa não é dotada de uma pulsação fixa como na música da Europa. Portanto, essa disposição da voz e do piano induz a esse tipo de sonoridade sem pulsação aparente. Em compasso $2 / 4$ e colcheias $=52$. As semicolcheias predominam a obra, tanto na voz quanto no piano. As pausas de semicolcheias são regulares no início das frases vocais, induzindo o enfraquecimento do tempo forte dos compassos. 

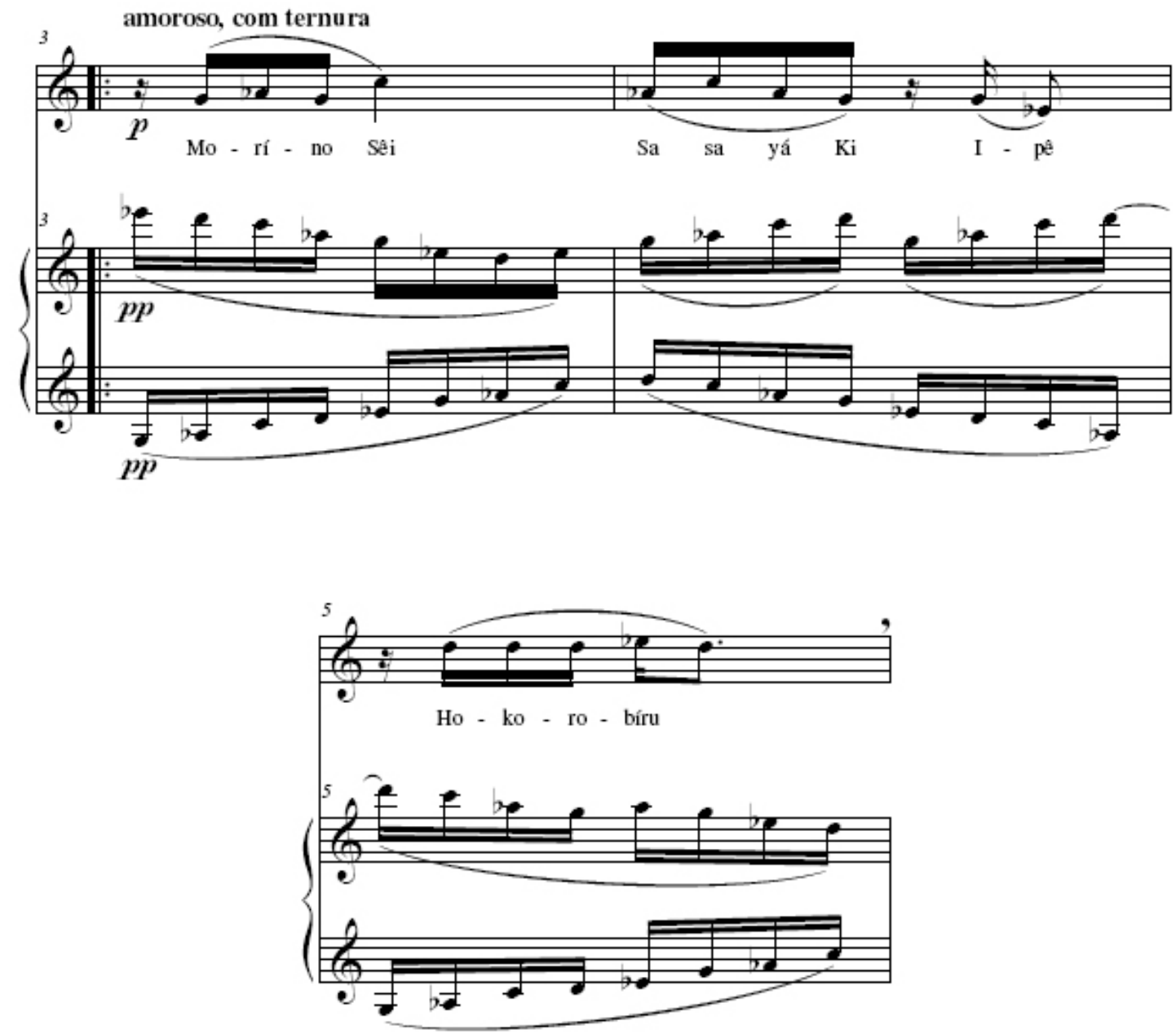

Figura 44: Compassos 3 a 5 de Acalanto para Noemi (Almeida Prado).

Somente a bocca chiusa começa no tempo forte, mas ela por si só é dotada de pouca sonoridade. O "ipê" é sempre coroado pelas pausas de semicolcheias, tanto antes como depois de evocado, como se pode verificar na Figura 44 (acima). Isso se deve para ser, provavelmente, enfatizado como um vislumbre, uma miragem da flor de cerejeira. O autor utiliza-se da bocca chiusa para proporcionar a sonoridade do acalanto, após todas as vezes que termina a evocação do poema. 
O poeta (imigrante japonês) é um narrador ${ }^{28}$ : "O espírito da floresta sussurra ao mundo", sugere uma incerteza em um mundo tropical desconhecido, mas tem uma voz, ainda que sussurrada, com espírito. E do escuro da floresta, o espírito sussurrado vai desabrochando "o ipê" trazendo luz e conforto acalantado. O compositor indica que seja executada amoroso, com ternura.

Com certeza, o poeta vislumbrando a flor do ipê, lembra a flor de cerejeira e o compositor ao ler o poema proporciona uma atmosfera que lembra uma japonidade melancólica, saudosa de sua terra natal. Através da fusão em que mesclam as notas pentatônicas, Almeida Prado deixa reverberando, como que "suspensos no ar", uma sonoridade etérea.

\footnotetext{
${ }^{28}$ Esta análise poética é considerada a partir do poema já traduzido, considerando que difere em certos aspectos do poema original em japonês.
} 


\section{CONSIDERAÇÕES FINAIS: Transcendência}


Há inúmeros aspectos do ato de cantar - retomando a definição de Jacqueline Bonnardot - que são relevantes para uma boa execução musical: o domínio do corpo, do espírito e da sensibildade, o trabalho regular da postura, do sopro, da flexibilidade, do relaxamento do aparelho vocal, da dicção, do enriquecimento da imaginação, do conhecimento musical e dos seus entornos, e saber cantar sem fadiga inúmeros estilos musicais para o deleite do público e de si próprio.

Diz um antigo provérbio japonês que "para saber o ato, é preciso compreender o objeto". Assim, transcrevendo, posso afirmar então que "para saber o canto, é preciso compreender a canção". Nesse âmbito, seguindo a compreensão pretendida das canções com a poética japonesa aqui abordadas, podemos considerar que elas têm em comum a manifestação de uma esfera meditativa por meio do uso de estruturas minimalistas e pentatonismos. Isto se deve pela busca do vazio e do silêncio enquanto criação musical. São desta forma, frutos da necessidade intrínseca de uma época - o Zeitgeist -, ou seja, experimentações em busca de novas linguagens como tendências estéticas da música do século $\mathrm{XX}$.

Para o cantor, todos esses resultados de investigação são fundamentais em um processo empírico interno que se concretiza tão somente na execução. Portanto, dialogar em profundidade com essas canções proporciona um enriquecimento oculto na esfera da voz interna que se reproduz ampliando a reverberação da voz externa. Essa voz, resultado da fusão de inúmeros horizontes, ecoa em dimensões invisíveis, mas pode ser ouvida somente aos sentidos de quem a escuta. A voz é o retrato íntimo da alma, projeção dos desejos e fantasias da voz interior movida pelas pulsões em conjunção com a obra de arte a ser executada. Por vezes, formam-se bordas fictícias entre a voz e a voz interior, um verdadeiro campo de batalha para o cantor. O cantor dotado deve ser, antes de tudo, um misto de guerreiro, sacerdote e curandeiro para ser um eficiente estrategista e administrador de si próprio. 
Finalmente, mais do que compreender a canção no âmbito acadêmico (racional), é preciso transcender todos os aspectos dos contextos históricos e filosóficos, da notação musical, das tessituras, das palavras e dos timbres sonoros da obra que devem se harmonizar com os aspectos físicos, psíquicos e espirituais do ato de cantar, tentando não necessariamente entender, mas sentir a essência da canção.

Sem senti-las, nada se justifica. E é com esse sentir e com essa vivência que se amenizam as bordas fictícias ou imaginadas entre Brasil e Japão, do mundo interior e exterior, do racional e afetivo, da análise musical e performance. Cantar integrando-se com a obra, o mundo, a natureza e o si próprio, é percorrer um caminho repleto de descobertas sem fim. Não obstante, o canto é a expressão mais profunda da existência, quando se transforma no grito de nascimento de cada sentir, que emerge das entranhas. O canto nos faz, assim, pensar com o coração. 
REFERÊNCIAS BIBLIOGRÁFICAS 
ANDERSON, B. Comunidades imaginadas. Tradução de Denise Bottman. São Paulo: Companhia das Letras, 2008 [1ª ed. Inglesa, 1983].

ANDRADE, M. Ensaio sobre a Música Brasileira. São Paulo: Livraria Martins Editora, 1928.

ASQUITH, P. J.; KALLAND, A. Japanese images of nature: cultural perspectives. London : Routledge Curzon, 2004.

BONNARDOT, J. Le professeur de chant: um luthier qui construit une voix. Paris: Editions Henry Lemoine, 2004.

CAGE, J. Silence: Lectures and Writing by John Cage. Connecticut: Wesleyan University Press, 1961.

CAMPOS, H. (org.). Ideograma: Lógica, Poesia Linguagem. Tradução dos textos por Heloysa de Lima Dantas. São Paulo: EDUSP, 2000. [4ª . edição].

CAMPOS, A.; PIGNATARI, D.; CAMPOS, H. Teoria da poesia concreta. São Paulo: Ateliê, 2006.

COSTA, V. F. Vinholes e Cage: teorias, indeterminação e silêncio. (Tese de Doutorado). Universidade Estadual de Campinas, Campinas, 2005.

FORBES, J. Você quer o que deseja? São Paulo: Best Seller, 2004 [4ª edição]. 2003 [1ª. Edição].

GADAMER, H. G. Verdade e método. Tradução de Flávio Paulo Meuer.

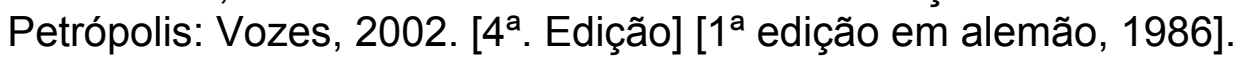

GEERTZ, C. A interpretação das Culturas. Rio de Janeiro: Livros Técnicos e Científicos, 1989. 
GIROUX, S. M. Zeami: cena e pensamento Nō. São Paulo: Perspectiva, 1991.

KIMBALL, C. Song: a guide to art song style and literature. Milwaukee: Hal Leonard, 2006.

KOELLREUTTER, H. J. À procura de um mundo sem "vis-à-vis" - reflexões estéticas em torno das artes oriental e ocidental. São Paulo: Novas Metas Ltda, 1983.

LAMBOURNE, L. Japonisme: Échanges culturels entre le Japon et l'Occident. Paris: Phaidon, 2007. [1ª edição francesa 2006].

MACHADO NETO, D. A Semana de 22 de uma viagem pelo interior de São Paulo (cópia datilografada do trabalho apresentado no I Encontro de Musicologia de Ribeirão Preto). Ribeirão Preto: Departamento de Música de Ribeirão Preto da ECA-USP, 2003.

MAIA, M. S. Serialismo, Tempo-Espaço e Aleatoriedade: a obra do compositor Luiz Carlos Lessa Vinholes. (Dissertação de Mestrado). Pontifícia Universidade Católica do Rio Grande do Sul, Porto Alegre, 1999.

MASON, P. History of Japanese art. New Jersey: Pearson Education Inc, 2005. [1a. edição Americana 1993].

MASSIM, J.; MASSIM, B. História da música ocidental. Tradução de Maria Teresa Resende Costa, Carlos Sussekind, Angela Ramalho Viana. Rio de Janeiro: Nova Fronteira, 1997 [1ª edição francesa 1983].

MENDES, G. Música moderna brasileira e suas implicações de esquerda. Revista Música, São Paulo: Departamento de Música da ECA-USP, v. 2, nº 1, p. 37-42, 1991.

MERRIAM, A. P. The Anthropology of Music. Evanston: Northwestern University Press, 1964. 
NAKANO, I. The Development of "Shōka Education in Japan. In: 101 Favorite Songs Taught in Japanese Schools. Tokyo: The Japan Times, 1983.

ORLANDI, E. P. As formas do silêncio: no movimento dos sentidos. Campinas: Editora da UNICAMP, 2007.

ORTIZ, R. O próximo e o distante. Japão e modernidade - mundo. São Paulo: Editora Brasiliense, 2000.

PAREYSON, L. Os problemas da estética. Tradução de Maria Helena Nery Garcez. $3^{a}$ ed. São Paulo: Martins Fontes, 1997 [1ª ed. Italiana 1966].

PERSICHETTI, V. Twentieth-century harmony: Creative aspects and practice. New York: W. W. Norton \& Company, 1961.

RICOEUR, P. Interpretação e Ideologias. Organização, tradução e apresentação de Hilton Japiassu. Rio de Janeiro: Francisco Alves, 1990.

ROSEN, C. A geração romântica. Tradução de Eduardo Seincman. São Paulo: EDUSP, 2000. [1 ${ }^{\text {a }}$ ed. Americana 1995].

STEIN, D; SPILLMAN, R. Poetry into song. New York: Oxford University Press, 1996.

STRAVINSKY, I. Poética musical em seis lições. Tradução de Luiz Paulo Horta. Rio de Janeiro: Jorge Zahar, 1996, p. 26, 89-108.

SUZUKI, T. As expressões de tratamento da língua japonesa. São Paulo: EDUSP, 1995.

SUZUKI, D. T. Zen Buddhism. New York: William Barret, 2006.

TSUBAKI, A. A. Zeami and the transition of the concept of Yugen: A note on japanese aesthetics. The Journal of Aesthetics and Art Criticism, v. 30, $n^{\circ} 1$, p. 55-67, 1971.

WILLMS, J. Paris: from the revolution to the Belle Époque. New York/London: Holmes \& Meier, 2002. 
Sitiografia

ACADEMIA BRASILEIRA DE LETRAS. Luis Guimarães Filho. Disponível em http://www.academia.org.br/abl/cgi/cgilua.exe/sys/start.htm?infoid=706\&sid=24 ‥ Acesso em 20/04/2009.

BITONDI, M. Um mestre da música contemporânea no Brasil. Disponível em http://pphp.uol.com.br/tropico/html/textos/2492,1.shl Acesso em 05/06/2009.

PONDÉ, L. F. P. Blábláblá. In: Jornal Folha de São Paulo, llustrada, 2 de março de 2009. Disponível em http://raulmarinhog.wordpress.com/2009/03/ 02/relativismo-cultural-a-crise-nos-eua/. Acesso em 20/04/2009.

TACUCHIAN, R. Paidéia Musical: Introdução à vida e obra de Heitor VillaLobos. 2008. Disponível em http://paideiamusical.blogspot.com/2008/10/ introduo-vida-e-obra-de-heitor-villa.html. Acesso em 5/03/2009.

VALENTE, H. A. D. Música é informação! Música e mídia a partir de alguns conceitos de Paul Zumthor. Anais do V Congresso Latinoamericano da Associação Internacional para o Estudo da Música Popular - Rio de Janeiro 2004. Disponível em: http://www.hist.puc.cl/iaspm/rio/Anais2004\%20(PDF)/ HeloisaValente.pdf. Acesso em: 20/08/2008.

VINHOLES, L. C. L. Intercâmbio, Presença e Influência da Poesia Concreta BrasileiranoJapão. 2007a. Disponível em: http://www.usinadeletras.com.br/ exibelotexto.php?cod=44114\&cat=Artigos\&vinda=S 2007 - acesso em 05 de junho de 2007.

VINHOLES, L. C. L. Poesia Concreta Brasileira, 2007b. Disponível em: http//www.fjsp.org.br/guia/cap09 j.htm. Acesso em 12/06/2007.

A Odisséia Musical de Gilberto Mendes. DVD. Produção Berço Esplêndido. Carlos de Moura Ribeiro Mendes (direção). Gravações realizadas entre 2002 e 2005. 
ANEXOS

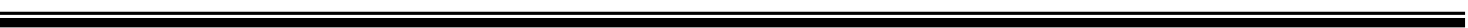




\section{ANEXO 1:}

\section{O MEU AMIGO KOELLREUTTER}
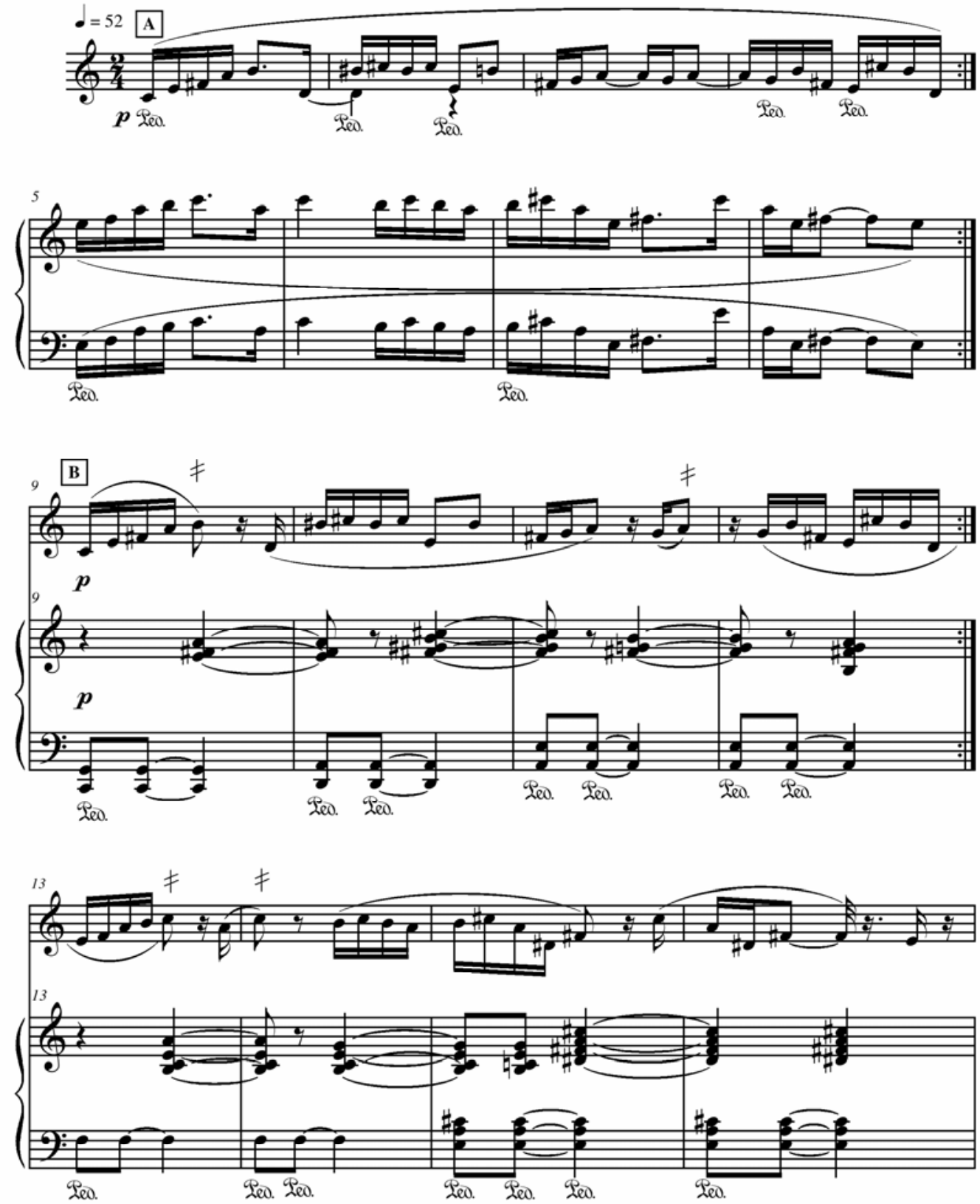

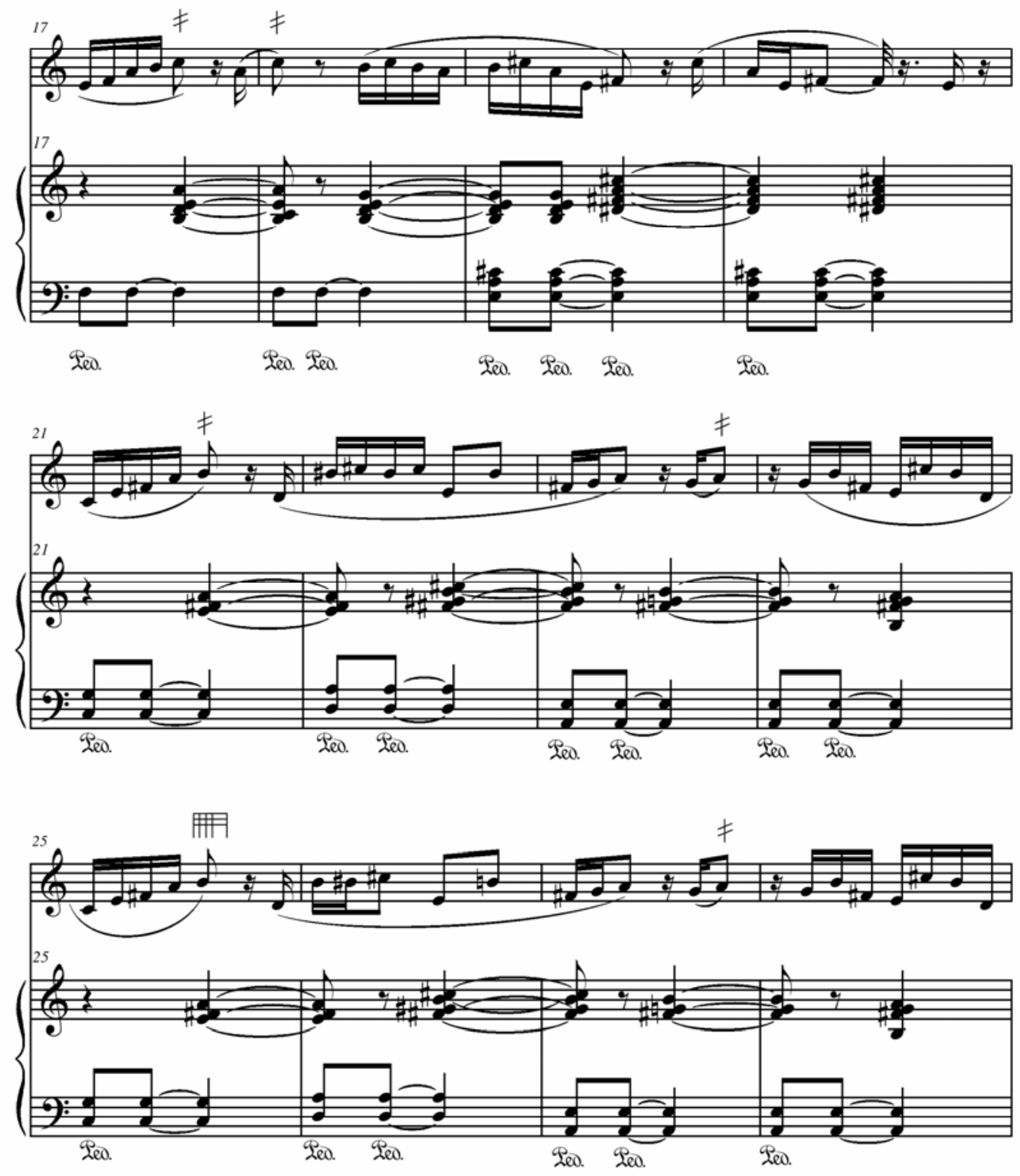

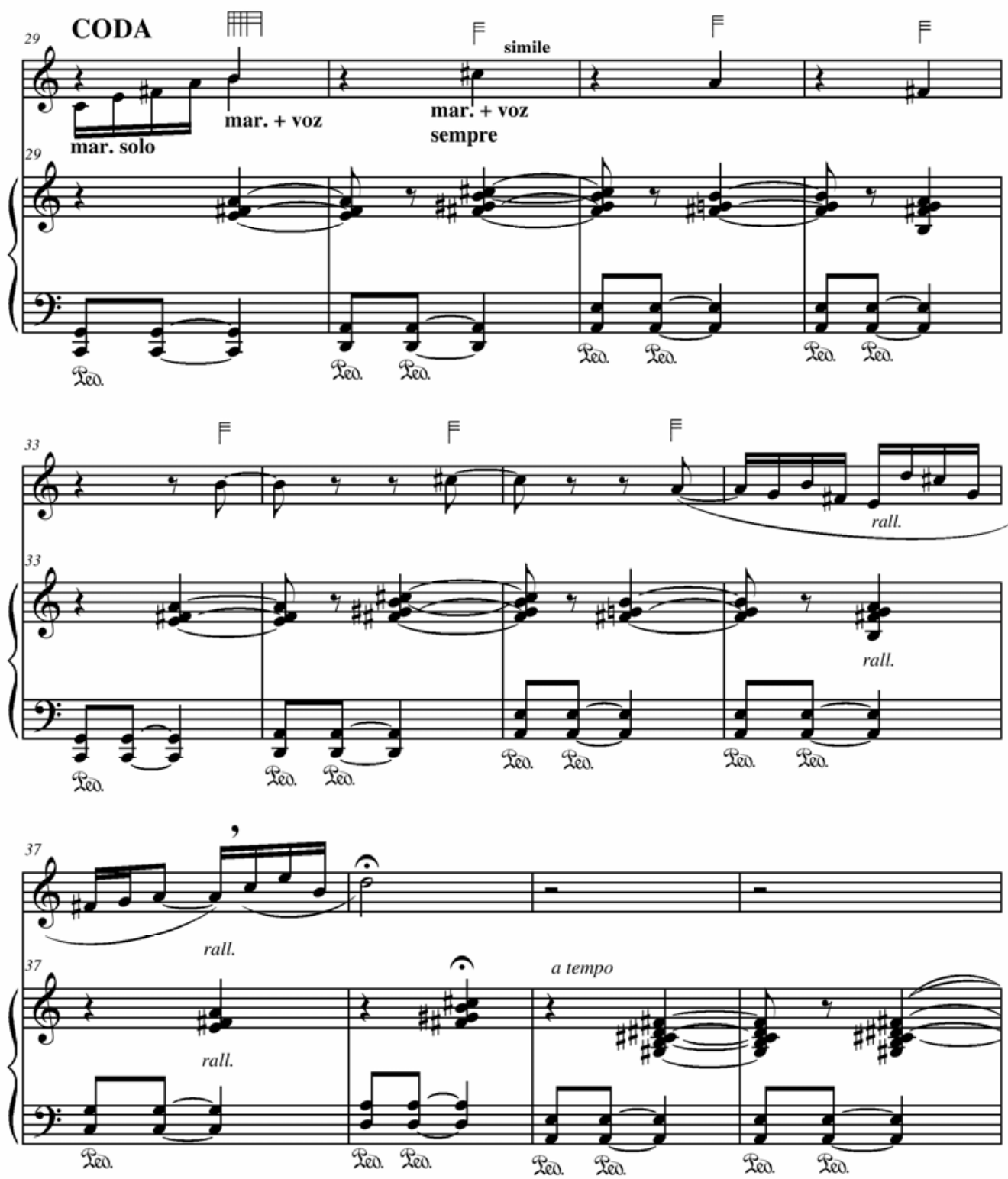


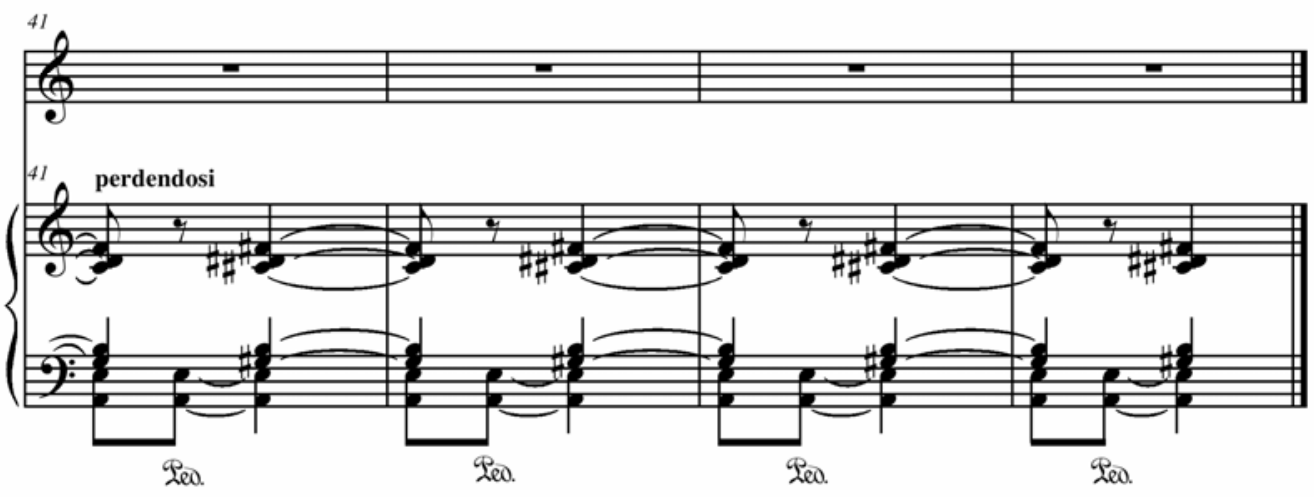

- Para piano, voz feminina e marimba (em uníssono) com baquetas de feltro trançado.

- Sempre piano, igualmente sonoro, tudo na mesma intensidade, tranqüilo, sem acentuar tempos fortes.

- Voz senza vibrato, como um instrumento, bem legato, canta sobre a vogal "a", com a boca preparada para "o".

- Marimba realiza: $\neq$ tremolo sobrea nota indicada e 冊 (símbolo abreviado $F$ ) este ritmo.

- Ordem de execução: A B B1 B2 Coda, somente na parte B repetir 4 vezes os 4 compassos iniciais, isto é, dobrar o ritornello.

Esta peça comemora os 70 anos do Prof. H. J. Koellreutter em 1985. 


\section{ANEXO 2:}

\section{JAPONÊSAS}

Poesia de

Luiz Guimarães Filho

H. Villa Lobos, Op. 2

Miniaturas $\mathbf{n}^{\circ} \mathbf{5}$

(Bahia, 5-3-1912)
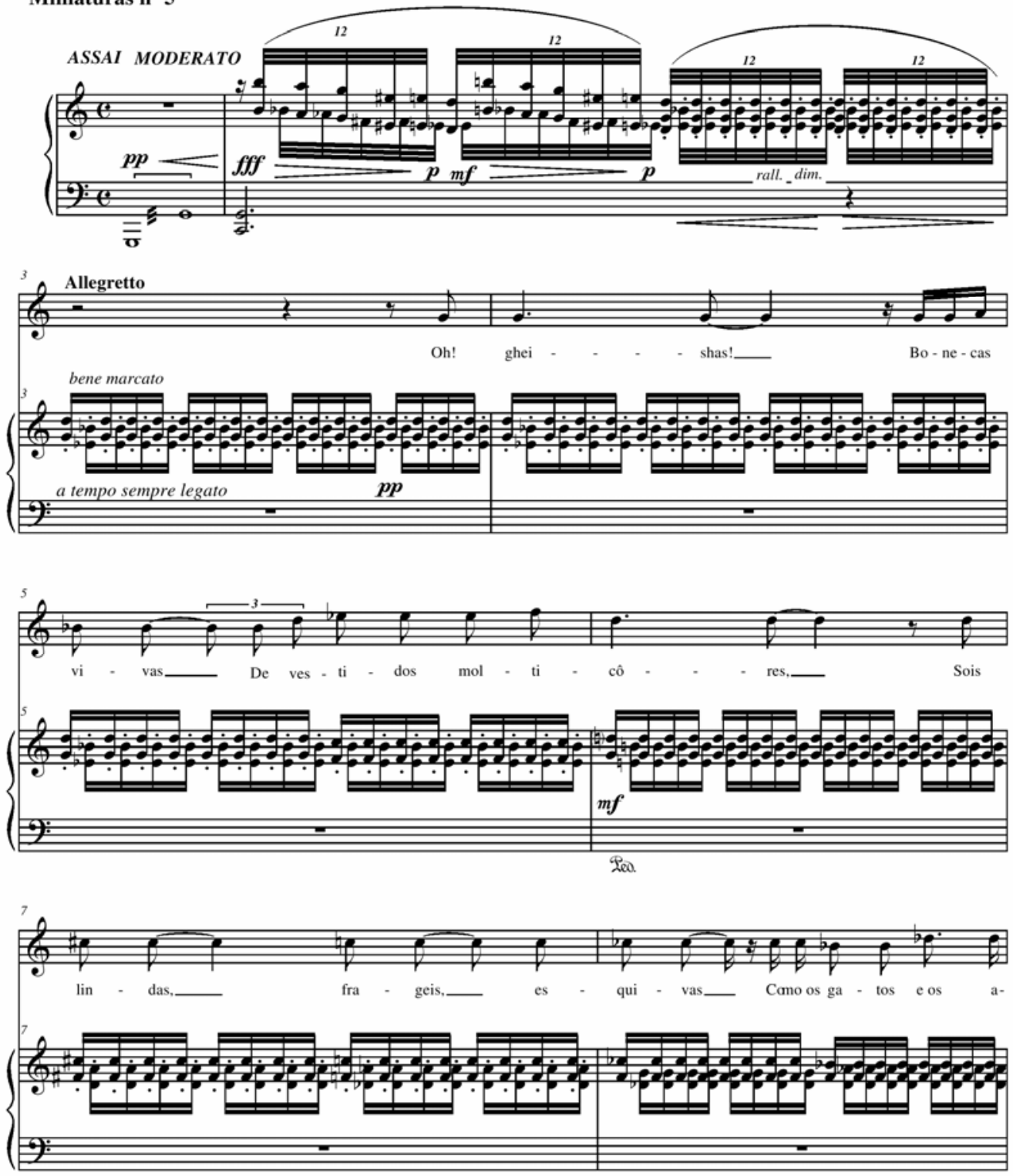

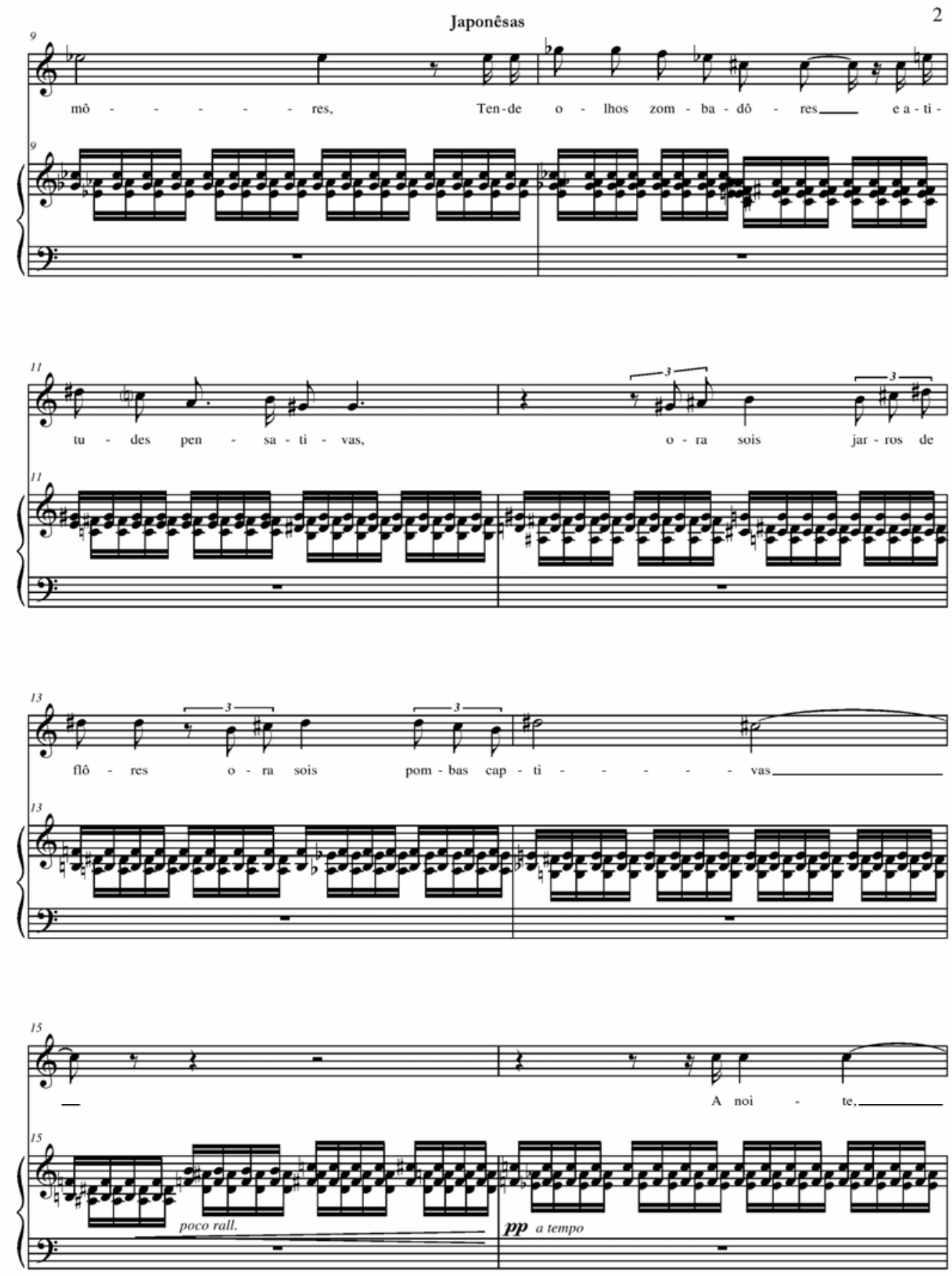

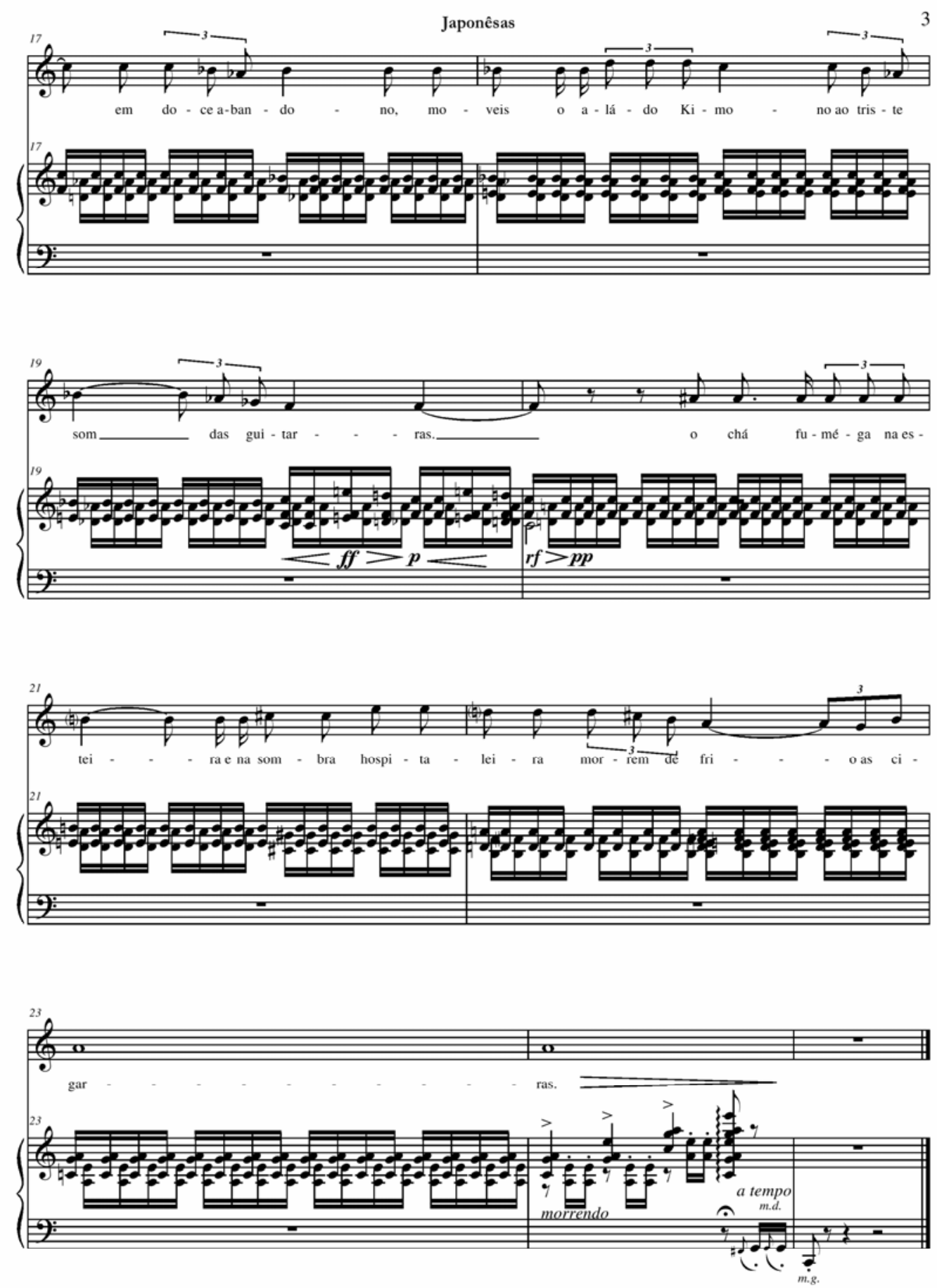


\section{ANEXO 3:}

\section{Ōtani Shōgakkō Ka}

Luiz Carlos Lessa Vinholes
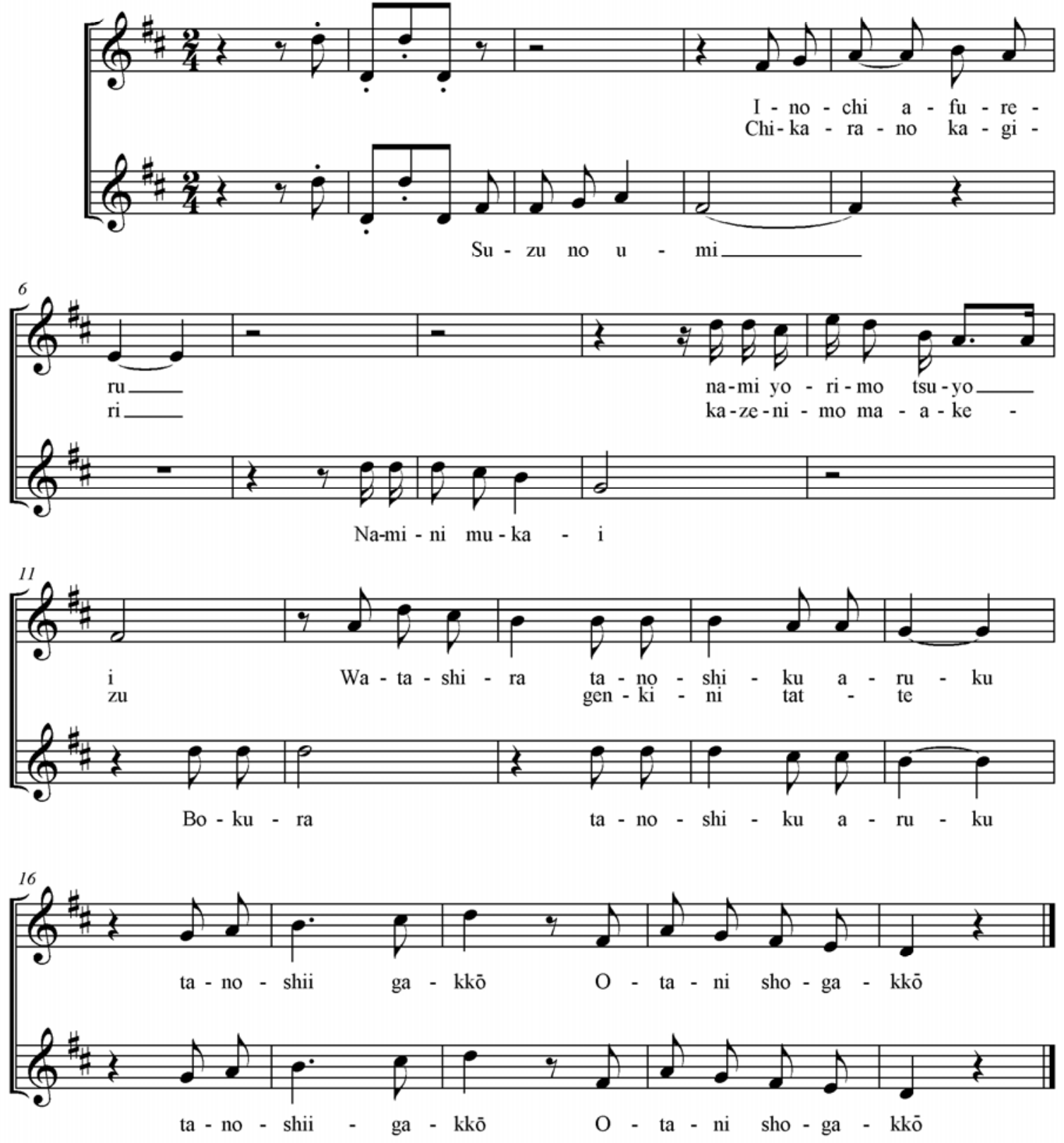


\section{ANEXO 4:}

\section{TANKA 1}

Takuboku Ishikawa
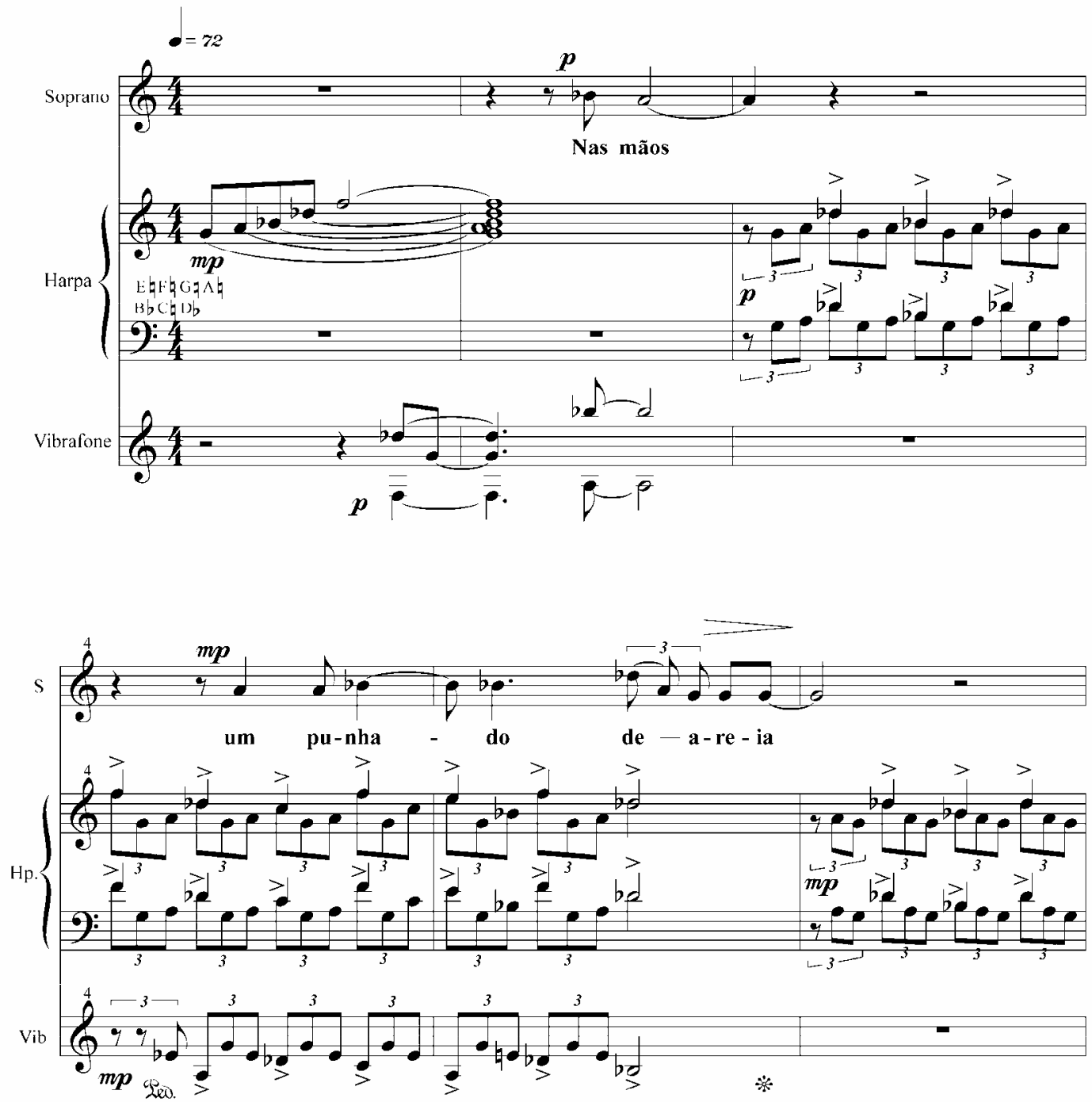

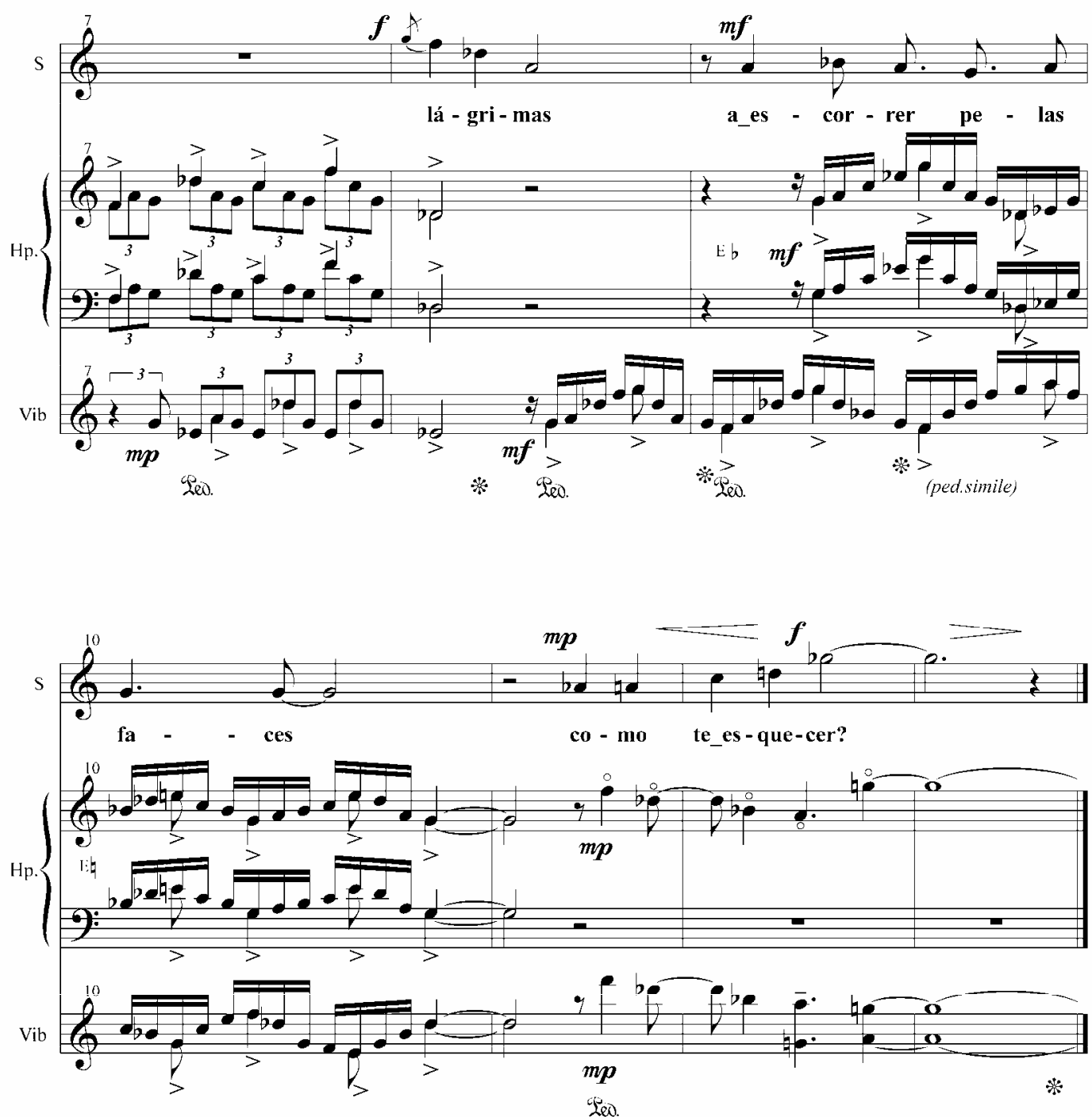
TANKA 2

Takuboku Ishikawa

Rodolfo Coelho de Souza
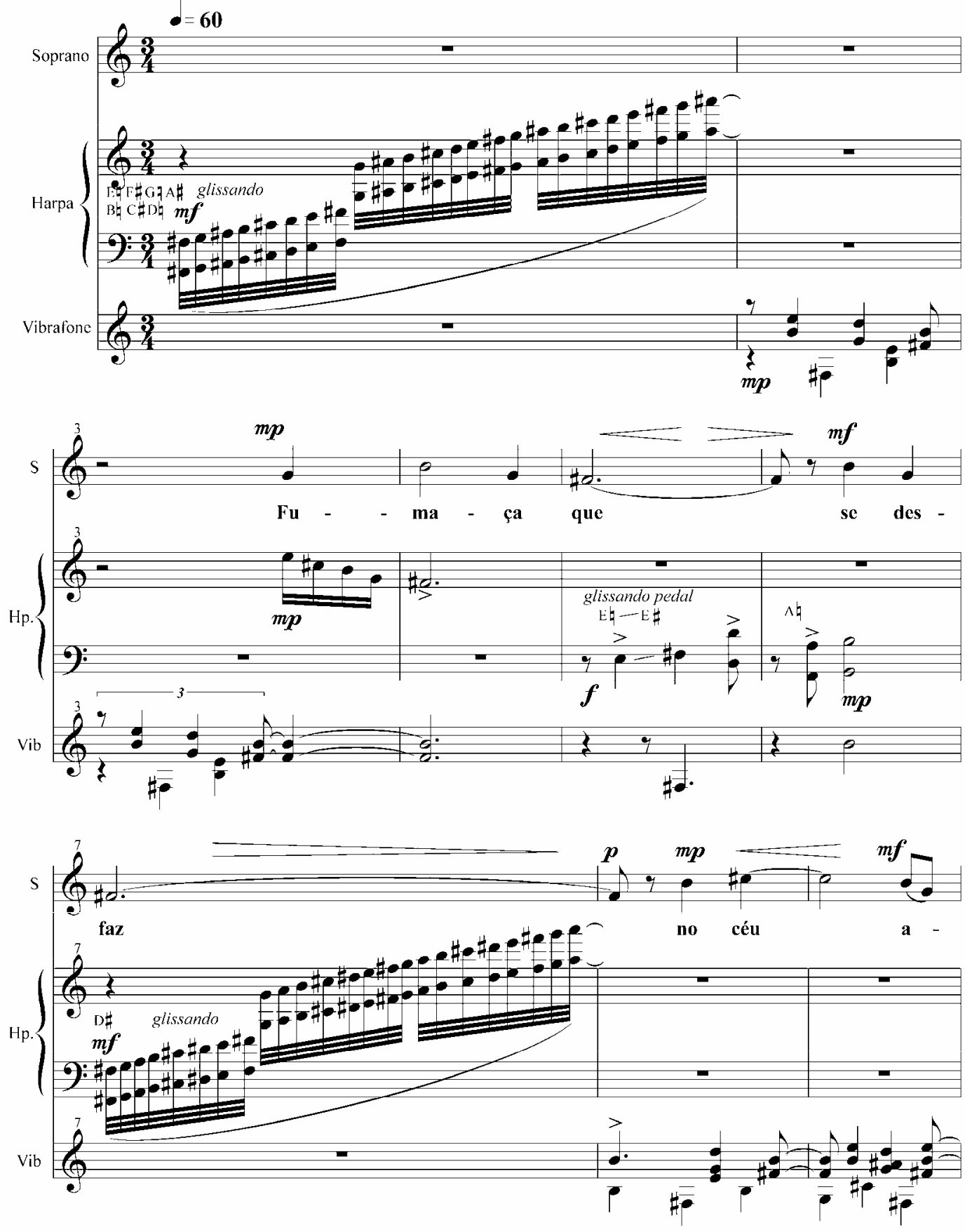

$-3-$ 

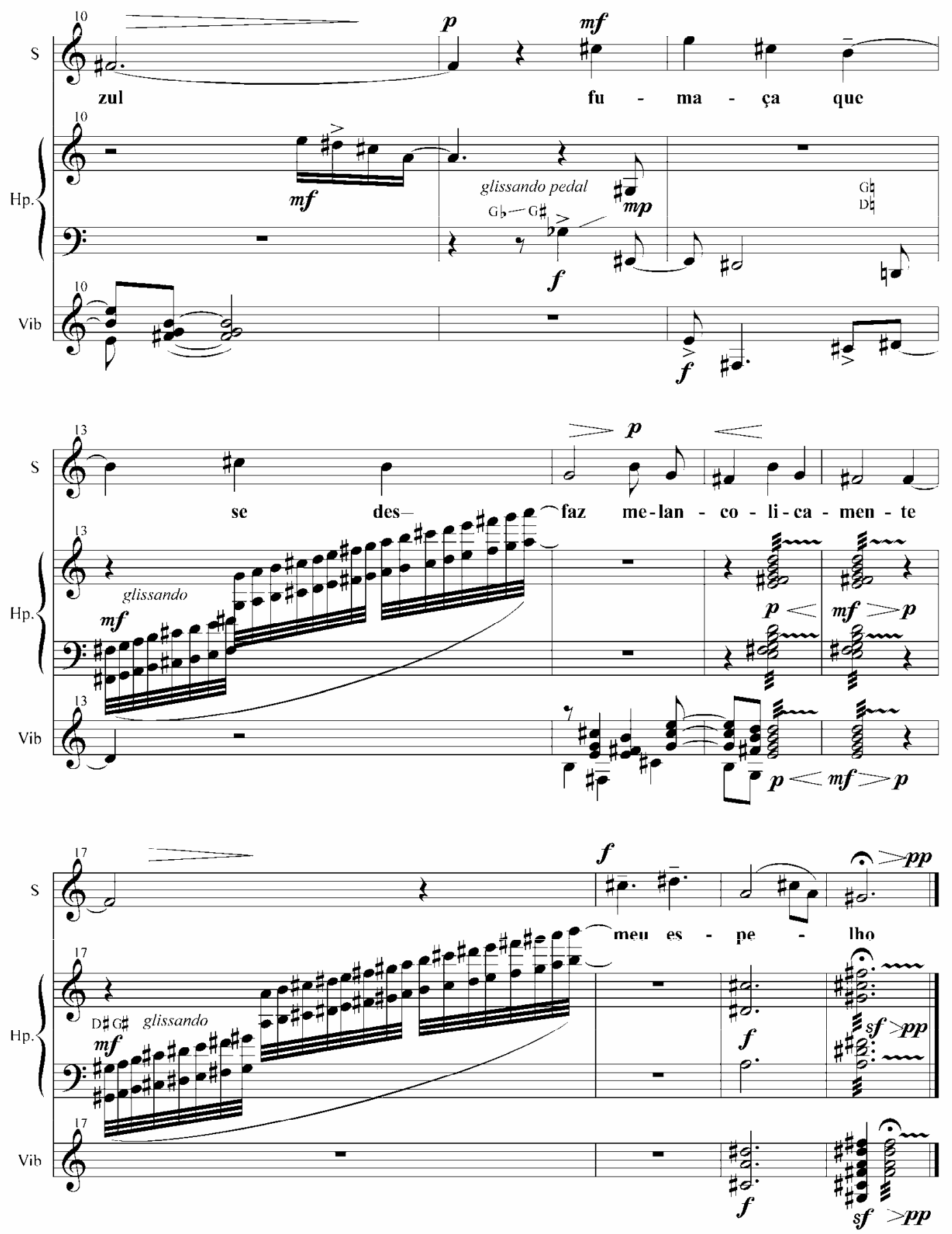

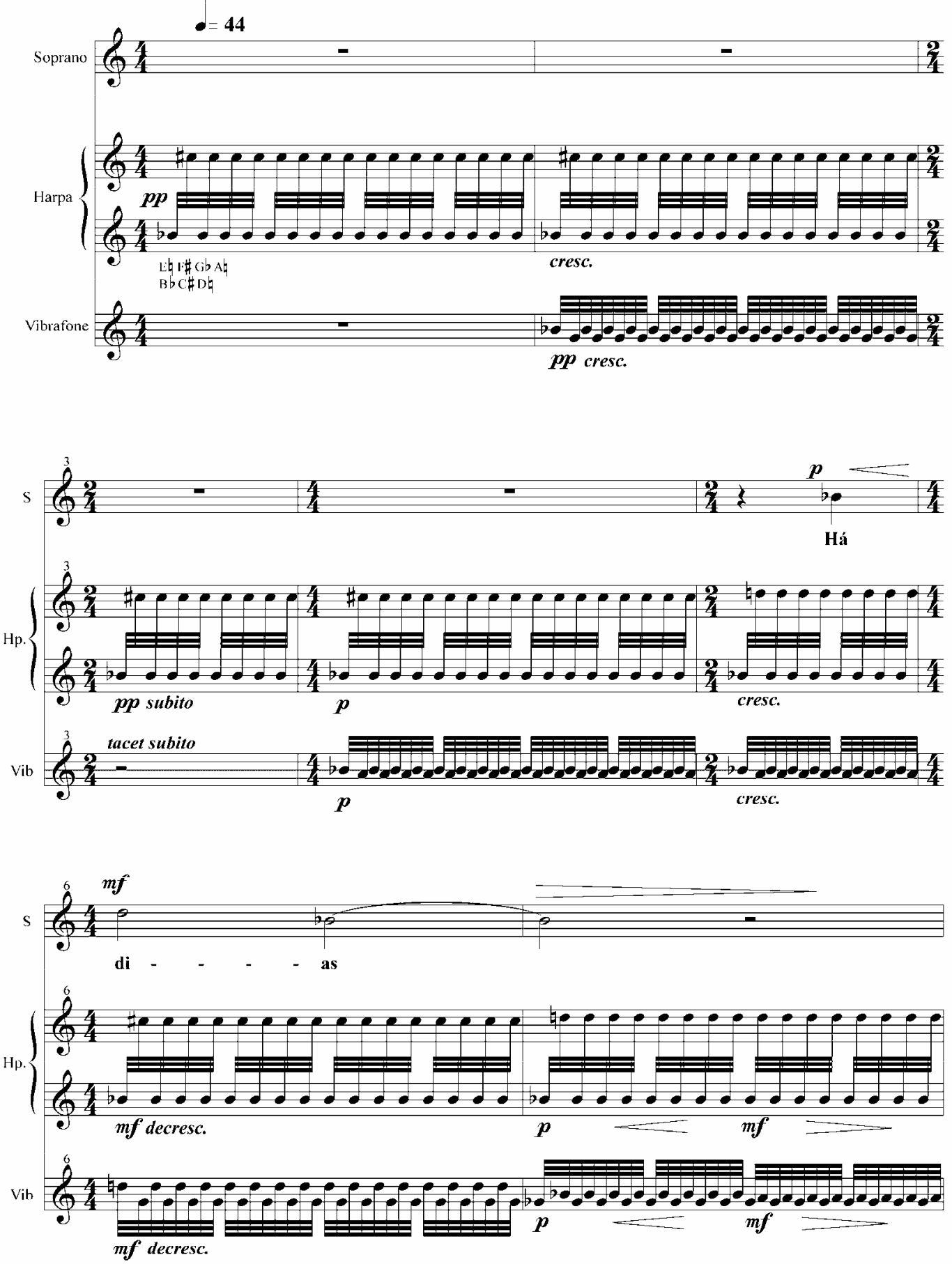

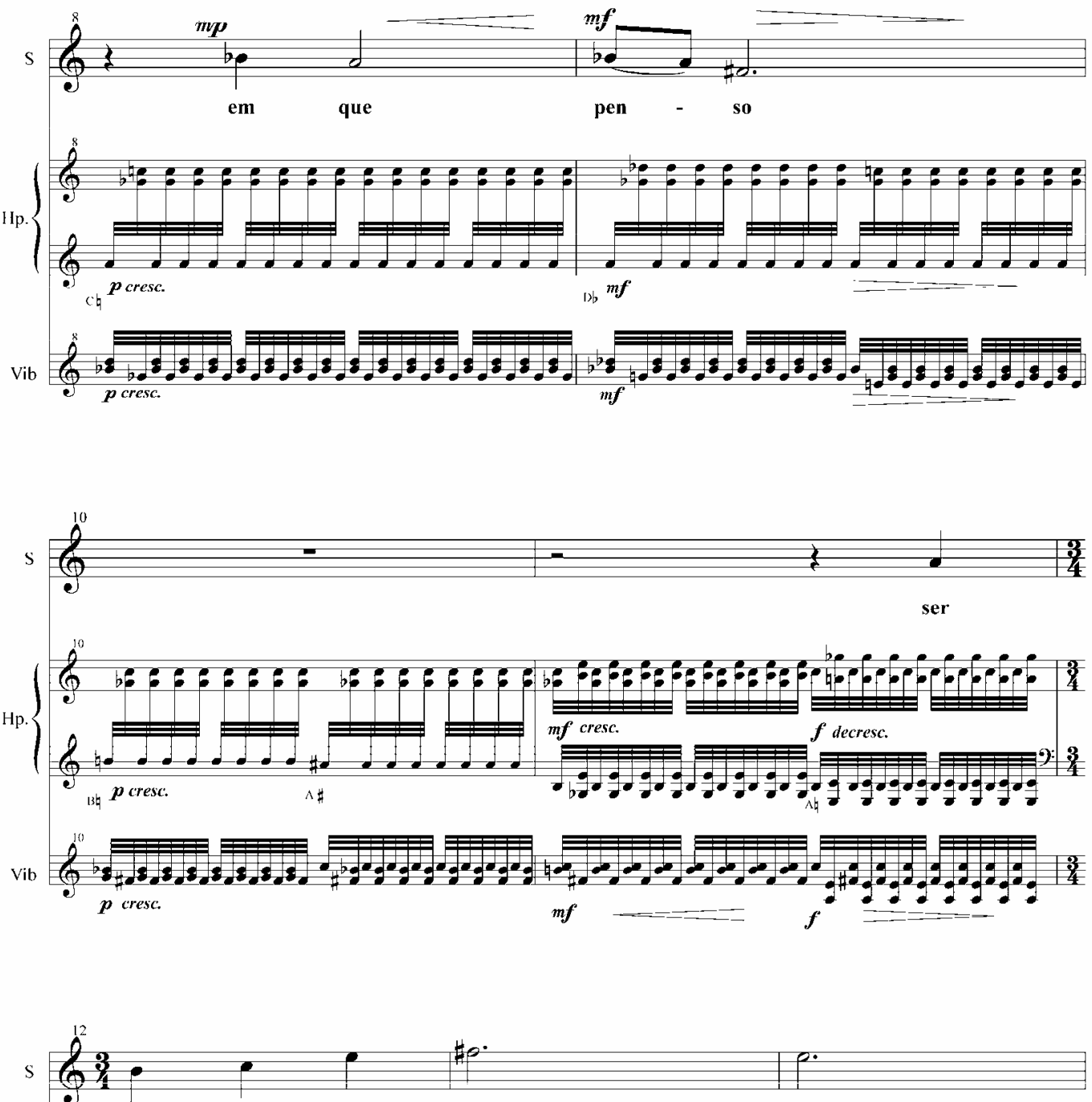
mi - nha lin - gua - $\quad$ - $\quad$ - $\quad$ - $\quad$ - gem

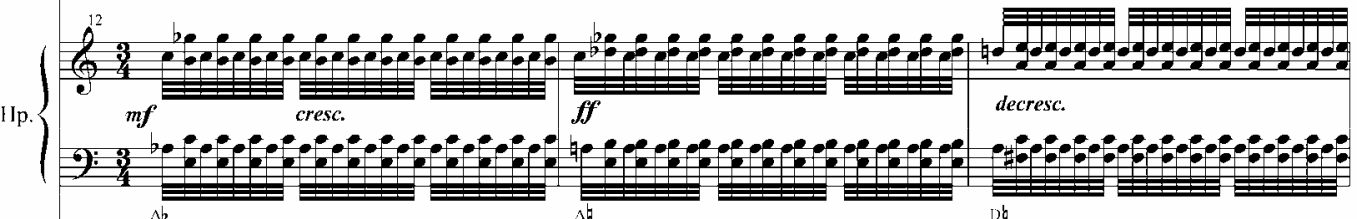

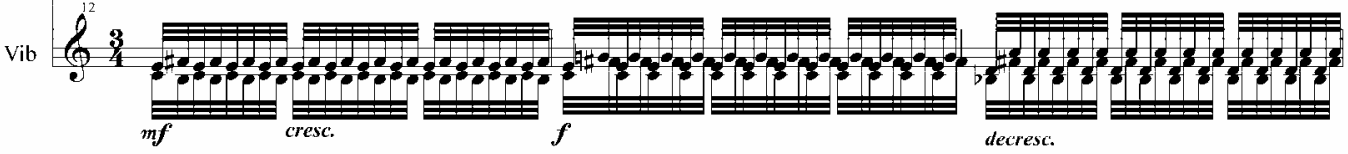



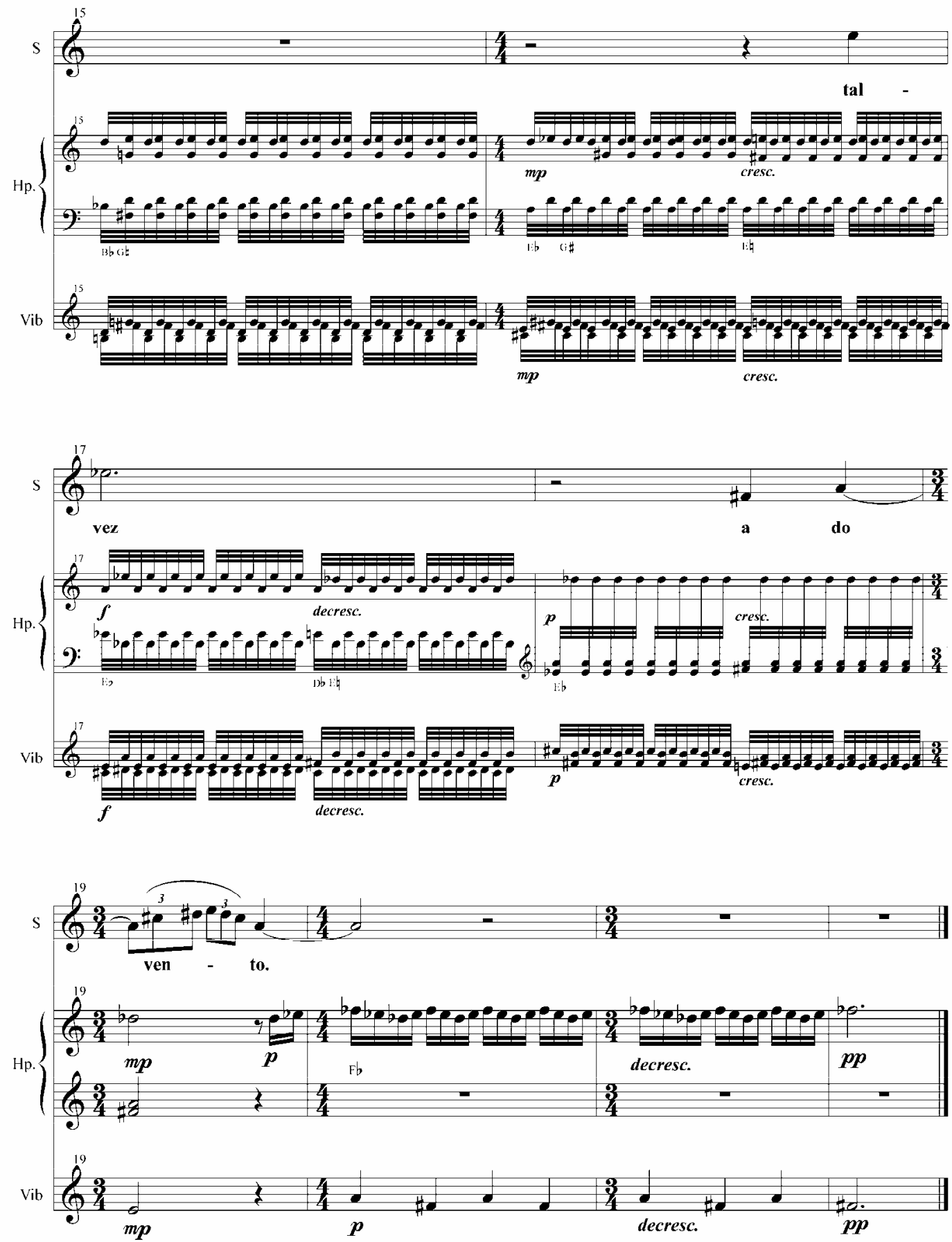

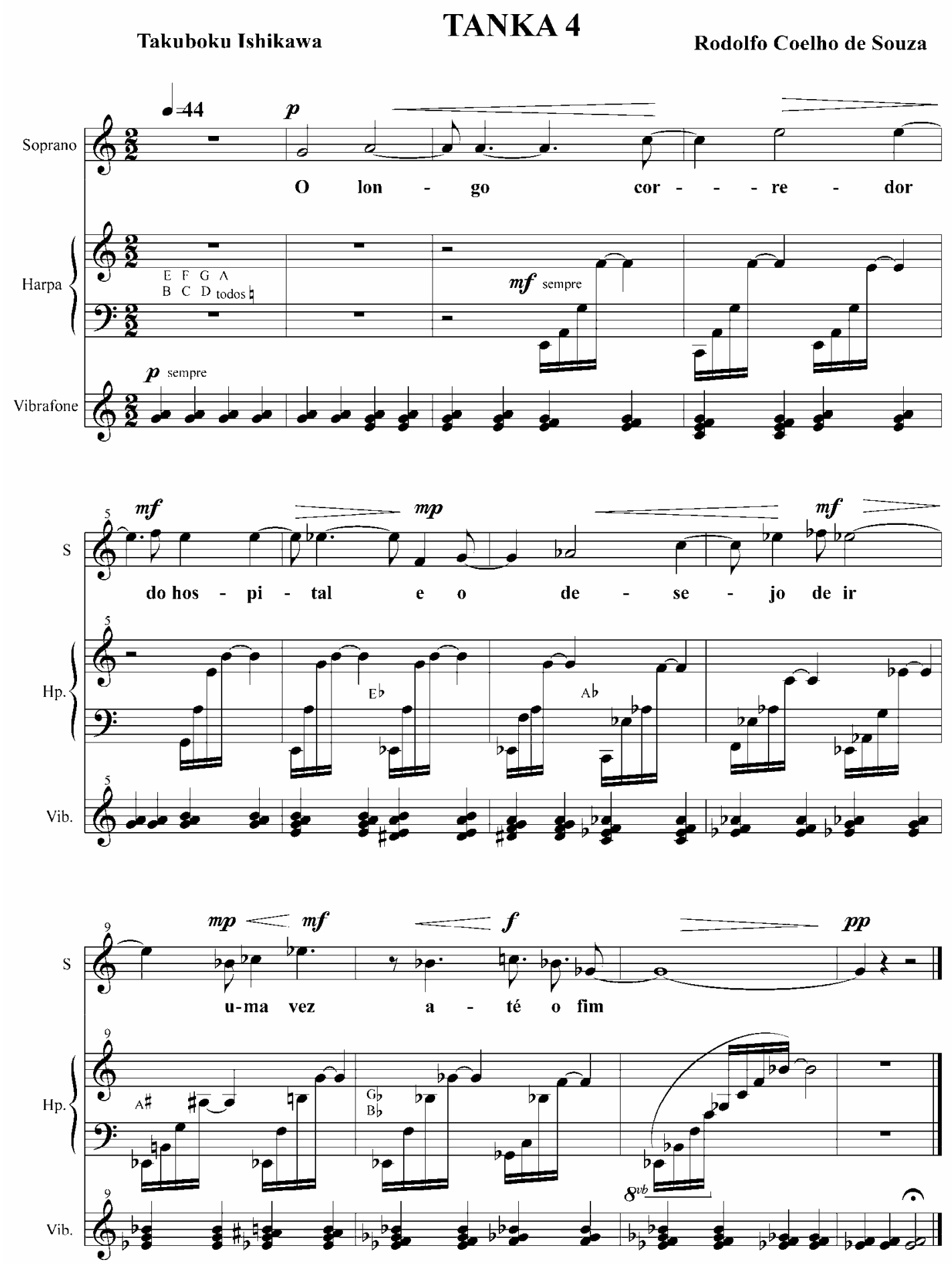
TANKA 5

Takubōoku İshikawa
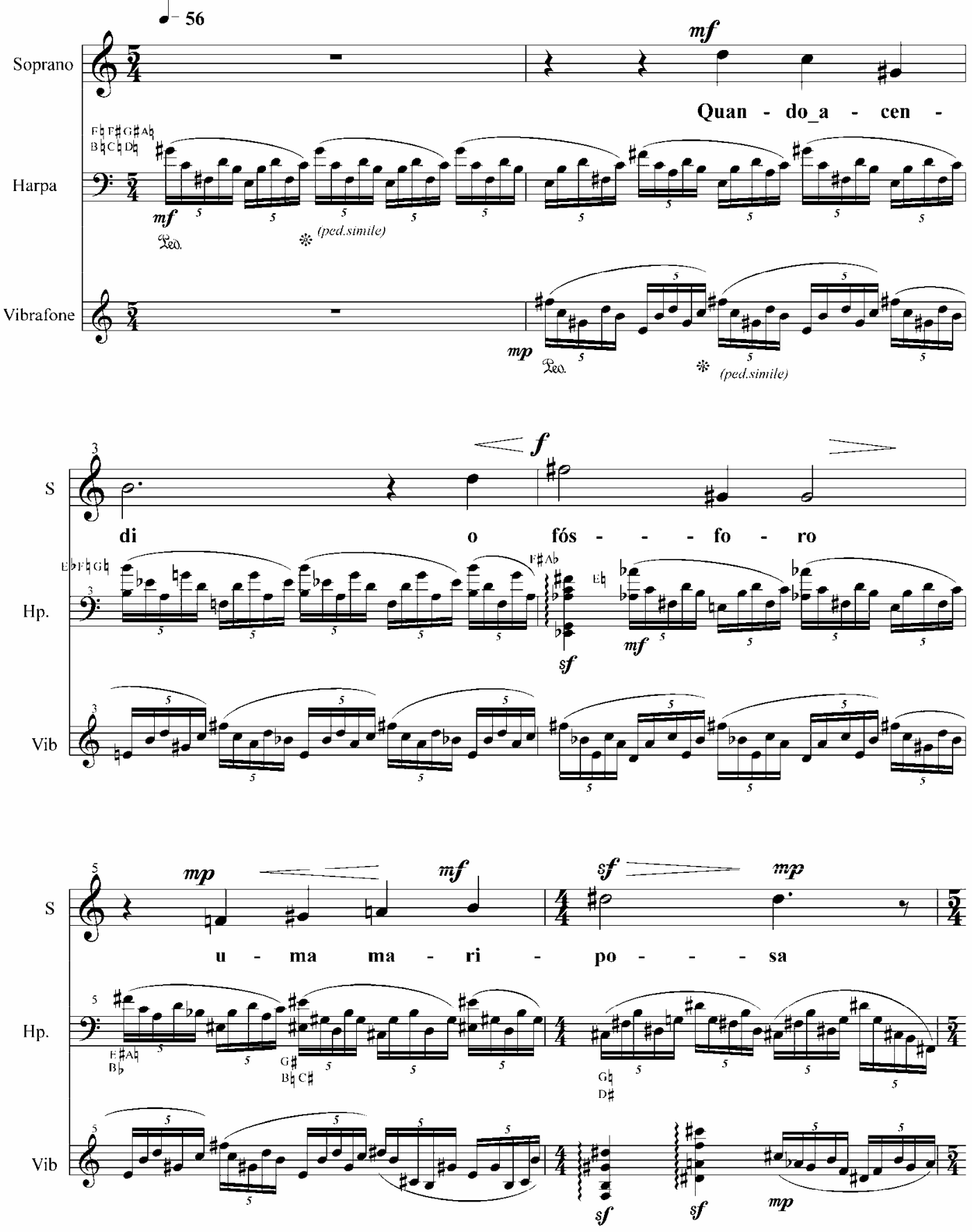


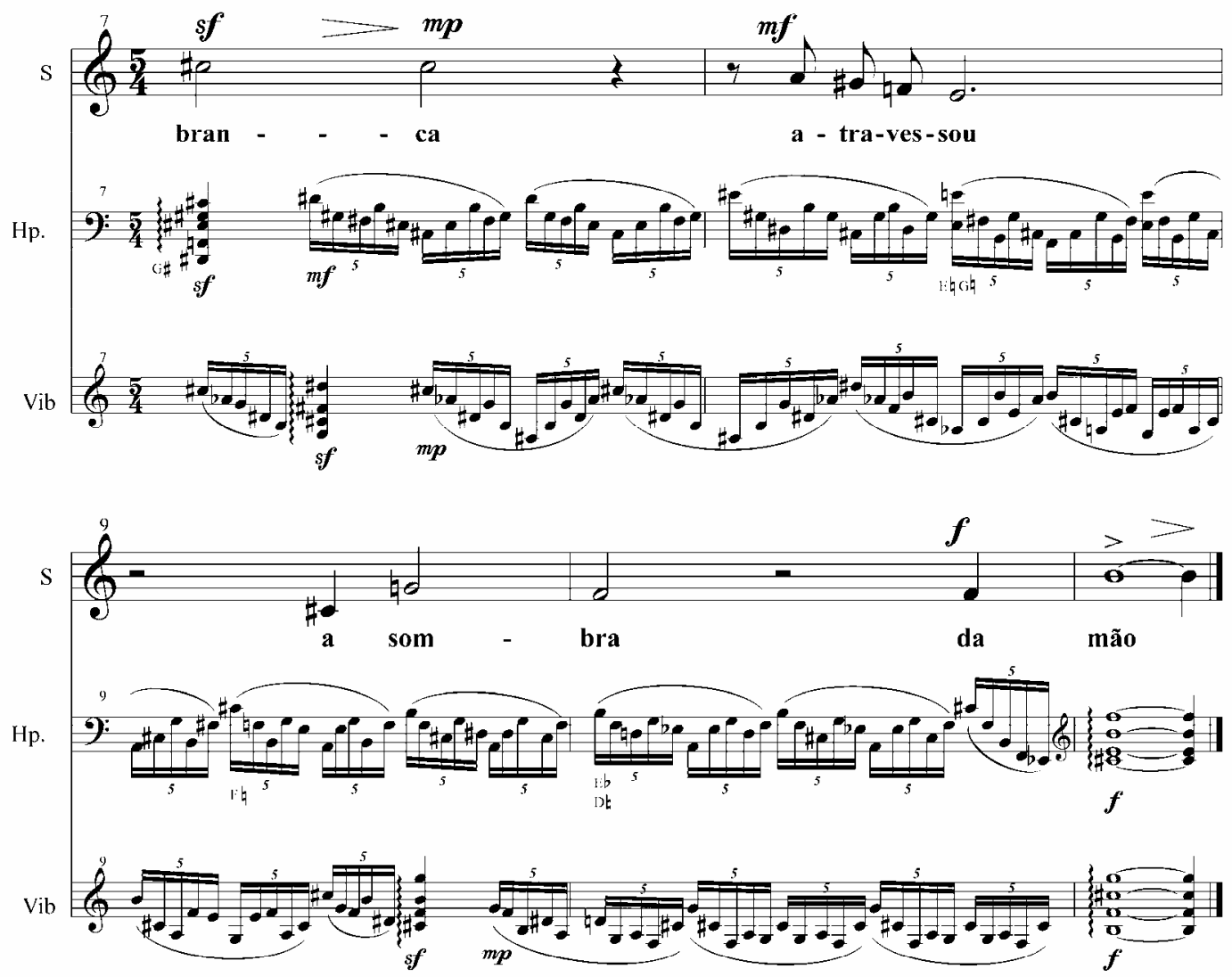




\section{ANEXO 5:}

\section{ACALANTO PARA NOEMI}

Almeida Prado Campinas $21 / 10 / 96$

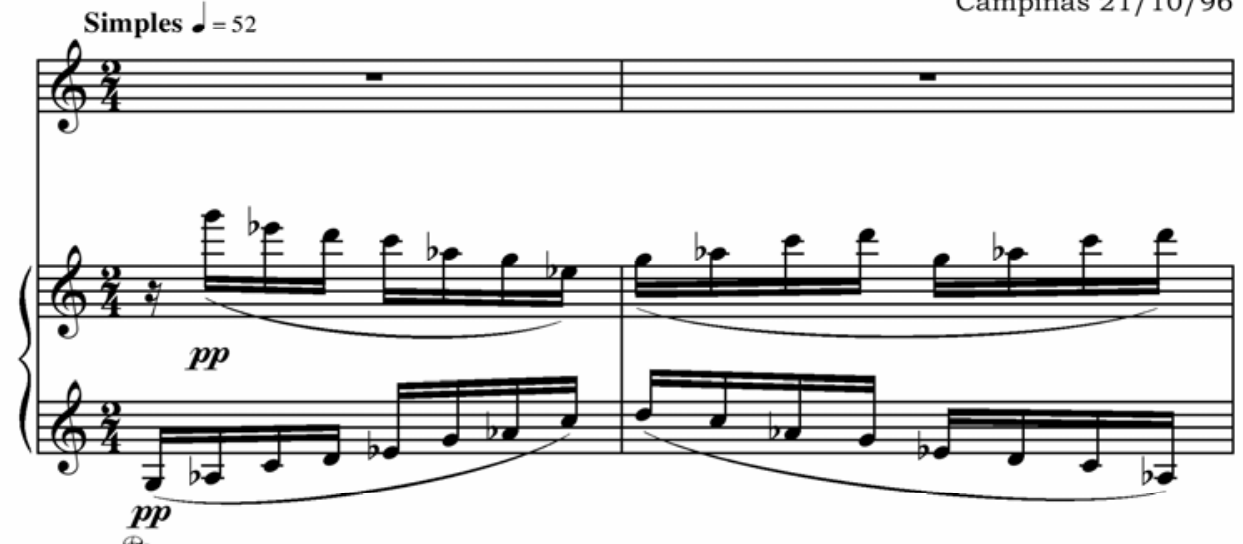

2eo. até o sinal * (Modo HIRAJOSHI - $3^{\mathrm{a}}$ transposição)
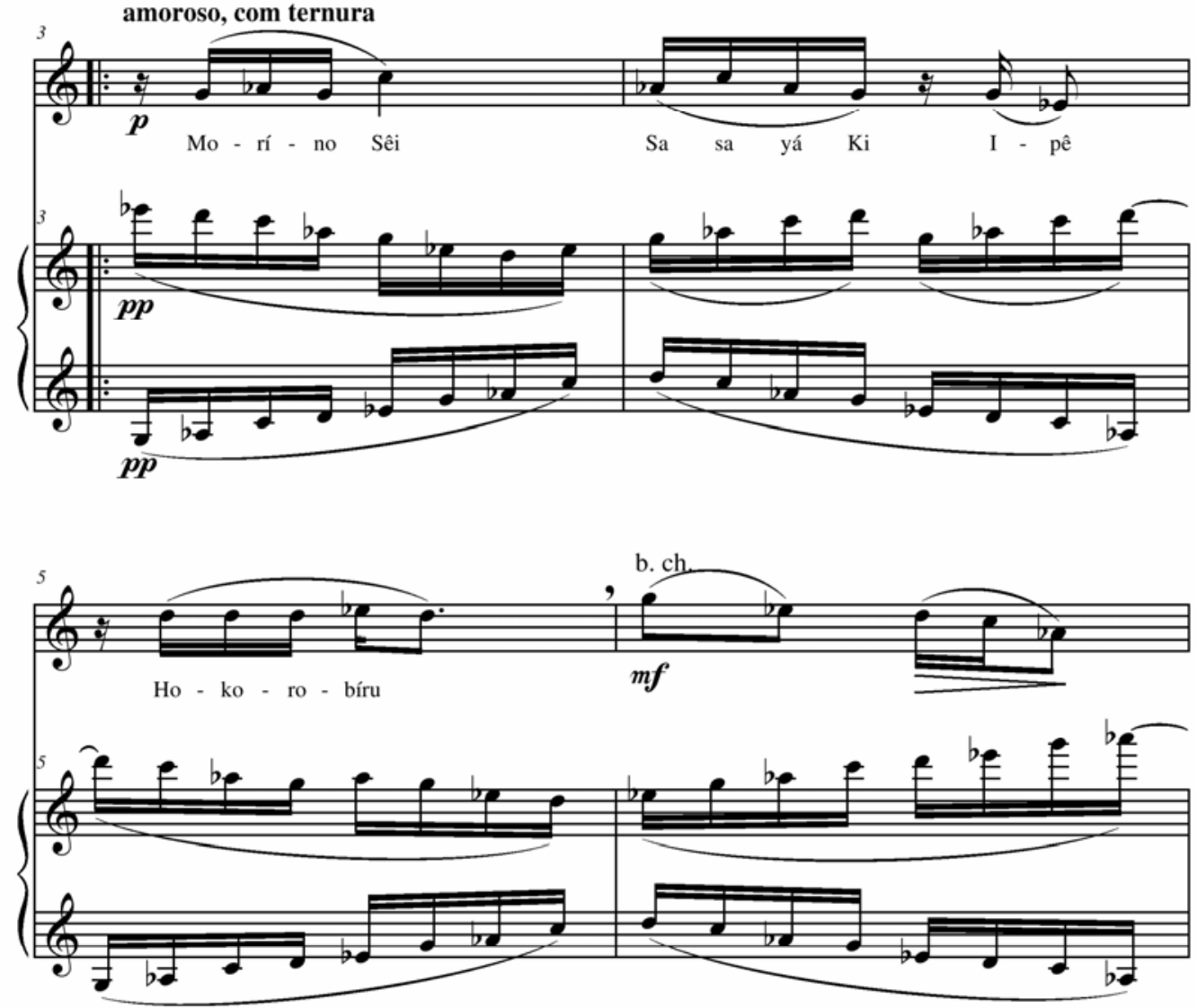

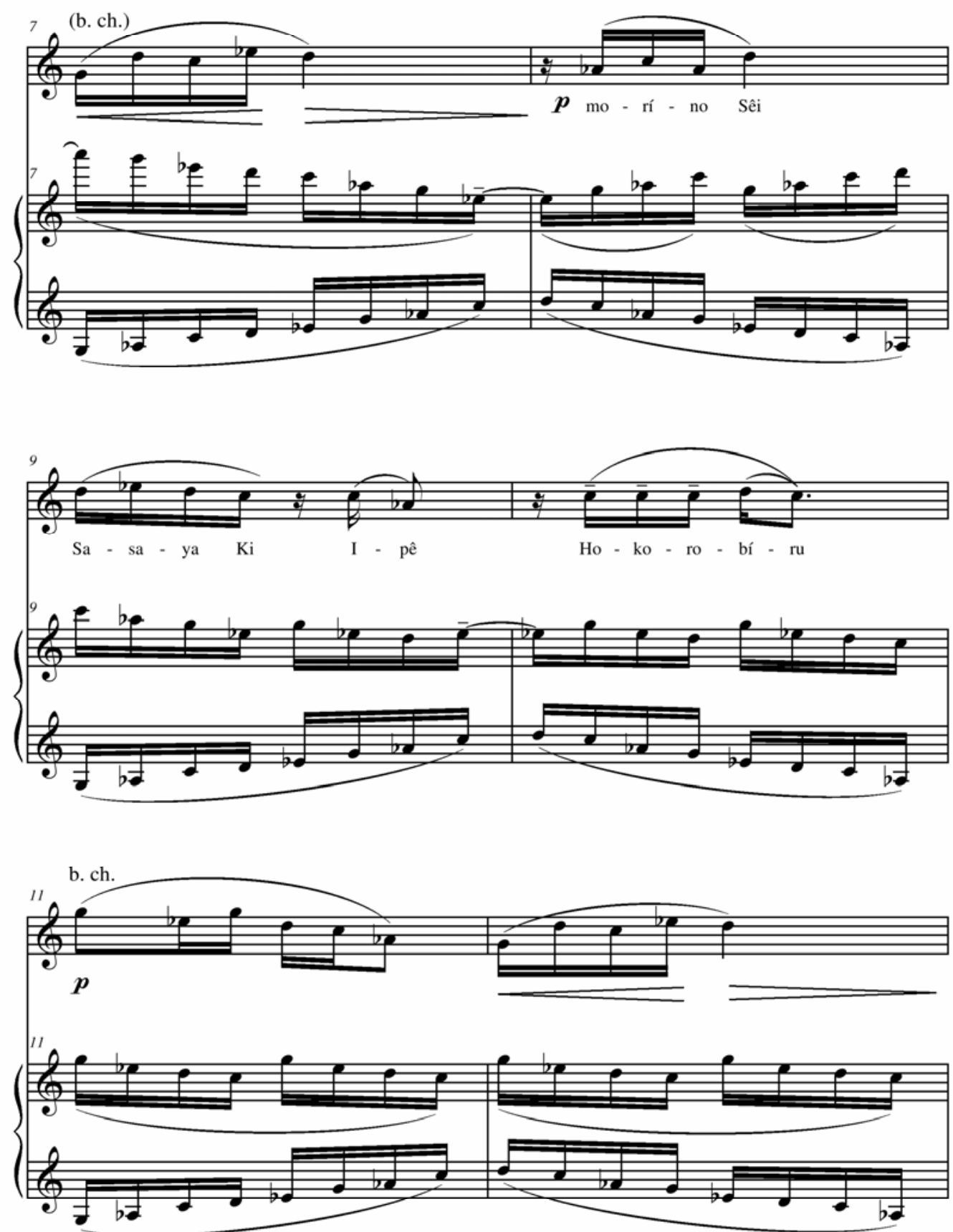


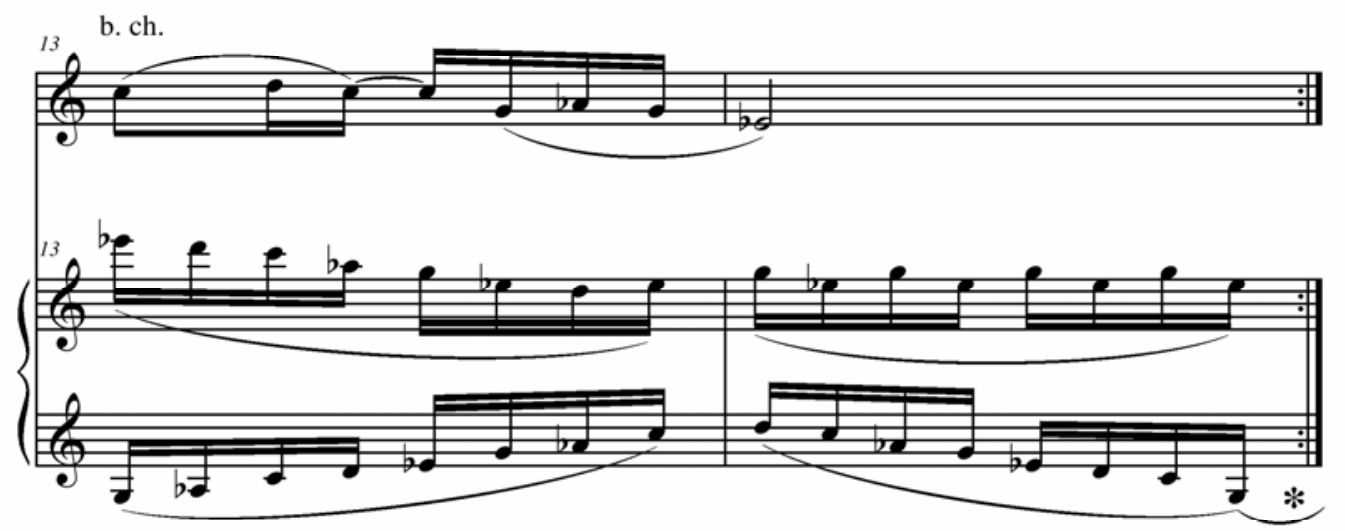
na repetição, ligar o Sol.

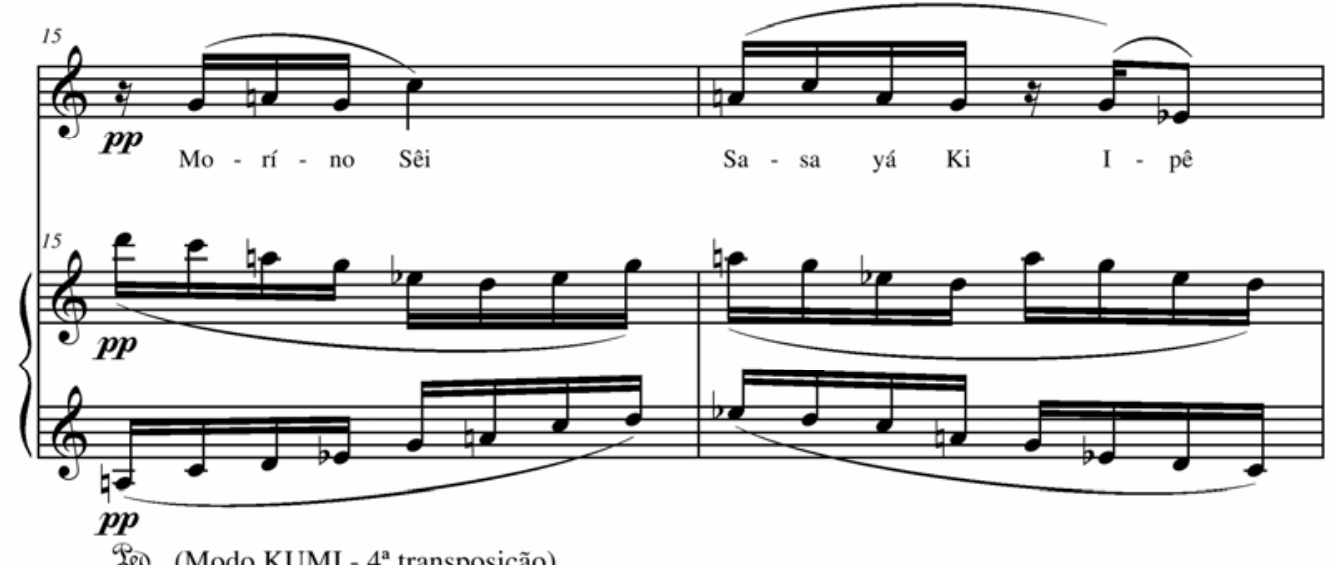

20o. (Modo KUMI - $4^{\mathrm{a}}$ transposição)

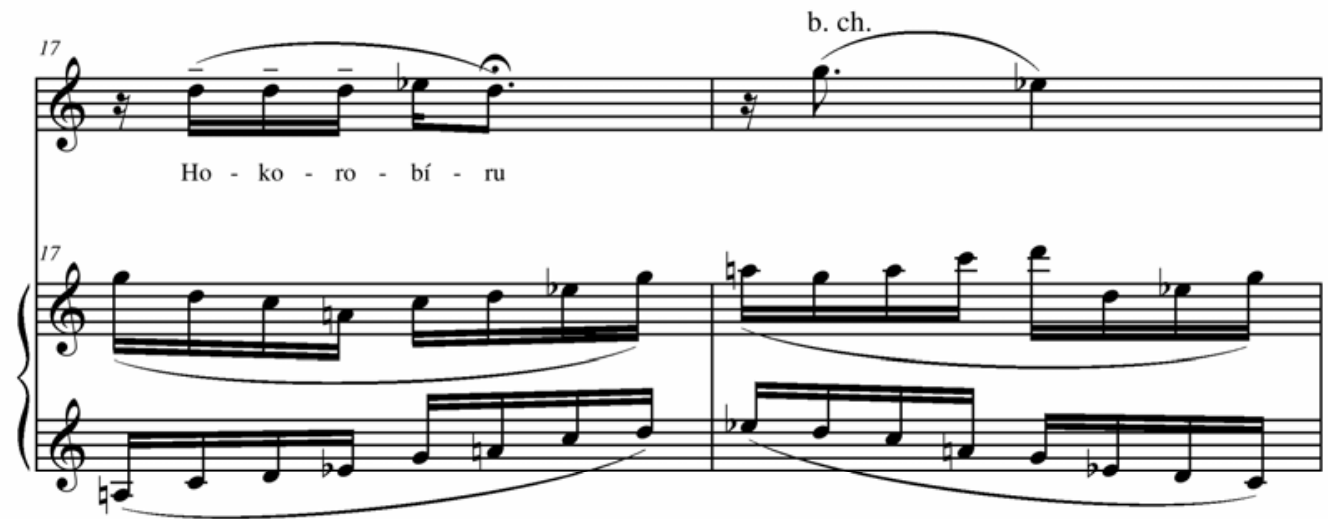




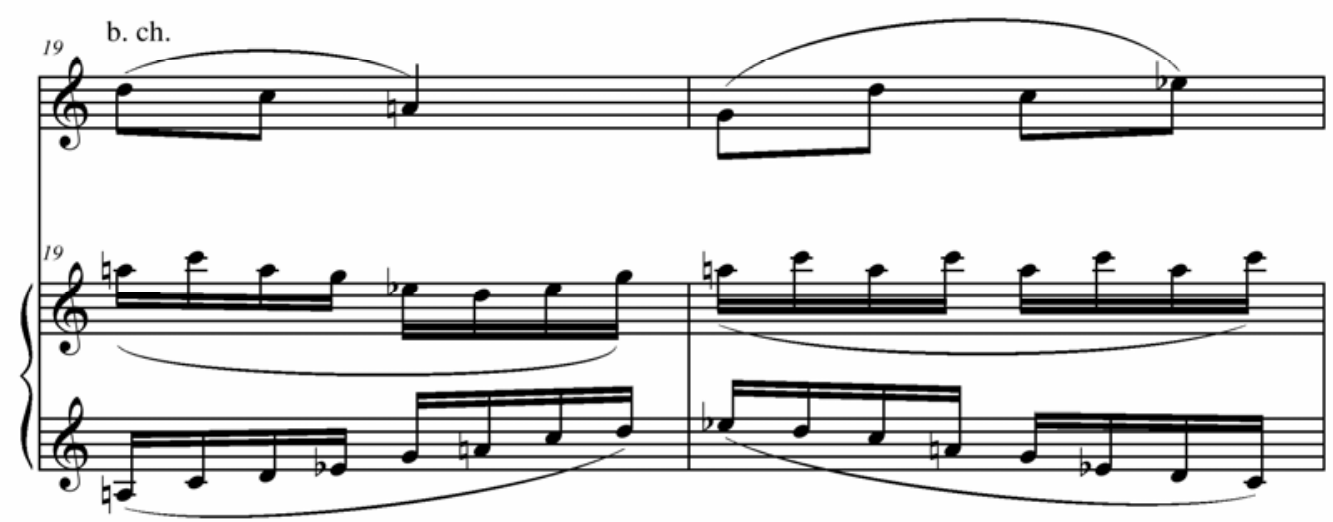

(b. ch.)
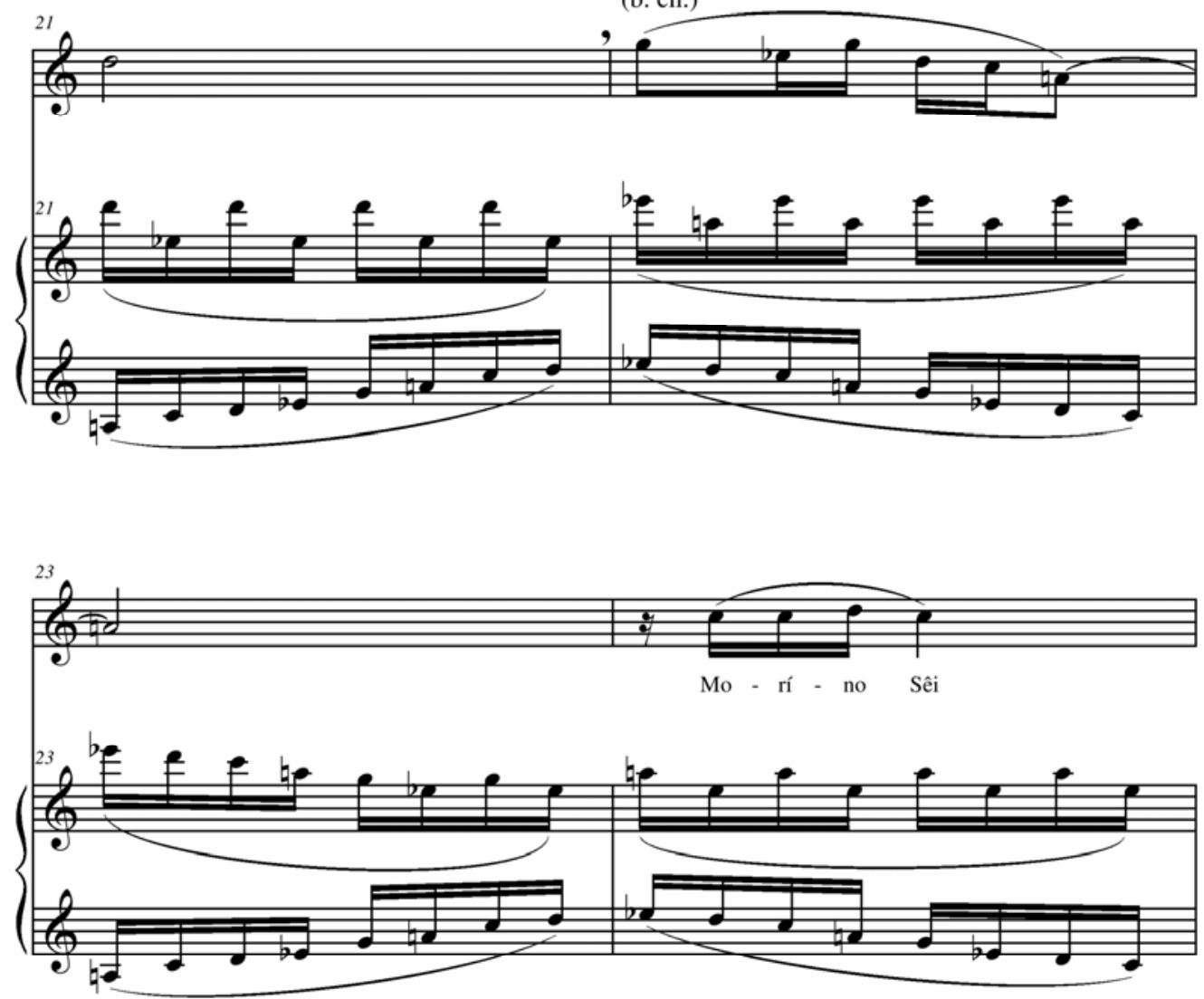

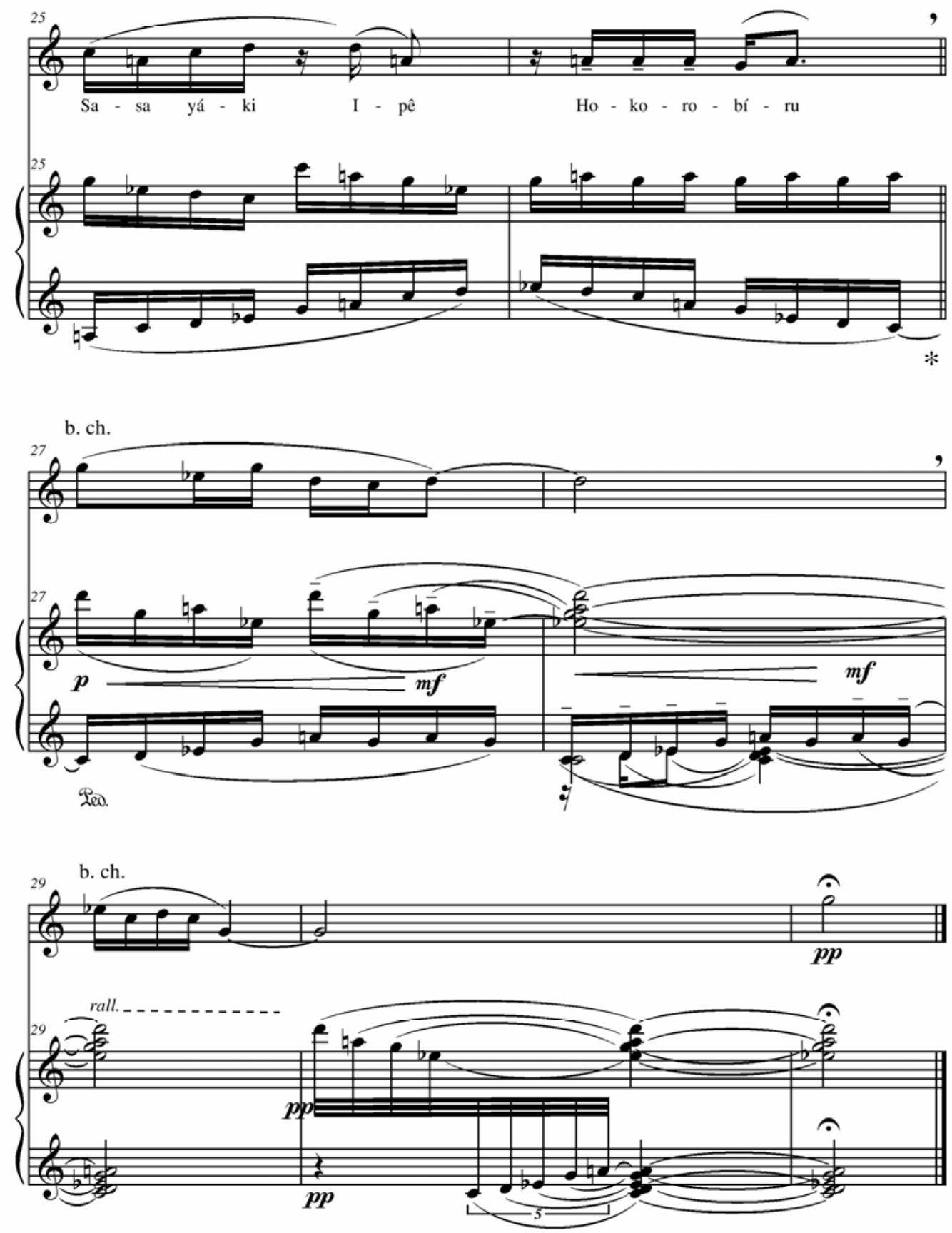